FISCAL FEDERALISM IN SOUTH AFRICA

JOACHIM HANS-GEORG WEHNER

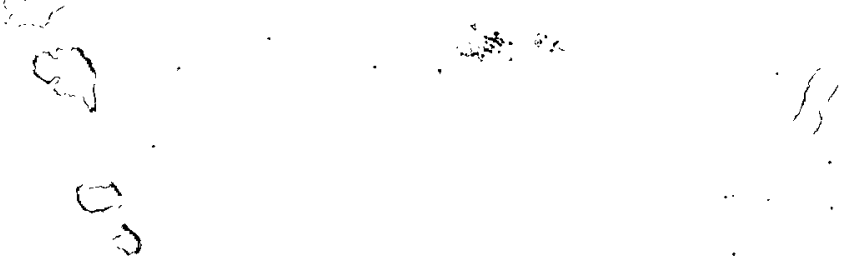




\title{
FISCAL FEDERALISM IN SOUTH AFRICA
}

\author{
JOACHIM HANS-GEORG WEHNER
}

Thesis presented in partial fulfilment of the requirements for the degree of Master of Arts at the University of Stellenbosch

\author{
Supervised by \\ Professor Hennie Kotzé \\ Department of Political Science \\ University of Stellenbosch \\ South Africa \\ Professor Richard Simeon \\ Department of Political Science \\ University of Toronto \\ Canada
}

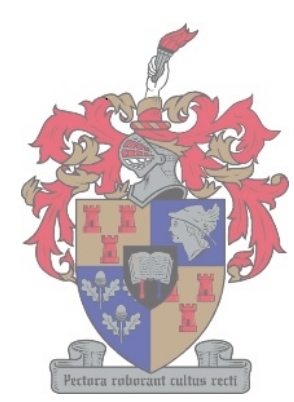

December 1999 


\section{DECLARATION}

I, the undersigned, hereby declare that the work contained in this thesis is my own original work and that I have not previously in its entirety or in part submitted it at any university for a degree.

Joachim Hans-Georg Wehner

Date: 3 August 1999

\section{VERKLARING}

$\mathrm{Ek}$, die ondergetekende, verklaar hiermee dat die werk in hierdie tesis vervat, my eie oorspronklike werk is en dat ek dit nie vantevore in die geheel of gedeeltelik by enige universiteit ter verkryging van 'n graad voorgelê het nie.

Joachim Hans-Georg Wehner

Datum: 3 Augustus 1999 


\section{ABSTRACT}

This thesis captures the assignment of functions and resources to the national, provincial and local spheres of government in South Africa, and provides an assessment of the functionality of this assignment. The perspective of fiscal federalism is used as the analytical tool for this assessment. The discussion, in the second chapter, of considerations in the design of fiscal federalism generates the conceptual reference frameworks necessary for the assessment of the South African system. It also outlines the impact of constitutional provisions on fiscal arrangements in a country, an aspect that is further explored in the third chapter. This chapter highlights some of the key choices, relating to fiscal design, that negotiators were faced with during the deliberations on the new South African Constitution. A detailed analysis of fiscal federalism in South Africa follows in the fourth chapter. The fifth chapter concludes that there is substantial congruence between the expenditure assignment recommended by economic theory and that outlined in the South African Constitution of 1996. Revenue assignment, on the other hand, remains centralised although the theoretical framework indicates a number of sources suitable for decentralisation. While the South African Constitution allows for provincial taxation powers, these have yet to be implemented. The analysis indicates that further developments of the system of intergovernmental transfers and grants should be concerned with ensuring revenue adequacy for all spheres, providing incentives for sound financial management, and maximising predictability. The conclusion also argues in $\mathrm{fa}_{-}$ vour of activating the constitutional borrowing powers of provinces to enable a greater focus on developmental expenditures. Corruption and a lack of administrative capacity in some subnational authorities, national mandates imposed on provinces without detailed costing and impact analysis, and rising provincial personnel costs all impede the smooth running of decentralised government in South Africa. Nevertheless, economic theory indicates that the constitutional assignment of responsibilities and resources to the different spheres in South Africa should not be adjusted for the sake of greater efficiency. Instead, the challenge remains to implement the system fully and to manage transitional difficulties proactively. Decentralisation includes a learning process, and newly created structures and institutions need to be developed and strengthened before they can deliver the full benefits of decentralisation. 


\section{OPSOMMING}

Hierdie tesis analiseer die toedeling van funksies en hulpbronne aan die nasionale, provinsiale en plaaslike sfere van regering in Suid-Afrika. Die bespreking van die oorwegings in die ontwerp van fiskale federalisme in hoofstuk twee genereer die nodige konseptuele verwysingsraamwerke vir die waardering van die Suid-Afrikaanse sisteem. Hierdie hoofstuk oorweeg ook die impak van grondwetlike bepalings op fiskale reëlings, 'n aspek wat verder verken word in die derde hoofstuk. Hierdie hoofstuk bring van die sleutel besluite na vore waardeur die onderhandelaars gekonfrontreer is tydens die beraadslaging oor die nuwe Suid-Afrikaanse grondwet. 'n Gedetaileerde analise van fiskale federalisme in Suid-Afrika volg in die vierde hoofstuk. Die vyfde hoofstuk kom tot die gevolgtrekking dat daar wesentlike kongruensie is tussen die toedeling van funksies soos omskryf in ekonomiese teorie en die Suid-Afrikaanse grondwet van 1996. Die toedeling van inkomste, daarenteen, is gesentraliseerd selfs al wys die teoretiese raamwerk op heelparty inkomstebronne wat gepas is vir desentralisasie. Terwyl die SuidAfrikaanse grondwet voorsiening maak vir provinsiale belastingsmagte, moet daar nog hiervoor voorsiening gemaak word deur wetgewing. Die analise dui aan dat verdere ontwikkeling van die sisteem van tussen regeringsoordragte en -toewysings voorsiening moet maak vir inkomstetoereikendheid vir alle sfere, aansporings moet voorsien vir betroubare finansiele bestuur, en voorspelbaarheid moet maksimaliseer. Die slotsom argumenteer ook ten gunste van die aktivering van grondwetlike leenmagte van provinsies ten einde 'n groter fokus op ontwikkelings-uitgawes moontlik te maak. Korrupsie en die afwesigheid van administratiewe kapasiteit in sekere subnasionale owerhede, nasionale verpligtings wat aan provinsies opgedring word sonder gedetaileerde kosteberekening en uitwerkingsanalise, en die groei in provinsiale personneeluitgawes belemmer almal die gladde funksionering van gedesentraliseerde regering in Suid-Afrika. Desnieteenstaande dui ekonomiese teorie aan dat die konstitusionele toedeling van verantwoordelikhede en hulpbronne aan die verskillende sfere in Suid-Afrika nie verander behoort te word ten gunste van groter effektiwiteit nie. Die uitdaging is eerder om die sisteem ten volle te implimenteer en om oorgangprobleme proaktief te bestuur. Desentralisasie sluit 'n leerproses in en nuut-geskepde strukture en instellings moet ontwikkel en vesterk word sodat hulle die volle voordele van desentralisasie kan lewer. 


\section{For Penelope}




\section{ACKNOWLEDGEMENTS}

The research for this thesis would not have been possible, in this form, without support from several organisations. I am indebted to the Applied Fiscal Research Centre (AFReC) at the University of Cape Town for supporting my research efforts over the past two years. Similarly, I have benefited from my association, since May 1997, with the Budget Information Service at the Institute for Democracy in South Africa (Idasa). The Financial and Fiscal Commission (FFC) kindly hosted me during a visit to Gauteng in April 1999. I wish to thank: Tania Ajam for raising my interest in the topic; John Stuart for ensuring that I was able to explore some initial ideas related to this thesis in three discussion papers written for AFReC; my supervisors Prof. Hennie Kotzé and Prof. Richard Simeon for their encouragement and guidance; and Albert van Zyl for comments, proofreading, the translation of the abstract into Afrikaans, and supplying valuable materials. 


\section{TABLE OF CONTENTS}

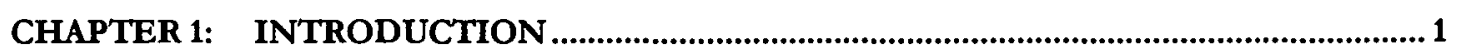

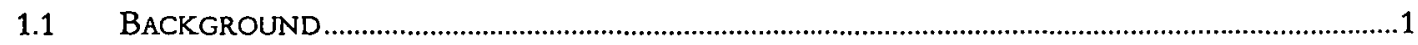

1.2 RESEARCH PROBLEM.......................................................................................................

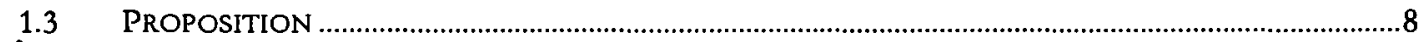

(1.4 DEFINING FISCAL FEDERALISM..............................................................................................

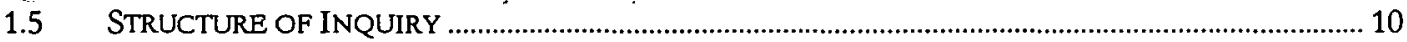

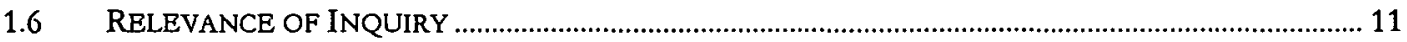

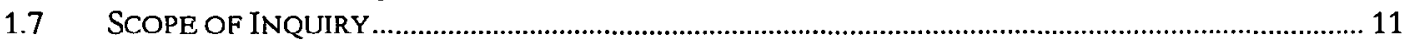

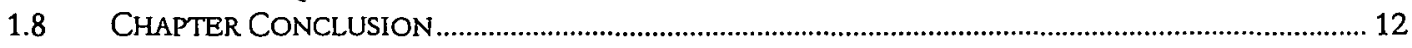

CHAPTER 2: CONSIDERATIONS IN THE DESIGN OF FISCAL FEDERALISM................13

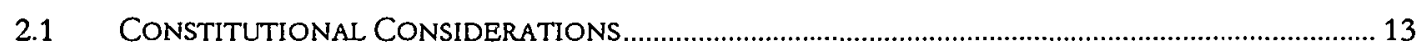

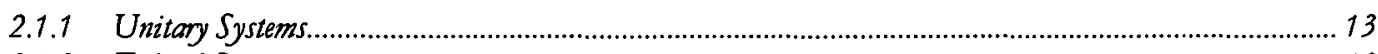

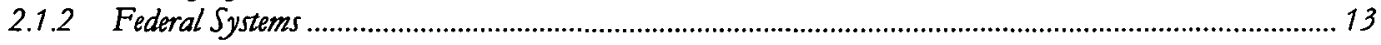

2.1.2.1 Political Rationales for Regional Government ................................................................ 14

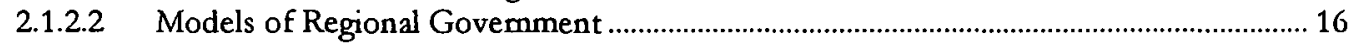

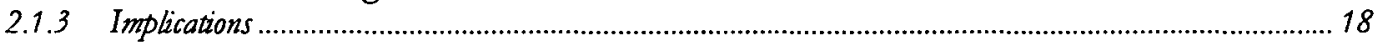

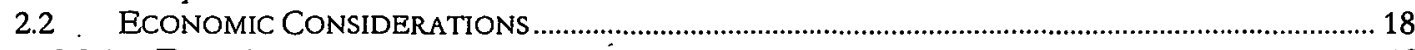

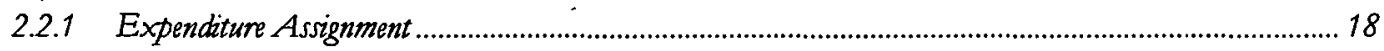

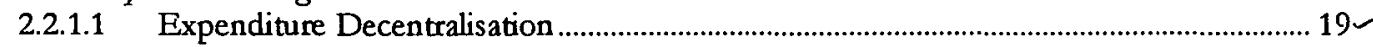

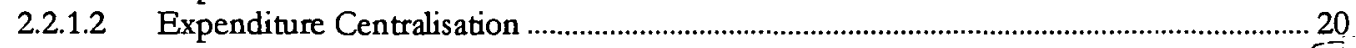

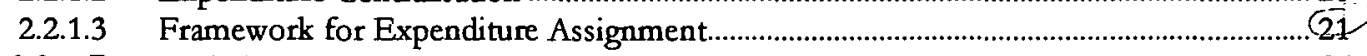

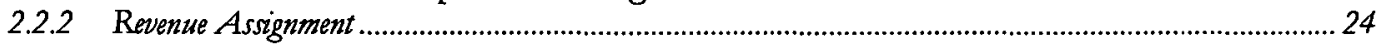

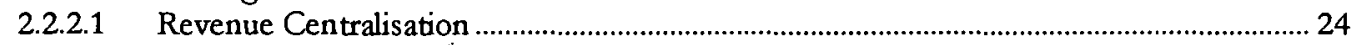

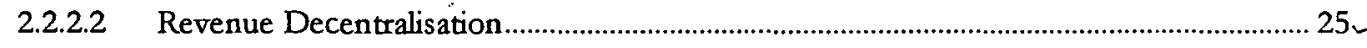

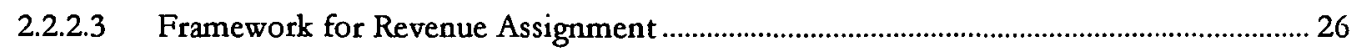

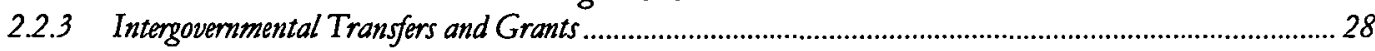

2.2.3.1 The Need for Transfers and Grants ............................................................................ 28

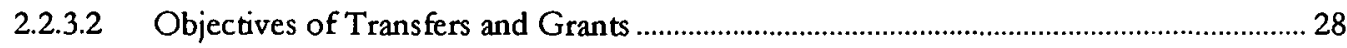

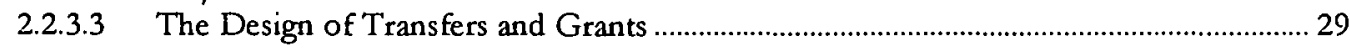

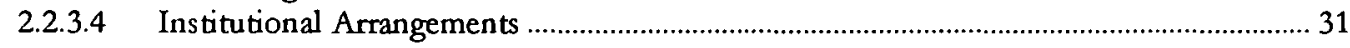

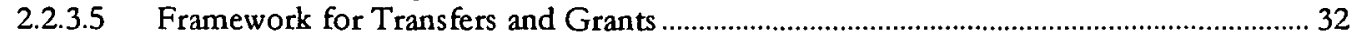

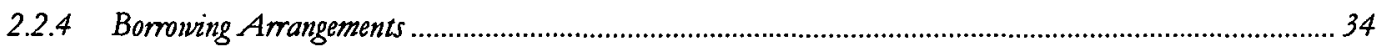

2.2.4.1 The Need for Subnational Govemment Borrowing ....................................................... 34

2.2.4.2 Possible Approaches to Subnational Government Borrowing .......................................... 34

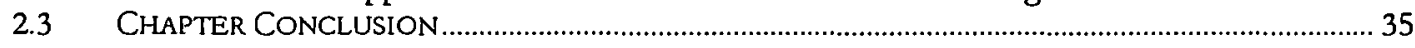

CHAPTER 3: FISCAL FEDERALISM IN COMPARATIVE PERSPECTIVE ....................... 36

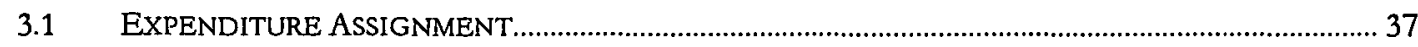

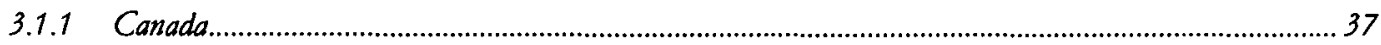

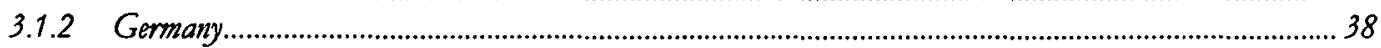

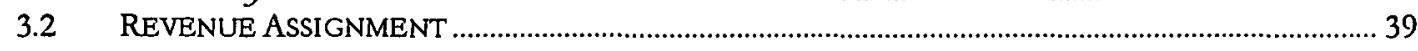

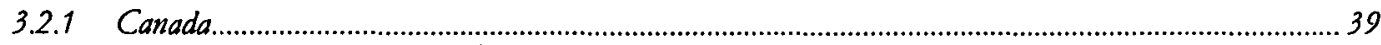

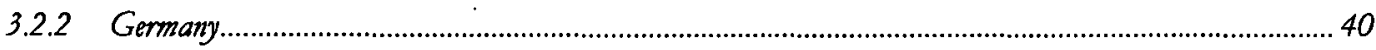

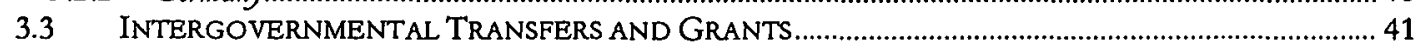

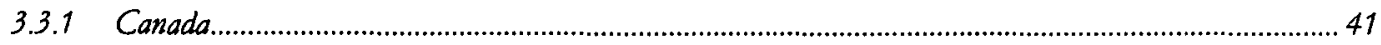

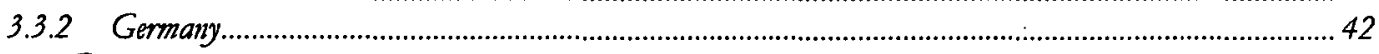

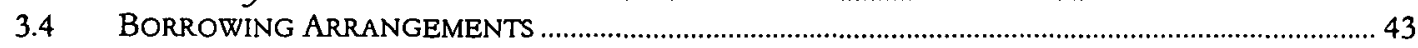

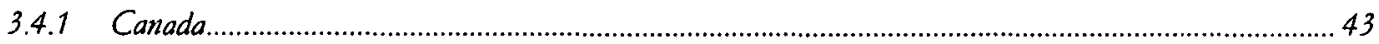

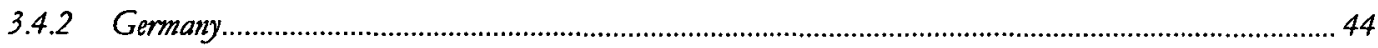

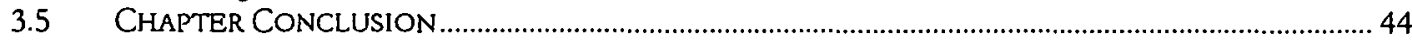


CHAPTER 4: FISCAL FEDERALISM IN SOUTH AFRICA ................................................. 46

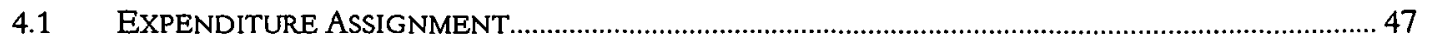

4.1.1 Assignment of Legislative Powers................................................................................................... 48

4.1.1.1 National, Provincial and Local Legislative Powers ........................................................... 48

4.1.1.2 Conflict Between Legislation ........................................................................................... 49

4.1.1.3 Provincial Participation in the National Law-Making Process .......................................... 50

4.1.2 Assignment of Executive Responsibilities ...........................................................................................5 52

4.1.2.1 National, Provincial and Local Executive Responsibilities .............................................. 52

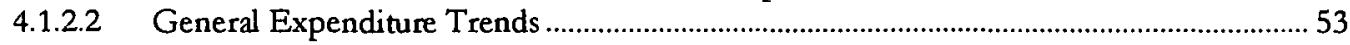

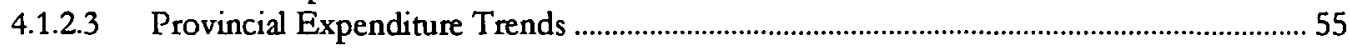

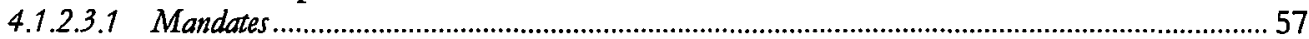

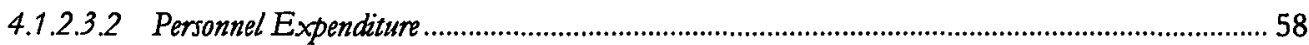

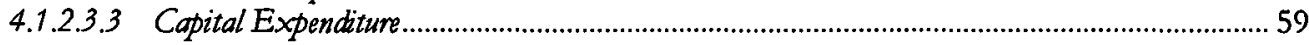

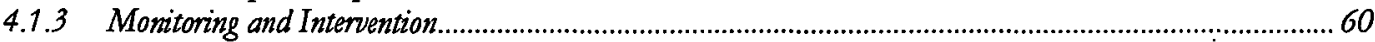

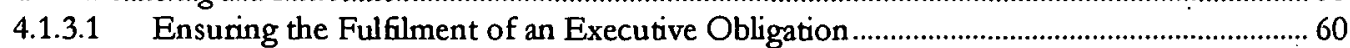

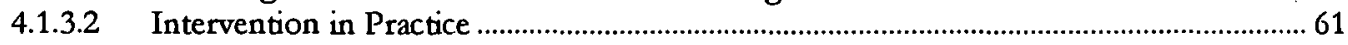

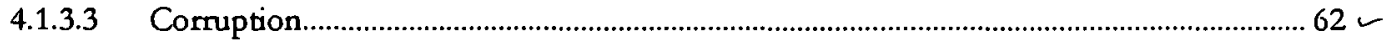

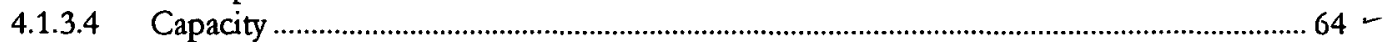

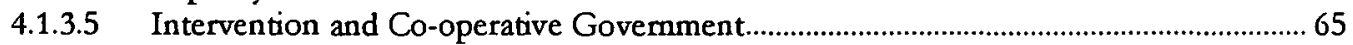

4.1.4 The Controversy Surrounding the Assignment of the Welfare Function ...................................................66

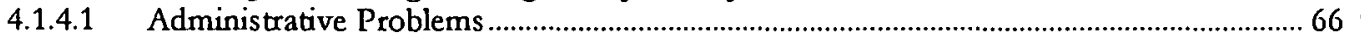

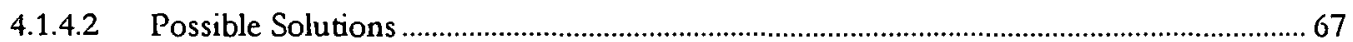

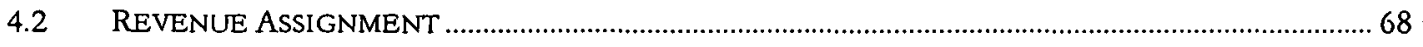

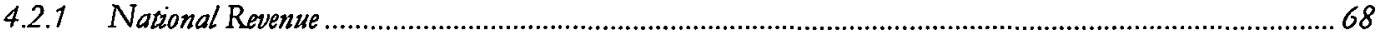

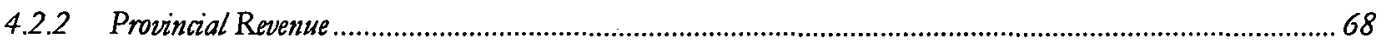

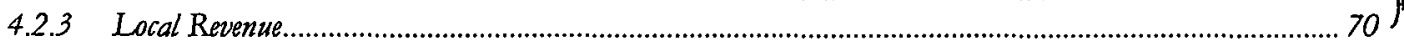

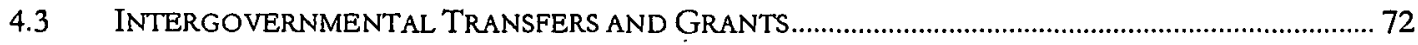

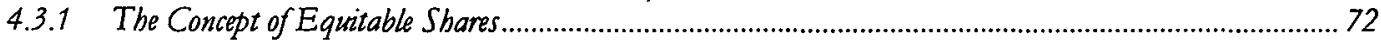

4.3.1.1 The Role of the Financial and Fiscal Commission ......................................................... 73

4.3.1.2 The Role of the National Council of Provinces................................................................... 73

4.3.1.3 The Role of the Budget Council .......................................................................................... 74

4.3.2 The Recommendations by the Financial and Fiscal Commission ........................................................... 74

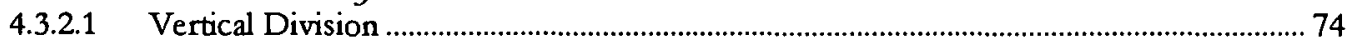

4.3.2.2 Provincial Equitable Share and Conditional Grants...................................................... 75

4.3.2.3 Local Govemment Equitable Share and Conditional Grants........................................... 78

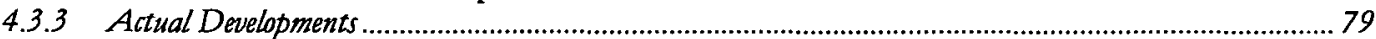

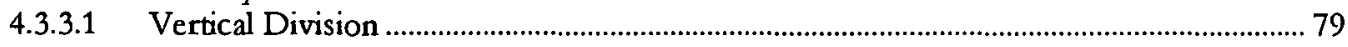

4.3.3.2 Provincial Equitable Share and Conditional Grants....................................................... 82

4.3.3.3 Local Government Equitable Share and Conditional Grants.......................................... 8 87

4.3.4 Review of Recommendations and Practices.......................................................................................... 88

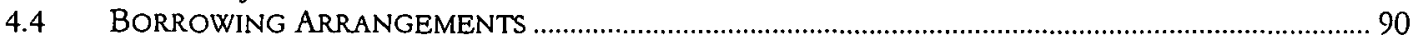

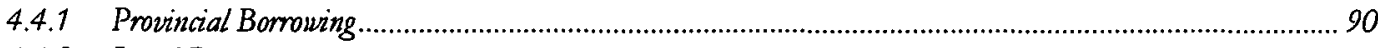

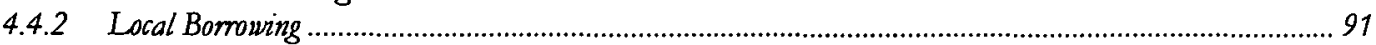

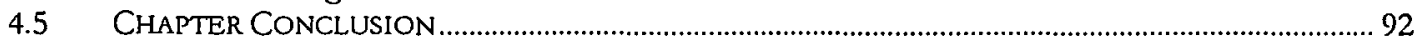

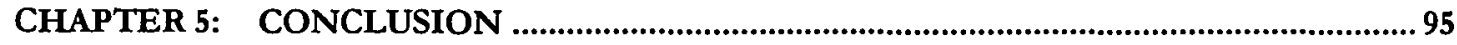

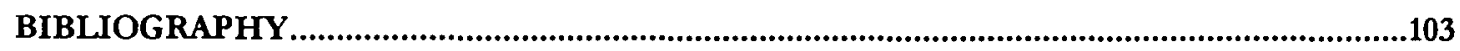

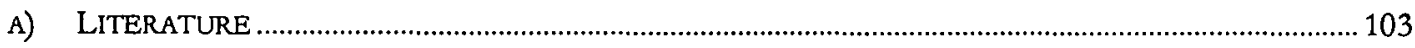

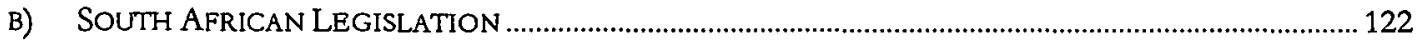

C) JUDGEMENTS OF THE CONSTITUTIONAL COURT OF SOUTH AFRICA ........................................... 122

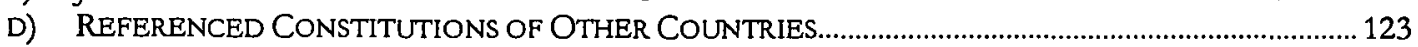

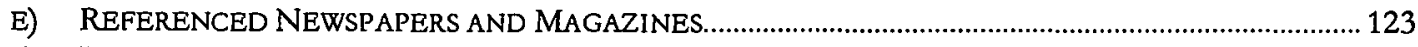

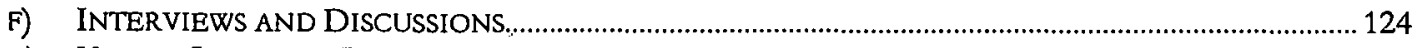

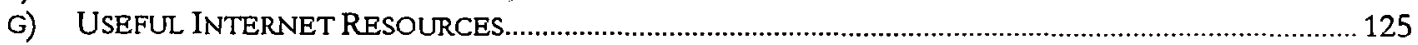




\section{LIST OF TABLES}

Table 1: Theoretical Framework for Expenditure Assignment ................................................................... 23

Table 2: Distribution of Govemment Expenditure in Selected Countries.................................................... 23

Table 3: Theoretical Framework for Revenue Assignment.............................................................................2 27

Table 4: Distribution of Tax Revenue in Selected Countries....................................................................27

Table 5: Theoretical Framework for Intergovernmental Transfers and Grants .......................................... 33

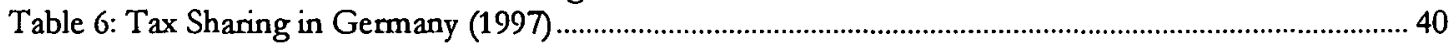

Table 7: Major Federal Transfers to Provinces in Canada (1997-8) .......................................................... 42

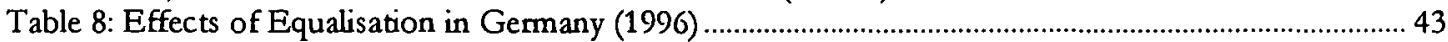

Table 9: Models of Regional Govemment and their Fiscal Arrangements ...............................................45

Table 10: Constitutional Assignment of Legislative and Executive Powers in South Africa ......................... 47

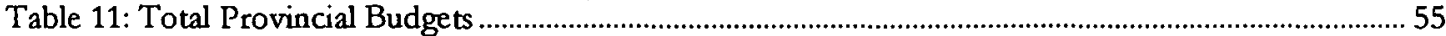

Table 12: Budgeted Provincial Capital and Personnel Expenditure ...........................................................6 60

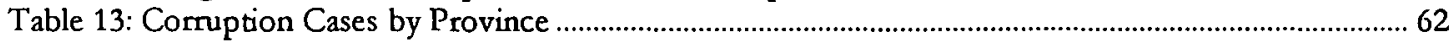

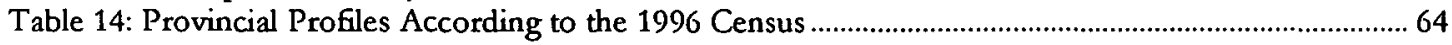

Table 16: Recommended Vertical Division of Nationally Collected Revenues, plus Provincial Revenues

from a Surcharge on the Personal Income Tax Base, Phased in from 1 per cent to 7 per cent............ 75

Table 17: Recommended Vertical Division of Nationally Collected Revenues, plus Provincial Revenues

from a Surcharge on the Personal Income Tax Base, Phased in from 1 per cent to 7 per cent............ 75

Table 18: Recommended Total Allocation per Province............................................................................ 77

Table 19: Recommended Total Formula Allocátion per Province ................................................................ 77

Table 20: Recommended Total Grants per Province per Capita ................................................................... 78

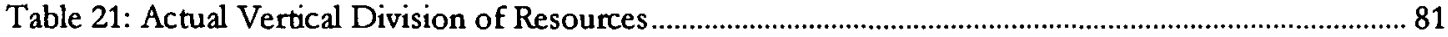

Table 22: Budgeted Transfers to Provinces for 1996-7 and 1997-8 ........................................................ 82

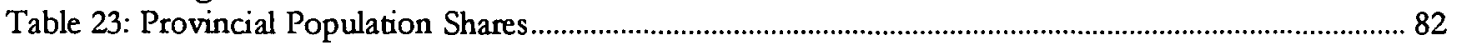

Table 24: Actual Formula for the Distribution of the Provincial Equitable Share .....................................8 83

Table 25: Conditional Grants to Provinces ............................................................................................. 87

Table 26: Consolidated Provincial Revenue and Expenditure ................................................................... 93

Table 27: Composition of Consolidated Provincial Revenue and Expenditure ............................................ 93

Table 28: Local Government Revenue and Expenditure ........................................................................... 94

Table 29: Composition of Local Government Revenue and Expenditure..................................................... 94

Table 30: Expenditure Assignment in Theory and in South Africa.............................................................. 96

Table 31: Revenue Assignment in Theory and in South Africa ................................................................. 98

Table 32: Proposed Rating of Intergovernmental Transfers and Grants in South Africa ............................ 99

\section{LIST OF FIGURES}

Figure 1: Regional Fiscal Dependency in Selected Countries ...................................................................... 33

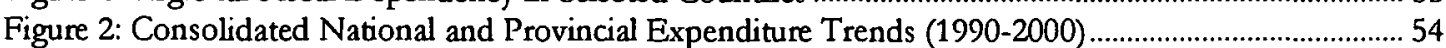

Figure 3: Consolidated Provincial Expenditure Trends (1995-2001) ............................................................... 56

Figure 4: Social Spending in 1999-0 Provincial Budgets ............................................................................... 56

Figure 5: Provincial Allocations from Nationally Collected Revenue (1995-1999)...................................... 81 


\section{CHAPTER 1: \\ INTRODUCTION}

\subsection{Background}

A world-wide trend towards fiscal decentralisation ${ }^{1}$ has emerged over the past decades. This development has not only occurred in federal countries, but also in unitary states with a previous record of centralisation (Ter-Minassian 1997a, Tanzi 1996: 296-297). ${ }^{2}$

In South Africa, there is a history of dispute over decentralisation. The 1910 Union of South Africa was negotiated in the aftermath of the Anglo-Boer war. Representatives from the former independent Boer republics demanded substantial autonomy for provincial structures, while delegates from the two British colonies argued for a strong central government. ${ }^{3}$ For much of this century, the four provinces ${ }^{4}$ on the territory of white South Africa acted mainly as administrative extensions of the national government. The constitutionally weak status of these entities was underlined when the Provincial Government Act (1986) replaced elected provincial legislatures with executive authorities appointed by the state president and headed by an administrator (Dollery 1998: 129).

The National Party (NP) government, which came to power in 1948, introduced the philosophy of apartheid. State partition became the declared aim as its policies unfolded. The nationalists pursued the regional concentration of the black majority, based on a series of consolidation plans. Land set aside for blacks was developed into a system of ten "homelands" along ethnic lines in the 1970s. Of these structures the Transkei, Bophut-

\footnotetext{
${ }^{1}$ Decentralisation describes a shift of functional responsibilities and / or resources to lower levels of govemment. Wolman (1990: 37) notes four operational definitions: (1) the range and importance of functions performed by subnational governments, (2) the autonomy given to subnational units through the legal relationship between national and subnational govemment, (3) the extent to which subnational governments are able to capture public sector resources, and (4) the degree of dependence of subnational governments on national government finance. Summary indicators, made up of all four elements, are most comprehensive as the definitions Wolman offers also reflect different aspects of decentralisation.

2 While in a unitary state ultimate political control rests with the central govemment, a federal state is based on the (usually constitutional) assignment of powers to different levels of govemment. The distinction will be discussed further in the second chapter.

${ }^{3}$ For the purpose of this analysis, the terms "provinces", "states" and "Länder" all describe governments at a regional level, between national and local government, since such regional authorities are named differently across countries. Throughout the text, the term "subnational govemments" is used as a summary term describing all governments within a country other than the central, federal or national government, whichever of the latter names is applicable in a given case.

${ }^{4}$ Namely the Cape Province, the Free State, Natal and Transvaal.
} 
hatswana, Venda and the Ciskei (the so-called "TBVC states") were given "independence" that was not recognised beyond South Africa. Under an elaborate resettlement scheme, an estimated 1.7 million people were displaced between 1960 and 1983 alone to "whiten" the territory of the republic, comprising all areas that did not form part of the homeland territories. The numbers of those "removed" from the white republic under resettlement programmes were swollen by those who were displaced from the urban areas under various influx control measures and forced to move to the homelands (Christopher 1994: 65-102).

The constitutional negotiations in the early 1990s signalled the end of this system of apartheid, and sought to achieve a peaceful transition to democracy and majority rule (De Villiers 1994a). One fundamental question that had to be addressed was what form of state the future South Africa should have, unitary or federal.

Party positions on the question of federalism in the initial negotiating forum, the Convention for a Democratic South Africa (CODESA), varied greatly. The governing NP, which had previously centralised the apartheid state by scrapping elected provincial legislatures, reversed to a decentralised strategy hoping to retain some political power at subnational level. The regionally-based Inkatha Freedom Party (IFP), too, was a strong supporter of federalism (e.g. IFP et al 1993). ${ }^{5}$ The liberation alliance of the African National Congress (ANC), to the contrary, feared that autonomous provinces would decrease its ability to govern, entrench existing disparities and could form the basis for divisive tribal politics. The party supported provinces as a vehicle for greater participation in democratic and developmental processes, rather than opposing centres of political power (Besdziek 1998).

The interim Constitution ${ }^{6}$ of 1993 reflected the compromises reached during the initial rounds of negotiations. ${ }^{7}$ Its schedule 4 contained 34 constitutional principles which pro-

\footnotetext{
${ }^{5}$ Although the IFP boycotted much of the negotiating process, the party ended up participating in the founding elections at the eleventh hour. The party's recently proposed constitutional amendments seek to, inter atia, increase provincial autonomy (IFP 1998). The IFP proposes eliminating perceived constraints hindering policy formulation by provinces, giving provinces the power to settle boundary disputes, strengthening the role of provincial constitutions, and extending exclusive provincial powers to such areas as policing, land affairs, ports and harbours.

"In the following analysis Act 108 of 1996 is referred to as "the Constitution", or as the "new" or "final Constitution", as distinct to the so-called "interim Constitution" (Act 200 of 1993) which governed the country for a transitional period of three years.

7 For a description of South Africa's "negotiated revolution", see Sparks (1994).
} 
vided a set of constraints and guidelines for the writers of the final Constitution. The interim Constitution empowered a Constitutional Assembly, consisting of both houses of a democratically elected Parliament, to draw up a final Constitution for the country (section 68). With regard to the structures, functions and powers of provinces, this assembly would be informed by a Commission on Provincial Government (sections 163 and 164).

A return to a system with four provinces, now incorporating the former homeland territories, had little support. The NP and the ANC both focused on the nine "development regions" outlined by the Development Bank of South Africa (DBSA) in 1982 as the basis for demarcation proposals (Welsh 1994, Urban Foundation 1993, McCarthy 1993). The territorial boundaries of today's nine provinces - the Eastern Cape, Free State, Gauteng, KwaZulu-Natal, Mpumalanga, Northern Cape, Northern Province, North West and the Western Cape - in essence resemble this demarcation. ${ }^{8}$ All homeland structures were abolished and incorporated into these nine provinces. Several border disputes remain?, but the demarcation has not been challenged in any fundamental way.

The first democratic elections for the national Parliament and nine provincial legislatures were held on 27-29 April 1994 (Lodge 1995, Mattes 1995, Souṭhall 1994). Local government elections were held as from November 1995 (Lodge 1999: 40-55, Randall 1998). In 1994 the ANC won 252 out of 400 seats in the National Assembly, a majority of 63 per cent. The party also gained the most votes in seven of the nine provinces, obtaining its best result in the Northem Province with a 92 per cent share of the provincial vote. The NP won in the Western Cape with 53 per cent of the vote, while the IFP gained a narrow 50 per cent majority in KwaZulu-Natal, a province that was and continues to be plagued by high levels of conflict (Cherry 1994). ${ }^{10}$

\footnotetext{
${ }^{8}$ In summary, the former Transvaal was broken up into four separate entities (Gauteng, Mpumalanga, Northem Province and North West). The territory of the former Cape Province was divided into three new structures (Eastem Cape, Northern Cape and Westem Cape). The boundaries of the Free State and Natal were retained to some degree.

9 For example, the residents of Bushbuckridge in the Northem Province have been demanding incorporation into Mpumalanga (Griggs 1997).

${ }^{10}$ The electoral dominance of the ANC was consolidated in the second democratic elections held on 2 June 1999. The party gained 66 per cent of the national vote, translating into 266 out of 400 seats in the National Assembly, one seat short of a two-thirds majority. The ANC also won outright majorities in seven of the nine provinces, but fell short in KwaZulu-Natal and the Westem Cape, where no party gained a majority of votes (Business Day, 8 June 1999). Due to the hung legislatures in the Western Cape and KwaZulu-Natal, coalition governments became necessary at provincial level (Chothia 1998). The ANC attempted to counter the "provincialisation" of its party structures (Sindane 1997) by centralising the appointment of premiers in the ANC-govemed provinces for the 1999 elections (Business Day, 23 April 1999).
} 
A version of the new Constitution was adopted by the Constitutional Assembly on 8 May 1996. However, the Constitutional Court found that parts of the text did not comply with the constitutional principles contained in the interim Constitution. With regard to provinces, the court noted that their powers over policing, education, traditional leadership and local government had been substantially diminished. ${ }^{11}$ After its first certification judgement ${ }^{12}$, delivered on 6 September 1996, the text was referred back to the Constitutional Assembly. The assembly amended the text to comply with the court's requirements, and the final Constitution was adopted on 11 October 1996. It was subsequently approved by the Constitutional Court in its second certification judgement. ${ }^{13}$

The process of drafting the Constitution involved many South Africans through arguably the largest public participation programme ever carried out in South Africa. Two years of intensive consultations attempted to integrate, as far as possible, the views of ordinary citizens, civil society and political parties. It is not often that deep-rooted conflict in a society is successfully channelled through a constitution-making process (Banting and Simeon 1985). South Africa is an example of where this was the case.

The Constitution shapes the overall structure of government in the country, and captures the compromise over decentralised governance. Most notably, the founding provisions stipulate that the Republic of South Africa is "one sovereign democratic state" (section 1), rather than a grouping of independent territorial entities, for which the Constitution is the supreme law (section 2). However, the Constitution also prescribes that government be constituted as national, provincial and local "spheres of government", which are described as "distinctive, interdependent and interrelated" (section 40). The term spheres of government, rather than tiers or levels, has been interpreted as implying a nonhierarchical relationship and "some equality in status of national, provincial and local government" (Department of Constitutional Development 1999: 10). The Constitution accordingly provides for the unity of the country, while at the same time providing for provincial and local structures.

Different positions are often taken on the question of whether post-apartheid South Africa is a federal state or not. Some argue that it is a unitary state with some federal ar-

\footnotetext{
11 In the latter case the decrease of provincial powers was balanced out by increased local autonomy, which the court regarded as a positive advance.

12 Certification of the Constitution of the Republic of South Africa, 1996, 1996 (4) SA 744 (CO).
} 
rangements, or "a figleaf for federalism" (O'Malley 1994). Others call it a federal state (e.g. Kriek 1996 and 1994). The final Constitution does not use the terms "federal" or "unitary", nor did the interim Constitution. The concept of federalism is highly controversial in South Africa, because it is frequently associated with apartheid's homeland system and its deeply racist ideological justification. As a result, some people may reject the word "federalism", but be comfortable with terms such as "decentralised governance", "regionalism" or "provincial system". Southall (1994: 649) remarks that "there seems to be an unwritten agreement amongst politicians of all stripes and the media to avoid explicit use of that term [i.e. federalism]". Although this debate is interesting from a purely academic angle, it seems to have little practical relevance. As Tapscott (1998: 27) notes, labels such as "federal" and "unitary" are of less importance than the manner in which intergovernmental relations are structured and function in practice.

According to the final Constitution, provincial governments are now responsible for the administration of such vital areas as welfare, public health, primary and secondary educa-tion. In 1997, for the first time, the nine provinces that had been created in 1994 were responsible for drawing up their own budgets, within an overall resource envelope ${ }^{14}$, rather than managing centrally determined allocations for each spending area.

The structure of local government, too, has been subject to substantial revisions. ${ }^{15}$ The final Constitution requires a "wall-to-wall" system of local government, covering the entire territory of the country (section 151(1)). ${ }^{16}$ However, many local authorities, especially those that were newly created, have experienced great difficulty in fulfilling their functions (Solomon 1998). In a joint report on the state of municipal finance, the Departments of Constitutional Development and Finance (1997: 48) acknowledge that restruc-

\footnotetext{
${ }^{13}$ Certification of the Amended Text of the Constitution of the Republic of South Africa, 1996, 1997 (1) BCLR 1 (CC). 14 The term "resource envelope" describes the total amount of money that is available to cover the expenditure of a department, govemment, or level of government.

15 The Local Government Transition Act (1993) represented the first attempt to introduce a unified system for local government throughout the country. The end of apartheid left the country with a system that was fragmented along racial lines (Ismail and Mphaisha 1997: 3-9, Tapscott 1996: 13). Shack settlements had become a common feature in urban areas by the end of apartheid, due to a mixture of population growth, migration from rural areas, inadequate housing and government policy not to provide rented houses in the townships (Mashabela 1990). The task was to transform local govemment into viable entities capable of facilitating development (see: Reddy 1996, Simon 1996).

${ }^{16}$ Several pieces of legislation aim at the reorganisation of the local sphere. The Municipal Structures Act (1998) provided for the restructuring of the different categories and types of municipalities outlined in the Constitution (section 155), and the division of powers and functions between them. The Municipal Demarcation Act (1998) initiated a process of redrawing municipal boundaries in order to create more viable and sustainable structures. In addition, a Municipal Systems Bill and a Municipal Propenty Rating Bill are expected to be tabled in Parliament in the near future.
} 
turing has caused the newly formed municipalities to experience a dramatic increase in service responsibility, paired with an insignificant increase of the revenue base and extensive non-payment of municipal accounts.

Administrative problems are also being experienced at the provincial level. The previous Director-General of the Public Service, Paseka Ncholo, who was responsible for the "Provincial Review Report"17, called the administration in the provinces chaotic. He believed that provincial government "is not affordable and needs a rethink" (Business Day, 14 August 1997). ${ }^{18}$ A few months later, the Presidential Review Commission ${ }^{19}$ was reported to have recommended a take-over of the Eastern Cape by the national government in response to a breakdown of delivery structures in the province (Financial Mail, 1 May 1998).

The administrative ability of the provinces has been cast into doubt by a string of events. For instance, in January 1998 the Eastern Cape provincial government failed to pay pensions to about 632000 pensioners due to a lack of funds (Business Day, 9 January 1998). Soon afterwards the national government had to provide a "bailout" (in the form of an advance totalling R 1.5 billion) to the Eastern Cape and KwaZulu-Natal governments towards covering their budget deficits for the 1997-8 financial year ${ }^{20}$. At the beginning of 1999 pupils were left waiting for books and stationery in several provinces despite promises that study material would be delivered in time (Sowetan, 21 January 1999). Such events have brought disrepute to the provincial system, and comments such as the following are not uncommon: "It once saved bloodshed but now South Africa's constitution is wasting money" (Economist, 28 February 1998). This perception has led to calls from senior ANC politicians to take a fresh look at the structure of government in the country (e.g. Ramathodi 1998). The former Minister of Provincial Affairs and Constitutional Development, Valli Moosa, recommended a review of the constitutional powers of the three spheres of government in the interest of greater efficiency (Business Day, 20 May

\footnotetext{
17 Also known as the Ncholo Report (Ministry for the Public Service and Administration 1997).

${ }^{18}$ The report was based on a review of the administration of every department in the nine provinces. In roughly 350 structured interviews, over 950 provincial staff were asked for their views of how well they were performing their jobs.

19 The commission had been appointed by a presidential proclamation in April 1996, officially titled the "Commission of Inquiry Regarding the Transformation and Reform of the Public Service". Amongst its mandates was to conduct an intemal audit of each provincial administration, including planning, budgeting and financial execution (Presidential Review Commission 1998: 2). A widely respected academic, Vincent Maphai, was the chairperson of the commission.
} 
1999). President Thabo Mbeki, the successor of Nelson Mandela, has hinted that local government will soon receive greater attention (Sunday Independent, 23 May 1999). This would include the "deployment" of prominent ANC politicians to this sphere of government, in conjunction with a reallocation of resources. At a conference in March 1999 Mbeki (1999: 6-7) remarked:

"The proximity of our second democratic elections provides an opportunity for us to review the performance of the nine provinces we established in 1994. The future of the nine provinces has become a topic of public debate, with calls for changes to the structure and powers of the provincial sphere, and even the number of provinces. It is true that the establishment of nine provinces has brought government closer to the people, created more space for regional diversity and provided a mechanism for the implementation of national policies. At the same time serious concerns have been raised about the state of provincial governance, underscored by the instances of financial crisis and the failure of delivery institutions, which we have experienced during the last five years. The strength and weaknesses of the provinces highlighted by a number of reports and audits of provincial government should be dealt with in a forthright manner. We shall have to address such critical issues as: Rooting out corruption in all spheres of government; Addressing capacity deficiencies in our provinces; Reducing and containing personnel costs in our provincial budgets; Adopting alternative methods of service delivery, to reduce costs and improve the quality of service to the people."

\subsection{Research Problem}

South Africa's Constitution has assigned functions and resources to different spheres of government. At the same time it has been a challenge to ensure the smooth running of the new system, and calls for adjustments have been made. There is thus a need for an objective assessment of the functionality of the governmental structure in South Africa. The purposes of this study are: (1) to capture the assignment of functions and resources to the different spheres of government in South Africa and (2) to provide an assessment

${ }^{20} \mathrm{~A}$ financial year does not necessarily coincide with the calendar year, although it does so in many coun- 
of the functionality of this assignment. Such an assessment should indicate whether the constitutional assignment of functions and resources is to blame for the problems that have been encountered during the process of decentralisation, and whether adjustments to the assignment are necessary to achieve greater efficiency.

\subsection{Proposition}

This above discussion generates the following proposition: "The assignment of functions and resources to the different spheres of government in South Africa needs to be adjusted to achieve greater efficiency."

\subsection{Defining Fiscal Federalism}

The theory of fiscal federalism, or intergovernmental fiscal relations, provides guidance with regard to the assignment of expenditure functions and sources of revenue to various tiers in a decentralised system of government. ${ }^{21}$ This perspective, with its focus on functionality and efficiency, offers an analytical tool for the assessment intended in this thesis.

In a groundbreaking contribution building on the limited framework provided by Musgrave (1959: 179-183), Oates (1993: 17) describes the economic meaning of federal government as " $[a]$ public sector with both centralized and decentralized levels of decisionmaking in which choices made at each level concerning the provisions of public services are determined largely by the demands for these services of the residents of (and perhaps others who carry on activities in) the respective jurisdiction". Oates adds the following distinction: "In contrast to the conception of federalism in political science, it makes little difference to the economist whether or not decision-making at a particular level of government is based on delegated or constitutionally guaranteed authority." From this functional perspective, it is not important whether a particular system is federal from a constitutional perspec-

\footnotetext{
tries. The financial year in South Africa runs from 1 April until $31 \mathrm{March}$ of the following calendar year. 21 For this analysis the following definitions are employed, as put forward by the Intemational Monetary Fund (IMF 1997: 8), unless otherwise indicated: The term nevenue covers all non-repayable govemment receipts other than grants; grants are defined as unrequited, non-repayable, non-compulsory receipts from other govemments. I refer to transfers as payments to which the recipient is legally (often constitutionally) entitled. Often, however, the terms transfers and grants are used interchangeably in the literature.
} 
tive. Rather, economists tend to treat all governmental systems as federal in character, to varying extents, in the sense that budgetary decisions are made at different levels (Heyns 1995: 150, Shah 1994b: 910). ${ }^{22}$ Thus, fiscal federalism is studied across a range of constitutional systems (e.g. TerMinassian 1997a).

The theory of fiscal federalism is concerned with assigning expenditure functions and revenue sources to the economically appropriate level of government. Guiding principles are proposed to govern the assignment of expenditure functions (e.g. Ahmad et al 1997, Oates 1993: 31-63) as well as the assignment of revenue sources (e.g. Norregaard 1997, Spahn 1995, Oates 1993: 119-180). When resources do not match the assigned expenditure functions, imbalances can be addressed through intergovernmental transfers and grants (e.g. Ahmad and Craig 1997, Oates 1993: 65-118). Some guidance on borrowing arrangements has also been proposed (e.g. Ter-Minassian and Craig 1997).

However, while a certain fiscal design may be desirable according to economic theory, socio-political circumstances and constitutional provisions can limit the design options (Bird 1993). Bird and Chen (1998: 52) explain that jurisdictional boundaries and the assignment of functions and finances may often have been fixed at some earlier (e.g. constitutional) stage. The implication is that any policy recommendations concerning fiscal design should take the constitutional framework of a country into consideration (unless, of course, these parameters can easily be changed).

The literature on the practice of intergovernmental fiscal relations has grown substantially over the past years. Ter-Minassian (1997a) provides the most recent and comprehensive review of fiscal federalism in theory and practice. Unfortunately, the impressive collection of case studies does not include an analysis of the South African system. In fact, there are only a few examples of academic writing on South Africa's. new fiscal federalism. Acting as a consultant to. the World Bank during a mission to South Africa in 1993, McLure (1994) generated a basic set of recommendations. Heyns (1994) has offered an interesting conceptual discussion of equity and redistribution from a fiscal federalism perspective, with reference to the interim Constitution. Based on the text of the new Constitution and some initial developments, Abedian et al (1997) produced a first description of South Africa's emerging fiscal structures. More recently, Dollery (1998)

22 Exceptions may occur in geographically extremely small countries or "mini states". 
suggested an initial evaluation of South Africa's revenue-sharing arrangements under the current Constitution. While providing interesting and important snapshots, the rapid changes to the South African system have outdated substantial parts of these analyses. In addition, the work of the advisory Financial and Fiscal Commission (FFC) has contributed towards developing fiscal federal theory and practice within the South African context (FFC 1998a, 1997, 1996, 1995). The work of the commission will be dealt with in detail in the discussion of the South African system.

\subsection{Structure of Inquiry}

The second chapter reviews considerations in the design of fiscal federalism by exploring the various theoretical aspects pertaining to the assignment of functions and sources of revenue. The purpose of the chapter is to generate a reference framework for the description and assessment of the South African system.

The third chapter contains a comparison of two countries which served as prominent reference models for the structure of government during the constitutional negotiations in South Africa. The chapter tracks some of the key options that constitutional designers were faced with, and thcir impact on fiscal arrangements. Its purposes are to demonstrate the practical relevance of the theoretical considerations outlined in the previous chapter, and to provide a comparative context, from a fiscal perspective, for the description and analysis of the South African system.

The existing structures in South Africa are discussed in the fourth chapter. It draws mainly on the final Constitution and relevant legislation, budgetary data, and a discussion of suggested and actual practices. The purposes of this chapter are to provide an in-depth analysis of the South African system, enabling a comparison to the reference framework developed earlier, and to highlight key issues relating to its practical functioning.

The fifth chapter contains the conclusion. Its purposes are to summarise the main findings and to come to an assessment of the functionality of the South African system. Based on this analysis, the necessity of adjusting the current assignment of functions and resources will be investigated. 


\subsection{Relevance of Inquiry}

Actors outside government have not yet undertaken a comprehensive functional assessment of the structure of government in South Africa. This inquiry is aimed at contributing towards filling this research gap. In addition, political scientists have not yet thoroughly analysed South Africa's fiscal structures. This may partially be due to the fact that public finance is often regarded as a "technical" or "economics-driven" field, unsuitable for the analytical tools of the political scientist. On the other hand, political scientists are highly regarded contributors to the development of fiscal arrangements in many other countries. This inquiry is an attempt to bring the fiscal aspects of multi-level governance into the debate amongst political scientists over the future of the three-sphere system in South Africa.

\subsection{Scope of Inquiry}

Provincial government is at the centre of this analysis, since the purpose of local government as a separate sphere is generally not disputed. The analysis does, however, include local government, and refers to national government were contextually necessary. A comprehensive assessment of the role of provincial government requires an understanding of its interaction with the other spheres of government.

It is not the purpose of this analysis to provide a description of the constitutional negotiations. The negotiating phase has been captured elsewhere (e.g. Sparks 1994). Rather, the focus of this analysis is on the fiscal structures outlined in the new Constitution and developments that have taken place within these structures.

Due to the rapid changes to the South African system, this analysis is necessarily a snapshot. Apart from minor details, the research towards this thesis was concluded in June 1999. The analysis thus seeks to capture the relevant developments between the taking effect of the new Constitution as from 1997 and the second democratic elections. 


\subsection{Chapter Conclusion}

The negotiated transition to democracy brought with it a new structure of government for South Africa, consisting of the national, provincial and local spheres. The functionality of this new structure is increasingly being questioned, and calls for reform have been made. The inquiry sets out to capture the assignment of functions and resources to the different spheres of government in South Africa and to provide an assessment of the functionality of this assignment. The perspective of fiscal federalism focuses on the assignment of functions and resources within the context of a decentralised system of government. This perspective, with its focus on functionality and efficiency, offers an analytical tool for the intended assessment. The study draws on theoretical considerations, a comparative background, and an in-depth analysis of intergovernmental fiscal relations in South Africa. 


\section{CHAPTER 2:}

\section{CONSIDERATIONS IN THE DESIGN OF FISCAL FEDERALISM}

This chapter reviews considerations in the design of fiscal federalism by exploring the various theoretical aspects pertaining to the assignment of functions and sources of revenue. The purpose of the chapter is to generate a reference framework for the description and assessment of the South African system. The chapter discusses constitutional models which have a bearing on the design of fiscal structures, and the criteria provided by the theory of public finance.

\subsection{Constitutional Considerations}

The division of powers and functions to various levels of government varies across countries. With regard to the form of state, constitutions may be seen to fall into two broad categories (Kriek 1996).

\subsubsection{Unitary Systems}

In a unitary system of government, the effective overall control of all governmental functions rests with the central government (Shah 1994b: 5). Until the recently initiated process of decentralisation $^{23}$, the United Kingdom was a classic example of a unitary state (Kendle 1997). Other examples are France, Turkey and Japan. In a unitary system, the central government is free do decide which functions and resources are to be assigned to its regional and local administrative branches, and it can adjust this assignment at its discretion.

\subsubsection{Federal Systems}

In a federal system, decision-making is divided between levels of government usually based on a constitutional assignment of powers (Schultze 1996: 157, Nathan and Balmaceda 1990: 60). Federalism can enable a balance between unity and diversity by medi-

${ }^{23}$ Scotland and Wales have recently voted in favour of regional assembles which will regulate areas of local concern. In the case of Scotland the electorate also voted in favour of giving its assembly the power to tax (Daily Telegraph, 25 February 1998). Elections to the newly created assemblies took place in May 1999. 
ating between diverging ideas about the nature of political communities. Although this category is diverse, a common feature in these systems is the existence of elected regional governments in addition to national and local governments. ${ }^{24}$ Prominent examples of federal countries are Germany, Canada, the United States, Switzerland, India and Brazil. ${ }^{25}$ Unlike in unitary states, the constitutional division of powers in federal states makes it more difficult to affect adjustments to the fiscal structures, as this would require amendments to the constitution.

\subsubsection{Political Rationales for Regional Government}

The following are some central political rationales for regional government:

Enbancing Democracy. Every democratic order relies on the broad support of its citizens. The more interfaces a political system offers, the more opportunities to express preferences exist, and the greater the potential for overall satisfaction. In a federal state, the most common form of participation, voting, can be practised more frequently than in a state without regional governments. ${ }^{26}$ In other words, regional government offers more opportunities for participation. Although this does not automatically make participation more meaningful, it encourages a closer link between decision-makers and citizens, and

\footnotetext{
${ }^{24}$ The concept of federalism is "a classic example of concept overstretch" (Bulpitt 1996: 180), and there is a lack of a generally accepted definition (Vemey 1995: 81, Burgess and Gagnon 1993, Nathan and Balmaceda 1990: 59). Wheare (1946) identified only a handful of states that he claimed could be called federal. His work is based on a definition of federalism as a situation where the citizen is a citizen of two governments, a general and a regional one. Since then, some writers have emphasised that national and regional polities in a federal system are or should be equal (Elazar 1995 and 1991). In practice, however, regional governments are often regarded as middle tiers or levels of government, implying a hierarchy of governments covering the same geographical area. Nathan and Balmaceda (1990:60) conclude: "As we see it, the acid test of federalism is not whether the general and local government are co-equal. The test of whether a political system is federal is whether it has regional govemments with consequential [emphasis in the original] power." They suggest a framework for analysis to compare the role and character of elected regional govemments in contemporary federalism. This framework includes an assessment of (1) legal powers; (2) revenue powers; (3) functional-area authority and responsibilities; (4) the role of the regional governments in the affairs of the central govemment; (5) historical, social and cultural identification; and (6) the power of local units. Given the dispute over the definition of the term, and the variety of systems it is associated with, such a flexible framework seems adequate. While constitutions are important indicators, federalism can easily develop differently to constitutional intentions (Hodgins et al 1989).

${ }^{25}$ A third category may be confederal systems of government, where a central government acts as an agent for independent member units. Examples of this latter group are the European Union (EU) and the Commonwealth of Independent States (CIS) consisting of the former Soviet Republics. A number of regional structures for economic co-operation, such as the Southem African Development Community (SADC), also bear some characteristics of a confederation. For the purpose of this analysis, this option is regarded as an extreme form of federalism, although some authors consider it to be a separate, albeit less prominent, category (e.g. Shah 1994b: 6).
} 
helps to "bring government closer to the people". The empowerment aspect of regional government is based on the principle of subsidiarity, which prescribes that any community shall only fulfil those tasks that cannot be fulfilled equally well, or better, by a smaller constituent community (Isensee 1968).

Protecting Democracy. There is also a line of thought that presents regional government as a tool to prevent tyranny by means of "parcelling off" and, to an extent, fragmenting state power along a vertical axis (Laufer and Münch 1997: 24-25). This makes regional government especially attractive to countries emerging from authoritarian rule or dictatorship and facing the task of constitutional redesign, such as Spain after the death of Franco or Germany after the demise of Nazi rule.

Conflict Management. Especially in ethnically divided societies, regional government offers a chance to national minorities to gain a majority at subnational level. According to Horowitz (1991: 217), for instance, such representation at subnational level may ensure that minorities will not resort to extra-legal, violent and destabilising means to pursue their aims. Rather, the possibility to gain political majorities, at a subnational level, acts as an incentive to remain within the overall system. Federalism can therefore act as political glue to ethnically divided societies (Smith 1995). This was the idea behind propagating the "federal solution" in the context of decolonisation, albeit without success in many cases due to a complex set of factors (Kendle 1997: 123-149). ${ }^{27}$ The relationship between territoriality and ethnicity is pivotal for conflict to be managed through federal arrangements (Schultze 1995: 158). This requires that ethnic minorities be concentrated in specific regions, as for instance in Canada but unlike in the United States.

While it is recognised that regional government has the potential to achieve these goals, it is also recognised that federalism is Janus-headed, which means that its advantages may, under certain circumstances, turn into its disadvantages (Simeon 1998: 47, Laufer and Münch 1997: 28). For instance, federalism may contribute to a perception that the wishes of minority communities are valued over those of national majorities. If the overwhelm-

\footnotetext{
${ }^{26}$ This effect is weakened in cases where national and regional elections are held at the same time, as currently in South Africa, as national issues often dominate the regional election agenda. Regional elections tend to receive more attention when the regions have varying election dates.

${ }^{27}$ Notably, many post-colonial constitutions were based on the recommendations of foreign advisors and supposed experts in their frelds, rather than the result of an indigenous negotiating process. The latter, however, is important to promote ownership of the new dispensation, and to ensure that a constitution addresses the particular social and political needs of a country.
} 
ing wish of the majority were repeatedly frustrated and hindered by a small minority, this would be undemocratic. With regard to the ethnic management goal of regional government, the dilemma is that by giving institutional recognition to such cleavages, they may also be perpetuated and even augmented. This may ultimately reinforce centrifugal tendencies. As Simeon (1998: 50) concludes: "All regional and autonomist movements are a combination of 'we want out' and 'we want in'. The trick is to find the right balance."

\subsubsection{Models of Regional Government}

Constitutional arrangements in federal systems are diverse (Saunders 1995, Elazar 1991). One basic distinction is between divided (dual and competitive) systems on the one hand, and shared (integrated and co-operative) models of regional government on the other (Simeon 1998, Laufer and Münch 1997: 157, Schultze 1995: 160, Shah 1994b: 7).

In the divided model, the idea is that national and regional institutions should be as independent as possible. Responsibilities are assigned to national and regional governments according to policy areas such as health, education or defence. As far as possible, the responsibilities of government are divided into distinct lists and each is assigned to one specific tier. The aim is to create "watertight compartments" by eliminating overlapping responsibility. In practice, this means that if a government is responsible for health, it regulates and implements policy in this sector.

The shared model, on the other hand, integrates and unites governments at different levels by emphasising co-operation and joint functions. Responsibilities are assigned according to governmental functions such as regulation by means of legislation on the one hand, and implementation and administration on the other. This means that one level formulates policy and monitors implementation, usually the national level, while another is responsible for actual implementation.

Several factors may impact on the choice between these two basic options (De Villiers 1994b: 269-270):

Approach to Federation. The far-reaching separation of functions pursued by the divided model is most likely to emerge from a "bottom up" approach to federation, i.e. one in 
which formerly separate units come together for a limited purpose (e.g. United States, Canada). In such a case, the necessary infrastructure to provide essential services will already exist within member units, which logically limits the involvement that is required by the central government in many important areas such as policing, health and education. If certain functions are already provided satisfactory at subnational level, there is no reason to facilitate central involvement in these areas. The shared model, to the contrary, is most likely to emerge from a "top down" approach to federation, where regional units are assigned some of the functions which were previously exercised at the central level. The constitutional changes taking place in Spain since 1978 are one example of such a top down process towards federalism, involving a transfer of functions from the centre to the regions (Newton 1997: 120). In this case, the centre is likely to retain some influence over regional functions, drawing on its experience and infrastructure.

Increasing Complexity of Governmental Functions. The two models are also tied to the development of the modern welfare-oriented state. From a historical perspective, the general direction seems to be from dual (or divided) to co-operative (or shared) systems of regional government. De Villiers (1994b: 270) explains: "The practical circumstances associated with modern government brought the realization that the respective levels of government could not operate in isolation from each other... The consequence is a new style of government and a different culture of intergovernmental relations, based on cooperation, co-ordination, and interdependency."

Political Culture. It has been argued that the divided model is more compatible with the Anglo American majoritarian and competitive nature of politics, while the shared model is more compatible with the consensual and co-operative style of governance that is prevalent in the political systems of continental Europe (Schultze 1995: 159).

There may be a range of other political factors influencing the choice between the divided and shared models. As Simeon (1998: 58-59) points out, the choice between these two alternative models is based on trade-offs. The divided model seems to maximise regional autonomy. It also simplifies transparency by providing for undivided lines of accountability; accountability is clearly assigned to the different levels of government by avoiding shared responsibilities. Furthermore, the divided model seems to promote competitive and adversarial federalism. The shared model, on the other hand, seems to 
maximise harmony, consistency and consensual policy making. It also requires ongoing co-operation and interaction. Accordingly, the shared model may tend to display more inherent centralised tendencies than the divided model.

\subsubsection{Implications}

In a unitary system the central government has a rather free hand in the design of fiscal structures, which makes it easy to follow the economic considerations to be discussed below. Federal systems, however, circumscribe the power of the centre. Thus, the latter deserve special consideration in order to understand the particular limits federal constitutions impose on fiscal design. As constitutional redesign is likely to be a controversial and lengthy process (Banting and Simeon 1985), the implication is that policy recommendations relating to the design of fiscal structures have a better chance of being implemented when this is possible within an existing constitutional framework.

\subsection{Economic Considerations}

The theory of public finance offers some guidelines with respect to the assignment of revenue and expenditure responsibilities to various levels of government in a decentralised system. This section considers the theoretical frameworks for expenditure and revenue assignment, and intergovernmental transfers and grants. A brief discussion of borrowing arrangements - as a means of enhancing the total income derived from revenue, transfers and grants - is also provided.

\subsubsection{Expenditure Assignment}

The assignment of expenditure functions is guided by the "decentralisation theorem" put forward by Oates (1993: 31-63). The theorem proposes that each public service should be provided by the jurisdiction having control over the minimum geographic area that would internalise the benefits and costs of such provision. This rule is a rephrasing of the principle of subsidiarity. In other words, responsibilities should be assigned to the lowest level possible without compromising the effective provision of a service. 


\subsubsection{Expenditure Decentralisation}

It is argued that the local provision of goods and services has the following benefits (Shah 1994a: 3, Oates 1993: 11-13):

Local provision enbances efficiency by reflecting local needs. A centralised or uniform provision often results in a "one size fits all" provision that may not satisfy specific local needs. Since preferences vary between localities, government would be wasting resources on services that may not be desired by some communities. The local provision of services allows communities to set their individual priorities, and allocate resources accordingly. If mobility is not otherwise restricted, citizens can "vote with their feet" by comparing service packages between jurisdictions and choosing according to their preferences. The overall result would be a more efficient allocation of resources, as allocations match the various sets of local preferences. .

Local provision eliminates multiple layers of jurisdiction. If a service can be provided at a lower level of government, this eliminates the need to have a central administration with subnational branches. As a result the central government is able to focus its attention and resources on those areas that require its involvement. This argument gains in strength with increasing geographical size or population of a country. The larger a country in terms of size or population, the more complex governmental functions become, and the more difficult it will be to administer public affairs through one centrally steered administration with agencies in the various regions.

Decentralised decision-making results iï bealtby competition between authorities, which encourages innovations in the provision of public services. Innovative new programmes can be pioneered at the subnational level before they are implemented on a broader scale. Should such new programmes fail, it would be less costly than if they had been implemented on a nation-wide scale. Thus, while creating space for innovations, decentralised decision-making also limits possible financial losses due to policy failure. 


\subsubsection{Expenditure Centralisation}

Despite arguments in favour of decentralisation, centralisation is warranted when the following considerations apply (Ahmad et al 1997: 28, Shah 1994a: 4, Oates 1993: 4-11):

Imperfect mobility limits the possibility that citizens express their preferences by voting with their feet (i.e. moving between jurisdictions). As a result, the decentralised provision of services might not match local preferences.

Spatial externalities occur when the geographical boundaries of a jurisdiction diverge significantly from the geographical concentration of people who utilise its services. In the case of benefit spillovers, the authority may not realise that substantial benefits accrue to non-residents. This would result in the under-provision of such a service. The reverse is the case with cost spillovers, where the costs for a service can be "exported" to other jurisdictions. ${ }^{28}$ The rule is that where the benefits of a service are national in scope, it should be assigned to the national government. Most prominently, this is the case with defence and foreign affairs.

Economies of scale exist with regard to certain services. If a service cannot be provided in a cost effective manner by a local jurisdiction, this service should be assigned to the next higher level of government where this would be the case. The need to provide transportation services, water and sewerage in a metropolitan area, for example, may justify a two-tier system of local government (e.g. Ahmad 1996, Shah 1994b: 12-15).

Furthermore, there is general agreement that certain policy functions simply cannot be successfully managed by subnational governments (Ahmad et al 1997: 28-30). Macroeconomic stabilisation and monetary policies are instances where firm control and undivided actions are required (Gupta et al 1994). This is unlikely to be possible if these functions were assigned to various subnational actors. Effective redistribution is only possible through programmes that are national in scope. Finally, equalisation between jurisdictions requires centralisation (Ladd and Yinger 1994, Bramley 1990).

\footnotetext{
${ }^{28}$ For example, if a local authority closed health clinics for the poor, they may utilise the services of a neighbouring jurisdiction. Spillover grants may help to compensate jurisdictions that are adversely affected.
} 
There is a need for a model that takes into account not only the assignment of expenditure functions to one or another level, but also provides principles to decide when and to what extent responsibilities should be shared. The theory of fiscal federalism provides little or no guidance to determine where centralised regulation with decentralised implementation may be advisable (Oates 1994: 143-147). However, the theoretical framework for expenditure assignment hinges on the distinction between national public goods on the one hand, and regional and local public goods with geographically more limited benefit areas on the other. Ahmad et al (1997: 25-26) concede:

\begin{abstract}
"Most goods that governments supply, however, do not fit neatly into either one of these two categories. For these mixed goods some degree of decentralization coupled with some centralized coordination of policy is both feasible and desirable, owing to unclear benefit regions, externalities, or national redistributional implications... When conflicting goals arise, the analysis of which level should be assigned expenditure responsibility can become quite complicated and subject to normative bias."
\end{abstract}

\title{
2.2.1.3 Framework for Expenditure Assignment
}

Oates (1993: 3-30) describes the benefits of federal government as enabling a compromise between the economic case for centralised government on the one hand, and the economic case for decentralised government on the other. Shah (1994a: Table 1.1 and 1994b: Table 2) proposes a conceptual framework for the assignment of expenditure functions that expresses this compromise. The benefits and costs of a number of functions are national in scope (e.g. defence and foreign affairs) ${ }^{29}$ Due to their primarily local benefits, basic services (e.g. water, sewerage and refuse) are assigned to local government. However, the framework does not resolve the above-mentioned problem with mixed goods. This is partially due to the complexity of some sectors. For instance, while there are advantages to the local provision of primary education and preventative health care, such as allowing communities to express cultural and curative preferences, economies of scale and externalities imply that more centralised control of tertiary education and hos-

This would require that the extent that mon-residents use a certain service, as well as their origin, be known to the providing authority.

29 For example, frontier regions may be more concerned with national defence issues, while interior communities might simply depend on the border regions to protect them. Therefore, if defence was a subnational function, this assignment would lead to the under-supply of a national good (Ahmed et al 1997: 29). 
pitals may be warranted (Ahmad et al 1997: 25). Other factors may further influence expenditure assignment. Commenting on the "dangers of decentralisation", Prud'homme (1995: 215) notes that subnational capacity needs to be considered to determine the extent to which responsibilities are to be decentralised: "For decentralized units to be efficient and achieve the potential benefits of decentralization, they must be sufficiently large in terms of population, activities, and income. This efficiency can be increased by personal training and institution building, but decentralizing taxes and even expenditures to small and weak local governments is unlikely to be successful." The comparative data below show the distribution of governmental expenditure in selected countries, which is a summary indicator of expenditure decentralisation. The variations indicate that there is no single model that is empirically dominant, and that careful consideration needs to be given as to why certain variations occur in individual countries. 
Table 1: Theoretical Framework for Expenditure Assignment

\begin{tabular}{lccc}
\hline Expenditure category & Regulation & Administration & Comments \\
\hline Defence & $\mathrm{N}$ & $\mathrm{N}$ & Benefits and costs national in scope. \\
Foreign affairs & $\mathrm{N}$ & $\mathrm{N}$ & Benefits and costs national in scope. \\
Intemational trade & $\mathrm{N}$ & $\mathrm{N}$ & Benefits and costs national in scope. \\
Currency and banking & $\mathrm{N}$ & $\mathrm{N}$ & Benefits and costs national in scope. \\
Immigration & $\mathrm{N}$ & $\mathrm{N}$ & Benefits and costs national in scope. \\
Unemployment insurance & $\mathrm{N}$ & $\mathrm{N}$ & Benefits and costs national in scope. \\
Airlines and railways & $\mathrm{N}$ & $\mathrm{N}$ & Benefits and costs national in scope. \\
Natural resources & $\mathrm{N}$ & $\mathrm{N}, \mathrm{R}, \mathrm{L}$ & Promotes a common market. \\
Environment & $\mathrm{N}, \mathrm{R}, \mathrm{L}$ & $\mathrm{R}, \mathrm{L}$ & Benefits and costs may vary in scope. \\
Industry and agriculture & $\mathrm{N}, \mathrm{R}, \mathrm{L}$ & $\mathrm{R}, \mathrm{L}$ & Significant interjurisdictional spillovers. \\
Education & $\mathrm{N}, \mathrm{R}, \mathrm{L}$ & $\mathrm{R}, \mathrm{L}$ & Varying benefit regions. \\
Health & $\mathrm{N}, \mathrm{R}, \mathrm{L}$ & $\mathrm{R}, \mathrm{L}$ & Varying benefit regions. \\
Social welfare & $\mathrm{N}, \mathrm{R}, \mathrm{L}$ & $\mathrm{R}, \mathrm{L}$ & Unclear benefit regions. \\
Highways and roads & $\mathrm{N}, \mathrm{R}, \mathrm{L}$ & $\mathrm{R}, \mathrm{L}$ & Some roads with significant spillovers. \\
Police & $\mathrm{R}, \mathrm{L}$ & $\mathrm{R}, \mathrm{L}$ & Primarily local benefits. \\
Fire protection & $\mathrm{L}$ & $\mathrm{L}$ & Primarily local benefits. \\
Water, sewerage, refuse & $\mathrm{L}$ & $\mathrm{L}$ & Primarily local benefits. \\
\hline Soure Adapt &
\end{tabular}

Source. Adapted from Shah (1994a: Table 1.1 and 1994b: Table 2).

Notes. $\mathrm{N}=$ national govemment, $\mathrm{R}=$ regional govemment, $\mathrm{L}=$ local government.

Table 2: Distribution of Government Expenditure in Selected Countries

\begin{tabular}{cccccc} 
& \multicolumn{4}{c}{ Total general government expenditure* } \\
\hline & & \multicolumn{3}{c}{ As \% of total } \\
\hline Country & Year & As \% of & Central gov- & Regional gov- & Local govern- \\
& GDP & ernment & emment & ment \\
\hline
\end{tabular}

Industrial countries

$\begin{array}{lccccc}\text { Australia } & 1995 & 46.5 & 59.0 & 36.0 & 5.0 \\ \text { Belgium } & 1994 & 56.5 & 88.5 & \text { n.a. } & 11.5 \\ \text { Canada } & 1993 & 60.1 & 41.7 & 41.2 & 17.1 \\ \text { France } & 1995 & 56.5 & 82.3 & \text { n.a. } & 17.7 \\ \text { Germany } & 1995 & 57.2 & 59.2 & 24.1 & 16.7 \\ \text { Netherlands } & 1995 & 66.5 & 76.4 & \text { n.a. } & 23.6 \\ \text { Norway } & 1994 & 60.2 & 68.4 & \text { n.a. } & 31.6 \\ \text { Spain } & 1993 & 55.9 & 70.4 & 18.2 & 11.3 \\ \text { United Kingdom } & 1995 & 54.1 & 77.3 & \text { n.a. } & 22.7 \\ \text { United States } & 1994 & 41.3 & 53.4 & 25.6 & 21.0\end{array}$

Developing and transition countries

\begin{tabular}{llllll} 
Argentina & 1992 & 21.8 & 55.1 & 44.9 & u. \\
Brazil & 1993 & 56.6 & 65.7 & 24.8 & 9.5 \\
India & 1993 & 30.8 & 54.7 & 45.3 & u. \\
Kenya & 1994 & 30.0 & 96.1 & n.a. & 3.9 \\
Mexico & 1993 & 19.1 & 78.3 & 21.7 & u. \\
Poland & 1995 & 51.8 & 83.8 & n.a. & 16.2 \\
Russian Federation & 1995 & 38.5 & 62.4 & u. & 37.6 \\
South Africa & 1994 & 50.1 & 66.3 & 25.4 & 8.3 \\
Thailand & 1995 & 17.3 & 92.6 & n.a. & 7.4 \\
\hline
\end{tabular}

Source. Intemational Monetary Fund (1997).

Notes. n.a. stands for not applicable, u. stands for data unavailable.

* General govemment is defined to include the central govemment; the social security system; and regional and local governments. Expenditure covers all non-repayable payments (whether capital or current, requited or not) by government. 


\subsubsection{Revenue Assignment}

The expenditure requirements of the different levels of government should inform the assignment of revenue sources to ensure that each level has sufficient revenues to fulfil its respective functions (Wiltshire 1989: 181).$^{30}$ The following principles indicate which sources of revenue are suitable for subnational governments (e.g. Norregaard 1997, Spahn 1995, Shah 1994a: 13 and 1994b: 18-21). The argument is usually presented in reverse order compared with expenditure assignment, where the assumption tends to be in favour of decentralisation.

\subsubsection{Revenue Centralisation}

Progressive taxes with redistribution objectives ${ }^{31}$ should be centralised, because a decentralised redistribution policy may easily become self-defeating. For example, if a local jurisdiction decided to redistribute income to poor residents, rich residents may simply move on to other jurisdictions where this is not the case. The authority attempting redistribution would be left with a population that is on average less wealthy, which in turn would leave fewer resources for the purpose of redistribution.

Taxes suitable for macro-economic management or stabilisation, such as company taxes, should be centralised to avoid distortions within the country. In addition, the usefulness of these taxes to influence the direction of the overall economy is likely to be weakened or even lost when different jurisdictions impose differential rates.

Taxes that have widely differential tax bases between jurisdictions, for instance those linked to natural resource exploitation, should be centralised to avoid extreme inequalities. As natural resources tend to be subject to price volatility, they also constitute an unreliable source of revenue for subnational authorities.

${ }^{30}$ The decentralisation of expenditure functions should be accompanied by an equivalent decentralisation of resources, and vice versa. In practice, two types of mismatches have been noted (Shah 1994b: 43): (1) Federal deficits have been passed on to subnational governments by expenditure decentralisation without a concomitant increase in revenue for subnational governments. This is referred to as "unfunded mandates". A good country example for this problem is the Russian Federation (Craig et al 1997). (2) The opposite happened in Brazil as a result of the implementation of the Constitution of the Federal Republic of Brazil (1988), which devolved revenues without a concomitant transfer of functions. This constrained the federal govemment and provided perverse incentives for fiscal management at subnational level (Pablos 1997, TerMinassian 1997b, Oliveira and Velloso 1994, Campbell 1991: 28-30). 
Taxes on mobile factors, such as income, should remain with the central government. A high local tax rate on corporate profit, for example, may lead a business to move to a jurisdiction with a lower rate. In addition, competition between jurisdictions may erode the tax base. The more mobile a tax base, the greater the case for centralisation.

Taxes with economies of scale in tax administration should be administered by the national government. For example, if a value-added tax (VAT) were to be levied by the subnational jurisdiction in which consumption takes place ${ }^{32}$, implementation would require border controls between different jurisdictions. Such a system would not only be costly to administer, but may also impede the free movement of goods and services.

\subsubsection{Revenue Decentralisation}

Taxes on completely immobile factors, such as property and land, are most suited for the local level. Since the tax base cannot move in a physical sense, differences in tax rates between jurisdictions are unlikely to cause serious problems. With taxes on immobile factors it is also always clear which authority is entitled to the revenue they yield.

Single-stage sales taxes ${ }^{33}$ are suitable to be levied by subnational governments, provided that they do not levy these taxes with highly different rates. Otherwise, residents will be encouraged to shop in other jurisdictions. The extent to which this is likely to occur depends on factors such as the vicinity of jurisdictions with differential rates, the cost of travel, and the value of the goods purchased.

User charges and license fees can be used by all levels of government. They are especially suitable for local governments to the extent that costs and benefits are "internalised" to the local taxpayer.

\footnotetext{
${ }^{31}$ Progressive taxation is associated with an income tax system which levies a proportionately higher tax rate on those with higher incomes.

32 The destination principle implies that the tax is levied by the jurisdiction in which consumption takes place, independent of the origin of the goods. The ongin principle requires the tax to be levied by the jurisdiction in which production takes place. Norregaard (1997: 65) notes that the need to make the VAT neutral with regard to the spatial allocation of production and consumption implies that it should generally conform with the destination principle.

${ }^{33} \mathrm{~A}$ distinction is made between single-stage sales taxes (e.g. excises and retail taxes) and multi-stage sales taxes (e.g. tumover taxes and VATs). Excises are taxes on specific goods (e.g. tobacco and alcohol) or services manufactured, sold or consumed in a jurisdiction.
} 


\subsubsection{Framework for Revenue Assignment}

Based on the arguments outlined above, Shah (1994a: Table 1.4 and 1994b: Table 6) proposes a conceptual basis for tax assignment. It is clear that economic theory favours the centralisation of the main sources of revenue used by modern governments (e.g. income taxes and VAT). Spahn (1995: 221) further observes: "Although guidelines to local taxation can be found in the theory of federalism, their impact on actual arrangements is remarkably weak." The comparative data below show the distribution of tax revenue in selected countries, indicating various degrees of revenue decentralisation. A range of factors may influence these revenue patterns. For instance, local revenue bases tend to be more substantial in developed countries. The existence of a regional tier of government, which may claim certain tax bases, also impacts on tax assignment. Nonetheless, in most cases the revenue shares of subnational governments are smaller than their expenditure needs require. This is sometimes addressed through tax-sharing, where the central government shares the revenue from a particular tax, or through general revenue-sharing. Alternatively, subnational governments are dependent on income from intergovernmental transfers and grants, which are discussed in detail in the following section. 
Table 3: Theoretical Framework for Revenue Assignment

\begin{tabular}{lcccc}
\cline { 2 - 4 } Revenue source & \multicolumn{2}{c}{ Determination of } & & Comments \\
\hline Customs & Rate & Collection and & administration \\
Corporate income & $\mathrm{N}$ & $\mathrm{N}$ & $\mathrm{N}$ & $\begin{array}{c}\text { International trade. } \\
\text { Natural resources }\end{array}$ \\
VAT & $\mathrm{N}$ & $\mathrm{N}$ & $\mathrm{N}$ & Mobile factor, stabilisation tool. \\
Personal income & $\mathrm{N}$ & $\mathrm{N}$ & $\mathrm{N}$ & Unequally distributed tax bases. \\
Retail sales & $\mathrm{R}$ & $\mathrm{R}, \mathrm{L}$ & $\mathrm{N}$ & Economies of scale in administration. \\
or & $\mathrm{N}$ & $\mathrm{R}$ & $\mathrm{N}$ & Redistributive, mobile factor. \\
Property, land & $\mathrm{R}$ & $\mathrm{L}$ & $\mathrm{L}$ & Higher compliance cost. \\
Fees, user charges & $\mathrm{N}, \mathrm{R}, \mathrm{L}$ & $\mathrm{N}, \mathrm{R}, \mathrm{L}$ & $\mathrm{N}, \mathrm{R}, \mathrm{L}$ & Lower compliance cost. \\
Excises & $\mathrm{R}, \mathrm{L}$ & $\mathrm{R}, \mathrm{L}$ & $\mathrm{R}, \mathrm{L}$ & Relatively immobile factors, residence-based. \\
\hline Source
\end{tabular}

Source. Adapted from Shah (1994a: Table 1.4 and 1994b: Table G).

Notes. $\mathrm{N}=$ national government, $\mathrm{R}=$ regional government, $\mathrm{L}=$ local govemment.

Table 4: Distribution of Tax Revenue in Selected Countries

\begin{tabular}{|c|c|c|c|c|c|}
\hline \multirow[b]{3}{*}{ Country } & \multirow[b]{3}{*}{ Year } & \multicolumn{4}{|c|}{ Total general government tax revenue* } \\
\hline & & & \multicolumn{3}{|c|}{ As $\%$ of total } \\
\hline & & $\begin{array}{c}\text { As } \% \text { of } \\
\text { GDP }\end{array}$ & $\begin{array}{c}\text { Central gov- } \\
\text { emment }\end{array}$ & $\begin{array}{c}\text { Regional gov- } \\
\text { ernment }\end{array}$ & $\begin{array}{c}\text { Local govern- } \\
\text { ment }\end{array}$ \\
\hline Industrial countries & & $\sigma$ & & & \\
\hline Australia & 1995 & 28.9 & 76.6 & 19.9 & 3.5 \\
\hline Belgium & 1994 & 45.7 & 94.8 & n.a. & 5.2 \\
\hline Canada & 1993 & 38.7 & 53.5 & 36.5 & 10.0 \\
\hline France & 1995 & 42.4 & 89.8 & n.a. & 10.2 \\
\hline Germany & 1995 & 41.1 & 73.0 & 21.0 & 6.0 \\
\hline Netherlands & 1995 & 44.7 & 96.3 & n.a. & 3.7 \\
\hline Norway & 1994 & 40.3 & 78.6 & n.a. & 21.4 \\
\hline Spain & 1993 & 33.2 & 86.6 & 4.6 & 8.8 \\
\hline United Kingdom & 1995 & 34.8 & 96.4 & n.a. & 3.6 \\
\hline United States & 1994 & 27.0 & 65.7 & 20.6 & 13.7 \\
\hline \multicolumn{6}{|c|}{ Developing and transition countries } \\
\hline Argentina & 1992 & 19.8 & 57.2 & 42.8 & u. \\
\hline Brazil & 1993 & 25.7 & 71.4 & 26.0 & 2.6 \\
\hline India & 1993 & 14.9 & 61.8 & 38.2 & $\mathbf{u}$. \\
\hline Kenya & 1994 & 21.1 & 97.8 & n.a. & 2.2 \\
\hline Mexico & 1993 & $\because \quad 16.3$ & 84.6 & 15.4 & u. \\
\hline Poland & 1995 & 40.0 & 92.1 & n.a. & 7.9 \\
\hline Russian Federation & 1995 & 29.0 & 60.0 & $\mathbf{u}$. & 40.0 \\
\hline South Africa & 1994 & 27.6 & 91.4 & 3.1 & 5.5 \\
\hline Thailand & 1995 & 18.2 & 94.9 & n.a. & 5.1 \\
\hline
\end{tabular}

Source. International Monetary Fund (1997).

Notes. n.a. stands for not applicable, u. stands for data unavailable.

* General govemment is defined to include the central govemment; the social security system; and regional and local governments. Tax revenue is defined as unrequited, compulsory payments to govemment, excluding non-tax categories (e.g. fees, sales and fines). 


\subsubsection{Intergovernmental Transfers and Grants}

\subsubsection{The Need for Transfers and Grants}

Imbalances or "fiscal gaps" occur when expenditure needs are not covered by available revenue. There are two types of such fiscal imbalances: ${ }^{34}$ Horizontal imbalances arise when resources, in relation to expenditure functions, are unevenly spread between jurisdictions within the same level of government. Vertical Imbalances are due to a mismatch between the assignment of expenditure functions and revenue sources to different levels of government, in which case one level may find that its expenditure needs are not covered by the revenue at its disposal. To ensure that governments are able to fulfil the functions assigned to them, there is a need to address horizontal and vertical imbalances.

Vertical imbalances can be addressed by sharing the yield of a particular tax, or a general pool of revenues, between different levels of government. An entitlement to receive a percentage of the proceeds of a shared tax can make the income derived from constitutionally shared taxes very close to own revenue ${ }^{35}$ (Biehl 1994: 88). The greater the fiscal gap, after the sharing of revenue if this is practised, the more important are intergovern mental transfers and grants (Ahmad and Craig 1997, Shah 1994a: 22-51 and 1994b: 2439, Oates 1993: 65-118). Apart from ensuring that governments have sufficient revenue to fulfil their functions, there are various other objectives of transfers and grants.

\subsubsection{Objectives of 'Transfers and Grants}

Stabilisation can be achieved through adjusting the total level of transfers, as well as their distribution. This may be the case when some regions are more heavily affected than others by economic downturns. A decline in demand for natural resources, for instance, directly affects those regions were mining operations provide a substantial share of employment opportunities. Shah (1994a: 32) outlines the counter-cyclical effect that can be achieved: "Grants could increase in periods of slack economic activity to encourage local expenditure and diminish during the upswing of the economic cycle."

34 The indicator of "fiscal dependency" is used to measure such imbalances (e.g. Rao and Vaillancourt 1994: 104, Wolman 1990: 40, Nathan and Balmaceda 1990: 62). The share of regional or local expenditure that is not covered by own revenue indicates the extent of fiscal dependency of subnational governments. 
Equity between the various regions of a country often requires that those authorities with insufficient fiscal capacities receive additional funds to provide a basic level of services to the public (Heyns 1995, Ladd and Yinger 1994). While some countries accept differential benefits, others emphasise the need to provide equivalent services. Equalisation may be aimed at equalising the actual performances (outputs) of different jurisdictions in order to achieve uniformity. Alternatively, the goal may be to equalise fiscal capacities (inputs) without influencing the specific configuration of services (Wehner 1997a: 4).

Minimum or national standards aim at ensuring a minimum of service delivery to be achieved by subnational units. Such standards are often thought to be in the national interest, to insure social and economic unity, or to further social justice. This objective is closely linked to the concept of output equity. ${ }^{36}$

Efficiency in the provision of a service is threatened by spillovers: "In such circumstances, regional governments may consider only benefits to their own citizens and underprovide public services, hence yielding a case for supplementary central government grants for the given purpose" (Ahmad and Craig 1997: 82).

Sometimes these objectives are in conflict with each other (Ahmad and Craig 1997: 8486). For instance, stabilisation and equity goals may be in conflict when the activities of the national government have a differential effect on subnational authorities. The objectives of equity and efficiency may be in conflict where the extent of equalisation rewards regions with a low fiscal capacity.

\subsubsection{The Design of Transfers and Grants}

The question remains as to which design of transfers and grants can be applied for achieving such objectives. Several basic choices have to be made by the policy-maker.

Conditionality versus Non-Conditionality. The contributing government can increase its control over the spending activities of the recipient government by attaching conditions to any payments that are made. This may be necessary to ensure that certain minimum

${ }^{35}$ Own revenue is the revenue derived from taxation that is levied directly by a jurisdiction. 
standards are met or that a specific expenditure is effected: "The main justification for conditional grants over unconditional grants, however, must be that local decision making fails to produce the socially optimal outcome, as in the case of interjurisdictional spillovers..." (Ahmad and Craig 1997: 87). The specific design of conditionality also needs to be considered (Wehner 1997a: 4). Input-based conditions restrict the use of a grant to a specific sector or programme. Output-based conditions, on the other hand, requires certain targets to be achieved by the recipient. In the latter case, there is a strong incentive to provide a service at the least possible cost, as the recipient authority would be free to use the remainder of a grant on its own priorities. Problems arise where there is a lack of capacity to enforce conditions.

Matching versus Non-Matcbing Conditional Grants. A Matching requirement forces the recipient government to supplement a granted amount for a specific purpose with own funds equivalent to an agreed percentage of the grant. The national government is thereby able to influence the spending of the recipient government by providing an incentive to prioritise certain services. Problems may arise when some regions are able to exercise more influence on the total size of a matching grant, simply due to their fiscal capacity.

The Extent of Equalisation. The more weight is assigned to indicators of fiscal need, the greater the equalising effect of such transfers or grants across regions.

Open-Ended versus Capped.37 Open-ended matching grants can serve to fully acknowledge detectable spillovers, thereby ensuring that the desired level of services is provided. However, it is often necessary to cap the total amount available for such purposes due to budgetary constraints. Without caps, national spending may be determined in part by subnational decisions, which woúld blur accountability.

Grant design should take into account the objectives that are to be achieved, as different scenarios require different designs (Shah 1994b: 24-27). For example:

${ }^{36}$ In some countries, such as Canada, the term "national" standards is often used instead of "minimum" standards, to denote the idea that some common level of services, wherever one lives, is an aspect of national citizenship.

${ }^{37}$ An open-ended payment is not subject to a maximum total amount. To the contrary, if a payment is capped, a limit is set with regard to the total amount. 
Vertical fiscal imbalances, due to expenditure needs being greater than revenue-raising capacity, may be addressed through general transfers (or revenue-sharing). Should this not suffice, changes to the assignment of functions and revenue sources may be necessary.

Horizontal fiscal imbalances, due to different revenue-raising capacities, may call for general equalisation transfers. These would protect the general ability of recipient governments to fulfil their functions, while not distorting their expenditure decisions.

Benefit spillovers may be fully compensated through open-ended matching transfers, with the matching rate determined by the benefit-spillout ratio (i.e. the cost incurred by the use of a particular service by non-residents).

Ensuring minimum or national standards may be effected by conditional grants. The recipient would be bound to fulfil the requirements the grantor attaches to such funds, with the result that national priorities are reflected in subnational expenditures.

In practice, numerous problems are encountered. These include confusion about transfer and grant objectives, and the appropriate design to achieve such an objective, a lack of transparency with regard to allocations, or the absence of explicit standards. ${ }^{38}$ In other instances, especially in developing countries, a lack of reliable data is an obstacle to the design of an appropriate formula. ${ }^{39}$

\subsubsection{Institutional Arrangements}

There are at least four possible models for assigning institutional responsibility for the guidance of a system of transfers and grants. First, the task could be delegated to an independent panel of experts. This would place emphasis on depoliticising the process, but the use of non-elected specialists raises questions of accountability. The Australian Commonwealth Grants Commission (Craig 1997: 184-185) and the Indian Finance Commissions (Hemming et al 1997: 531-532) are examples of this option. Second, the

\footnotetext{
38 These problems have been well documented in the Indian case (Hemming et al 1997: 531-533, Cashin and Sahay 1995, Chelliah 1994). Increasingly larger amounts of the Union Budget have been earmarked for the states over the past two decades (Economic Times, 27 January 1999). The Tenth Finance Commission proposed to guarantee the states a definite share in the total central pool of taxes to ensure greater predictability, stability and transparency (Andhra Pradesh Doily News, 1 March 1997).

39 The case of Ethiopia is instructive in this regard (Brosio and Gupta 1997).
} 
central government could be responsible for determining subnational shares. This would allow greater control by the centre, but undermines the autonomy of subnational governments. For instance, federal grants in the United States, in relation to state and local expenditures, have fluctuated substantially over the past decades (Stotsky and Sunley 1997: 368-372). Third, the process could be finalised by agreement in an intergovernmental body, based on bargaining. This may help to build consensus amongst the participants, but may also favour a few participants with strong bargaining positions. This has been a characteristic feature in Canada (Krelove et al 1997: 213-220). Finally, a system of transfers and grants may be outlined in detail in a constitution, which greatly reduces the need to assign responsibility for the design of transfers and grants according to one of the above options. Such arrangements produce predictability, but reduce the flexibility to adapt a system in line with changing needs and circumstances. For instance, the Basic Law for the Federal Republic of Germany (1949) outlines the revenue shares from particular taxes accruing to the different levels of government, and the way in which these are to be distributed (Spahn and Föttinger 1997: 228-230).

\subsubsection{Framework for Transfers and Grants}

A specific design of intergovernmental transfers and grants should attempt to reconcile a number of criteria (Shah 1994a: 33-34): subnational autonomy, revenue adequacy, equity, predictability, efficiency, simplicity, incentive for sound fiscal management, and safeguarding the grantor's objectives. Clearly, these criteria can be in conflict with each other. For example, there is a trade-off between protecting the autonomy of subnational governments and the desire to safeguard the grantor's objectives. In practice, value judgements determine which of these principles will be maximised. 
Figure 1: Regional Fiscal Dependency in Selected Countries

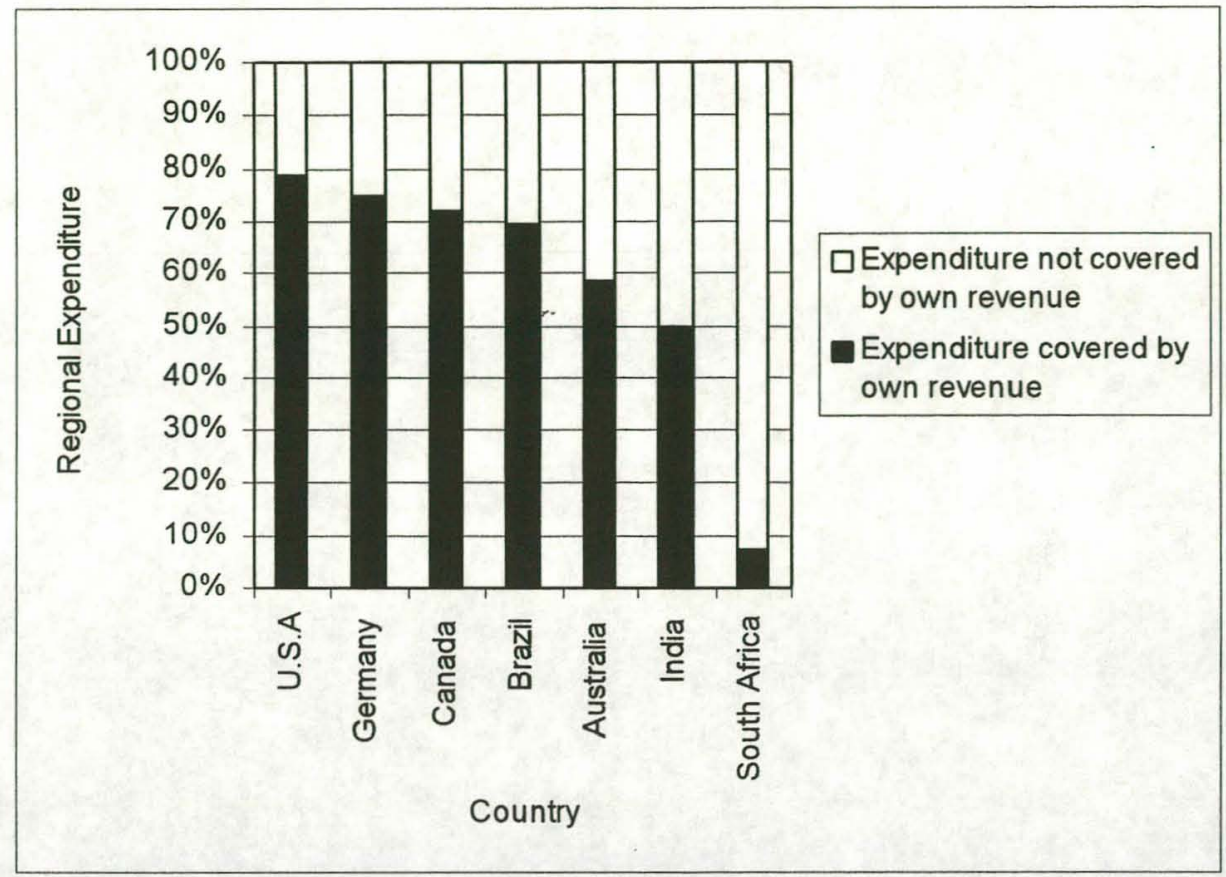

Source. Wehner (1997a).

Notes. The ratio of total regional revenue (excluding grants) in total regional expenditure is for the fiscal years beginning in 1993 (Brazil and India), 1994 (Canada and the United States) and 1995 (Australia, Germany and South Africa). Based on data from the International Monetary Fund (1997).

\section{Table 5: Theoretical Framework for Intergovernmental Transfers and Grants}

\begin{tabular}{|c|c|}
\hline Criteria & Comments \\
\hline Autonomy & $\begin{array}{l}\text { Subnational governments should have independence and flexibility in setting their } \\
\text { own priorities. }\end{array}$ \\
\hline Revenue Adequacy & $\begin{array}{l}\text { Subnational governments should have adequate revenues to fulfil the functions } \\
\text { assigned to them. }\end{array}$ \\
\hline Equity & $\begin{array}{l}\text { Allocations to subnational governments should vary positively with fiscal need } \\
\text { factors and inversely with taxable capacity. }\end{array}$ \\
\hline Predictability & $\begin{array}{l}\text { Transfer and grant mechanisms should ensure the predictability of subnational gov- } \\
\text { ernment shares. }\end{array}$ \\
\hline Efficiency & $\begin{array}{l}\text { Design of system should be neutral as to subnational government choices about the } \\
\text { allocation of resources to different sectors or types of activity. }\end{array}$ \\
\hline Simplicity & $\begin{array}{l}\text { Allocations should be based on objective factors which are transparent and not } \\
\text { prone to manipulation. }\end{array}$ \\
\hline Incentive & $\begin{array}{l}\text { Design of system should provide incentives for sound fiscal management and dis- } \\
\text { courage inefficient practices. }\end{array}$ \\
\hline $\begin{array}{l}\text { Safeguard of grantor's } \\
\text { objectives }\end{array}$ & $\begin{array}{l}\text { Design of grants should ensure that the grant recipients properly adhere to certain } \\
\text { well-defined objectives. }\end{array}$ \\
\hline
\end{tabular}




\subsubsection{Borrowing Arrangements}

\subsubsection{The Need for Subnational Government Borrowing}

The income of a government is in many cases insufficient to finance all its spending, which results in a deficit. ${ }^{40}$ Although a government may decide to raise taxes to cover the deficit, it may also resort to borrowing.

Subnational government borrowing is required to finance substantial capital ${ }^{41}$ spending (Oates 1993: 153). Equity considerations support the argument that the cost of an investment project should be spread across a number of years to coincide more closely with the stream of future benefits. However, if the returns from an investment do not cover the costs of debt repayment, future generations are likely to have to pay higher taxes to pay off debt that was accumulated in the past. High costs of debt repayment, in turn, restrict the ability of the government to fund needed programmes (Abedian et al 1997: 25-29). In addition, it might also be argued that access to borrowing fosters efficiency. Financial markets would penalise poor performance by raising interest rates or blocking access to further funds.

\subsubsection{Possible Approaches to Subnational Government Borrowing}

The following are the main possible approaches to subnational borrowing (TerMinassian and Craig 1997):

Total reliance on market discipline forfeits any legal constraints on the borrowing activities of subnational governments (e.g. Canada, Finland and Russia).

A co-operative approach to debt controls arrives at limits on the indebtedness of subnational governments through a negotiating process between the central and lower levels of government (e.g. Australia and Denmark).

\footnotetext{
${ }^{40} \mathrm{~A}$ deficit is the amount of money by which planned govemment expenditures are more than the revenue expected to be available.

${ }^{41}$ Capital goods are goods that are used in the production of other goods or services, for instance machinery, vehicles, buildings etc.
} 
A rules-based appraach controls subnational borrowing through standing legal rules (e.g. Germany, Switzerland and the United States). For instance, borrowing may be restricted to investment purposes (the so-called "golden rule"), or required not to exceed a certain level of indebtedness.

Direct centralised control over subnational borrowing (e.g. Chile and Spain) may take a number of forms. The central government may set annual limits on the overall debt of individual subnational jurisdictions, authorise individual borrowing activities, or undertake all government borrowing with subsequent on-lending to subnational authorities.

Ter-Minassian and Craig (1997: 169-171) conclude that no standard pattern can be observed with regard to the regulation of subnational government borrowing. They note that the nature and coverage of controls on subnational government borrowing reflects the individual country's history, the balance of power between various levels of government, macro-economic conditions and the development of financial markets.

\subsection{Chapter Conclusion}

This chapter reviewed considerations in the design of intergovernmental fiscal relations. The discussion generated economic reference frameworks with regard to the assignment of expenditure responsibilities, sources of revenue, and the design of a system of intergovernmental transfers and grants. These frameworks can be utilised for the assessment of the South African system. However, the analysis also indicated that constitutions can impose limits on fiscal design. The implication is that any policy recommendations concerning fiscal design cannot ignore an existing constitutional framework. This notion will be developed further in the following chapter. 


\section{CHAPTER 3:}

\section{FISCAL FEDERALISM IN COMPARATIVE PERSPECTIVE}

This chapter contains a comparison of two countries which served as prominent reference models for the structure of government during the constitutional negotiations in South Africa. The chapter tracks some of the key options that constitutional designers were faced with, and which have a bearing on fiscal arrangements. The purposes of the chapter are to demonstrate the practical relevance of the theoretical considerations outlined in the previous chapter, and to provide a comparative context, from a fiscal perspective, for the description and analysis of the South African system.

During the constitutional negotiations in South Africa, Canada and Germany were repeatedly used as reference models for the design of the country's provincial system (e.g. Constitutional Assembly 1995, De Villiers 1994b). ${ }^{42}$ Canada and Germany exemplify diametrically opposed visions of a system of regional government: the divided and the shared model respectively. Canada is perhaps the most decentralised federation in the world, whereas the German system is characterised by a strong central government. While the Canadian model appealed to supporters of substantial autonomy for the regions, the German "unitary federation" (Hesse 1962) served as a model for those favouring a system of regional government that complements the role of the centre. ${ }^{43}$

Canada is a federation of ten provinces and three territories characterised by differences in territorial size, economic development, population and ethnic composition. The British North America Act of 1867 and its subsequent amendments laid the basis for today's federalism (Simeon and Robinson 1990: 19-30). ${ }^{44}$

\footnotetext{
42 Simeon (1998: 50-51) summarises: "Among the models which South Africa considered were those of Canada and Germany - Canada perhaps because of the Commonwealth link, and its marriage of federalism with a parliamentary system of government, Germany perhaps because of other cultural affinities, and its quite different model: The United States, India and Australia have also been sources of ideas, in the latter two cases in large part because they are relatively centralised models."

43 The German system appealed to a group of ANC strategists who visited the country as part of a study tour in 1992. Its integrated design is favoured in the 1993 "ANC Regional Policy" (Besdziek 1998). 44 The Constitution Act (1982) attempted to modernise the Constitution. It added a Charter of Rights, the recognition of Aboriginal rights, a commitment to the principle of equalisation and an amending formula, among other things. The British Nortb America Act (1867) was renamed the Constitution Aat (1867).
} 
Germany is a federation of 16 provinces (Länder), five of which were incorporated from the territory of the former German Democratic Republic with unification on 3 October 1990 (Burgess and Gress 1993). The Basic Law for the Federal Republic of Germany (Grundgesetz) of 1949 regulates the relationship between the levels of government. ${ }^{45}$

\subsection{Expenditure Assignment}

A key issue in the assignment of expenditure functions is to what extent functions should be shared or divided. Shared functions usually involve one level setting norms and standards, while delegating implementation to lower levels of government. The clear division of functions, on the other hand, relies on the furthest possible separation of responsibilities. If one level is responsible for setting norms and standards that are administered by another level, the question follows whether and how the latter can participate in the formulation of policy.

\subsubsection{Canada}

The Constitution Act (sections 91 and 92) lists exclusive federal and provincial functions. ${ }^{46}$ The federal government regulates the provision of goods and services with national scope, such as defence and international affairs. The provinces are assigned the right to regulate "generally all matters of a merely local or private nature in the province", which includes health care and education. Local governments in Canada are creatures of their provincial government (Bird and Chen 1998) ${ }^{47}$ Formal concurrency is limited to agriculture and immigration. In the case of conflict in the areas of concurrent federal and provincial powers, federal law supersedes. ${ }^{48}$ Apart from these cases, the Canadian Con-

\footnotetext{
45 For overviews of Germany's fiscal Constitution, refer to Laufer and Münch (1997: 150-185) and Bundesministerium der Finanzen (1998 and 1996: 93-108).

46 The Canadian Supreme Court plays a pivotal role in determining into whose area of competence a particular piece of legislation falls (Cotler 1296). For an analysis of the impact of Supreme Court on federalism in the United States, see Wise (1998).

47 There are approximately 8000 local units, including agencies, commissions, special-purpose boards, municipal governments and school authorities.

48 In 1949 old age pensions was added as an area of concurrent jurisdiction in which provinces retain paramountcy (Simeon 1998: 51).
} 
stitution emphasises exclusive functional responsibility. ${ }^{49}$ There is no unified public service, and the levels of government rely on separate administrations to implement policies.

The role of the Senate as a representative of the provinces in the national law-making process is largely symbolic (Verney 1995: 95). Despite formal powers, the regional chamber rarely refuses the passage of a bill. Since it is an appointed body ${ }^{50}$, the Senate is not considered to have the political mandate to obstruct the democratically elected House of Commons. The failure of the Senate as an effective provincial representative has strengthened the role of "federal-provincial diplomacy" (Simeon 1972) through negotiations by the executives of the different governments (Watts 1990: 3).

\subsubsection{Germany}

The Grundgesetz assigns specific legislative competencies to the federal government (Bund) (Art. 71 and 73), such as defence, foreign affairs, immigration and currency matters. The residual competencies are left to the Länder (Art. 70), including education, police and internal administration (Führ 1997: 28-58, Hesse and Ellwein 1992: 78-81). A substantial list of concurrent competencies (Art. 72, 74 and 74a) names those areas in which the Länder may exercise legislative authority as long as the Bund does not do so (e.g. welfare and public health). The Bund also has a framework legislation authority that allows it to legislate basic norms and standards, but no details, in seven areas (Art. 75) (e.g. the public service, tertiary education, and the media). Furthermore, article 91a provides for a number of shared responsibilities (e.g. the construction of universities and coastal protection). In case of conflict between legislation, federal law supersedes if the federal government has jurisdiction (Art. 31). Federal norms and standards are encouraged by the constitutional demand for the creation of equal living conditions throughout the country (Art. 72(2)). The functions of local governments are mostly delegated, relating to public health and basic services (water, electricity, gas, public transport and fire protection) ${ }^{51}$ Charac-

\footnotetext{
${ }^{49}$ Some exclusively assigned areas have been subject to increased co-operation between the levels of govemment. For example, innovative health care programmes were pioneered in the western provinces, but later promoted jointly by the federal and provincial levels (Gray and White 1989). De facto concurrency also occurs when both levels move into new areas of activity that are not assigned in the Constitution, as they were not matters of concem in the previous century when it was drafted (Simeon 1998: 52).

${ }^{50}$ It consists of 24 senators for each of the four divisions of Ontario, Quebec, the three maritime provinces and the four westem provinces. The senators are appointed by the federal government, and once appointed hold office until age 75. Party alignment plays the major role in the appointment process. ${ }^{51}$ Germany has a two-tier system of local govemment (De Villiers 1997a: 6, Hesse and Ellwein 1992: 6870).
} 
teristic of German federalism is the integration of Bund and Länder tasks. While the Bund has broad legislative authority to set uniform standards, the Länder provide most of the administrative infrastructure. The Bund has few executive organs (e.g. the foreign service, army and border control). Scharpfs (1988) concept of "policy interlacing" (Politikverflechtung) summarises this mutual dependency (see also: Rudzio 1991: 352-359).

As the federal Parliament sets policy standards in many areas that are administered by the Länder, the regional chamber of $\mathrm{P}_{\sigma}$ arliament, the Bundesrat, acts as a powerful direct representative of the governments of the Länder. ${ }^{52}$ The consent of the Bundesrat is required for bills that affect the Länder. The Bundesrat may object to all other legislation, which can be overruled by the Bundestag, the lower house of Parliament (Art. 77). In case of conflict between the two houses, a mediation committee is formed of 16 members from each house. In the overwhelming majority of cases, the mediation committee is able to facilitate an agreement (Hesse and Ellwein 1997: 318-319).

\subsection{Revenue Assignment}

With regard to the assignment of revenue sources, a central question is whether levels of government should have independent access to tax bases, or whether revenues should be shared. While the first option maximises the autonomy and independence of different governments, the latter option allows for a uniform tax regime across the country.

\subsubsection{Canada}

The Constitution Act (section 91(3)) grants the federal Parliament the power to levy indirect as well as direct taxes, while the provinces are confined to direct taxation. ${ }^{53}$ In practice both levels have a wide range of revenue-raising powers. The federal government mainly relies on revenue from personal and corporate income taxes, as well as the Goods and Services Tax (GST) levied since the beginning of 1991 (Krelove et al 1997: 209). The provinces impose both personal and corporate income taxes, the collection of which is administered by the federal government (with the exception of Quebec's) on the basis of

52 The Prime Minister of each Land is a member of the Bundesrat, in addition to other delegates. The delegates of a particular Land always vote as a block, not individually. 
tax collection agreements. A 1982 constitutional amendment allowed provincial use of taxes on natural resources. Judicial interpretation in Canada further allows the provincial use of retail sales tax, which all provinces collect, by deeming it to be a direct tax levied on the consumer but collected by the seller.

\subsubsection{Germany}

The Grundgesetz (Art. 106) applies the separation principle to most taxes, but the sharing principle to the most important taxes, namely income tax, corporation tax and VAT (Spahn and Föttinger 1997: 228-230). ${ }^{54}$ The Bund and the Länder share equally the revenue from income tax and corporation tax. The respective shares of the Bund and the Länder in the revenue from the VAT are determined by federal legislation requiring the consent of the Bundesrat. This arrangement introduces an element of flexibility in accordance with changing needs and circumstances. ${ }^{55}$ Both the Bund and the Länder receive two thirds of their income from shared taxes. Tax legislation remains centralised (Hesse and Ellwein 1992: 83). ${ }^{56}$ Local governments raise their own revenue mostly from service charges, property taxes and a local business tax ${ }^{57}$. They also receive 15 per cent of personal income tax, on the basis of the income tax paid by their population.

Table 6: Tax Sharing in Germany (1997)

In per cent of revenue collected

\begin{tabular}{lccc}
\hline Joint tax & Federal & Provincial & Local \\
\hline Personal income tax & 42.5 & 42.5 & 15.0 \\
Corporate income tax & 50.0 & 50.0 & 0 \\
Value-added tax & $50: 5$ & 49.5 & 0 \\
Local business tax & 5 & 15 & 80.0 \\
\hline
\end{tabular}

Souree. Grundgesetz Spahn and Föttinger (1997).

Note. $*$ The shares result from a formula apportionment and are rounded.

\footnotetext{
${ }^{53}$ Direct taxation is taxation on individuals or companies, which is paid directly by them or through their employer. Usually, it is levied on wealth or income. Indirect taxation is levied on expenditure.

54 Interestingly, the former Minister of Finance, Theo Waigel, supported a separation of revenues and powers of taxation. This would have left indirect taxation to the Bund and direct taxation to the Länder (Der Spiegel, 10 August 1998).

55 In the period between 1995 and 1996, the share of the Bund was lowered from 56 to 50.5 per cent, consequently raising the Länder share to 49.5 per cent. The adjustment was made necessary by changes concerning the taxability of child maintenance grants, which caused a lower tax yield for the Länder (Laufer and Münch 1997: 165-167).

56 Local governments in Germany have some discretion with regard to the setting of tax rates.

57 The local business tax was initially a three-part tax on local business capital, capital returns, and wage sums paid (Biehl 1994: 87). The latter part of the business tax was abolished in 1980, while the federal government in 1997 initiated moves to do away with its working capital component (Spahn and Föttinger 1997: Footnote 4). About 15 per cent of the revenue collected from the local business tax are passed on to the Lainder, and 5 per cent to the Bund.
} 


\subsection{Intergovernmental Transfers and Grants}

The design of intergovernmental transfers and grants requires the following choices: To what extent should differences in wealth between regions be equalised? Should equalisation include a redistribution process from rich to poor regions? To what extent should the central government influence subnational expenditure through conditional grants?

\subsubsection{Canada}

The Constitution Act (1982) commits the federal government to equalisation "to ensure that provincial governments have sufficient revenues to provide reasonably comparable levels of public services at reasonably comparable levels of taxation" (section 36). These federal grants are based on a formula that compares the tax capacity of each province to a representative standard. ${ }^{58}$ If a province's total revenue-raising ability falls short of this standard, its per capita revenue is raised to the standard level through federal equalisation payments. Only Alberta, British Columbia and Ontario do not receive equalisation grants under this system. French-speaking Quebec is the single largest recipient of equalisation payments in absolute terms (Hobson and St-Hilaire 1993).

Inter-provincial redistribution outside the equalisation programme but through the "spending power" of the federal government includes the Canada Health and Social Transfer (CHST) in support of health care, post-secondary education and social assistance programs. ${ }^{60}$ One condition attached to the CHST is that there be no period of minimum residency with respect to social assistance. In the area of public health the only other condition is provincial maintenance of the criteria and conditions spelled out in the Canada Health Act (1984). ${ }^{61}$ The "Framework to Improve the Social Union for Canadi-

\footnotetext{
58 First, the amount of revenue that each province could raise (at national average tax rates) is calculated for each kind of revenue that provinces and their local governments typically levy. Second, each province's overall ability to raise revenues from these sources is compared to that of the five provinces making up a representative standard: Quebec, Ontario, Manitoba, Saskatchewan and British Columbia. For details on the formula, see: Krelove et al (1997: 215-220) and Shah (1994b: 49-50).

59 Its "spending power" allows the federal govemment to spend money in areas assigned to provinces. 60 The Canada Health and Social Transfer replaced federal transfers for social assistance under the Canada Assistance Plan (CAP), and for health and post-secondary education under Established Programs Financing (EPF) on 1 April 1996.

61 Health is a provincial competence in Canada. However, broad political consensus made it possible for the federal Parliament to pass this act, which established some essential criteria for the entire country. Due to this consensus, the act has not been challenged in the constitutional court, although the federal Parlia-
} 
ans", signed on 4 February 1999 by all governments except Quebec, promises some funding predictability in return for a provincial commitment to nation-wide priorities.

Table 7: Major Federal Transfers to Provinces in Canada (1997-8) In millions of Canadian dollars unless othenvise indicated

\begin{tabular}{lccccc}
\hline Province & CHST & Equalisation & Total transfers & $\begin{array}{c}\text { Total transfers } \\
\text { (dollars per capita) }\end{array}$ & $\begin{array}{c}\text { Total transfers } \\
\text { (\% of estimated } \\
\text { revenues) }\end{array}$ \\
\hline Newfoundland & 500 & 933 & 1351 & 2400 & 42 \\
Prince Edward Island & 115 & 185 & 281 & 2000 & 37 \\
Nova Scotia & 800 & 1144 & 1848 & 1950 & 42 \\
New Brunswick & 635 & 883 & 1434 & 1870 & 32 \\
Quebec & 6799 & -3878 & 10283 & 1400 & 28 \\
Ontario & 9082 & - & 9082 & 800 & 20 \\
Manitoba & 952 & 1030 & 1894 & 1650 & 35 \\
Saskatchewan & 828 & 238 & 964 & 900 & 19 \\
Alberta & 2128 & - & 2128 & 750 & 15 \\
British Columbia & 3166 & - & 3166 & 800 & 15 \\
Total & 25005 & 8291 & 32431 & - & - \\
\hline Sourt Webitfon
\end{tabular}

Source. Website of the Canadian Federal Department of Finance.

Notes. The CHST has two components: a cash transfer and a tax point transfer. Tax point transfers involve the federal government reducing its taxes to allow provinces to raise theirs by an equal amount. Equalisation associated with tax point transfers under CHST appears in both the Equalisation and CHST figures. Total transfers are adjusted to avoid double counting, and may not add due to rounding.

\subsubsection{Germany}

Equalisation between the Länder is achieved through two mechanisms (Deutsches Institut für Wirtschaftsforschung 1996). First, the Grundgesetz (Art. 107) allows 25 per cent of the Länder share of the yield of the VAT to be used to pay supplementary tax shares to those Länder with a below average tax capacity. The aim is to uplift the fiscal capacity per inhabitant of poor Länder to 92 per of the Länder average. Second, horizontal fiscal equalisation shifts funds from rich to poor Länder (Shah 1994b: 50-52).$^{62}$ The aim of horizontal equalisation is to achieve a minimum fiscal capacity of 95 per cent of Länder average.63 Unconditional supplementary grants from the Bund fill the remaining gap between the fiscal capacity of an individual Land and the Länder average.

In addition, the Bund is responsible for financing tasks delegated to the Länder (e.g. student support). It also provides conditional grants for "especially important investments",

ment transgressed its assigned powers. The federal level penalised the use of hospital "user fees" and doctors" "extra billing" with the Canada Health Act by deducting appropriate amounts from the transfers to the provinces. This forced the provinces to harmonise their legislation with federal demands (Leslie 1988: 52). 62 Over a transitional period, from unification until the beginning of 1995, the new Länder did not participate in the existing horizontal equalisation scheme (Bundesministerium der Finanzen 1997). 
such as the construction of roads, social housing and hospitals (Art. 104a), and towards the financing of the shared responsibilities (Art. 91a and 91b).

Table 8: Effects of Equalisation in Germany (1996)

Fiscal capacity per capita in per cent of Länder average

\begin{tabular}{lccc}
\hline & Before equalisation & $\begin{array}{c}\text { After horizontal } \\
\text { equalisation }\end{array}$ & $\begin{array}{c}\text { After additional } \\
\text { federal grants* }\end{array}$ \\
\hline Hessen & 117.2 & 104.1 & 104.1 \\
Baden-Würtemberg & 108.8 & 102.9 & 102.9 \\
Bayem & 108.6 & 102.8 & 102.8 \\
Hamburg & 107.9 & 102.8 & 102.8 \\
Nordrhein-Westfalen & 106.4 & 102.2 & 102.2 \\
Schleswig-Holstein & 99.6 & 99.8 & 103.3 \\
Rheinland-Pfalz & 96.2 & 97.6 & 103.6 \\
Niedersachsen & 95.4 & 97.1 & 101.1 \\
Saarland & 89.7 & 95.0 & 104.5 \\
Brandenburg & 85.1 & 95.0 & 120.0 \\
Sachsen & 84.5 & 95.0 & 119.0 \\
Thüringen & 84.0 & 95.0 & 120.6 \\
Sachsen-Anhalt & 83.9 & 95.0 & 120.6 \\
Mecklenburg-Vorpommern & 83.5 & 95.0 & 121.4 \\
Bremen & 79.2 & 96.4 & 105.0 \\
Berdin & 72.3 & 95.0 & 114.6 \\
\hline Sourc Bundesmis. & &
\end{tabular}

Source. Bundesministerium der Finanzen (1998: 34-35).

Note. * Excluding budget consolidation grants to Bremen (DM 1.8 billion) and Saarland (DM 1.6 billion).

\subsection{Borrowing Arrangements}

Finally, governments require access to borrowing to finance capital projects. But the question remains how subnational access to borrowing should be regulated: Should there be rules, co-ordinating procedures or centralised control? Or should subnational borrowing be subject to market discipline only?

\subsubsection{Canada}

Both the federal and provincial governments can borrow funds for current and capital purposes without constitutional or other legal restrictions. They are also not required to balance their budgets annually and are only subject to market discipline, since one or more international investment firms rate their debt. In recent years, some of these ratings have been downgraded, reflecting increasing public concern about the accumulation of debt. Debt targets are now used as part of consolidation efforts. Municipal governments

63 The population figures of cities with Länder status are weighed 35 per cent higher than those of "normal" Länder to compensate for the expenses incurred due to their small size. For instance, substantial spillovers 
are required by the provinces to balance their current account budgets, while capital expenditure is subject to varying restrictions imposed by the different provinces (Krelove et al 1997: 220-222).

\subsubsection{Germany}

The Grundgesetz (Art. 115(1)) restricts the Bund to borrowing for capital expenditure, which is referred to as the "golden rule". Similar restrictions are enshrined in the constitutions of the Lander. Local capital expenditure may also be financed through loans, subject to Länder supervision (Spahn and Föttinger 1997: 236-239).

\subsection{Chapter Conclusion}

This chapter demonstrated the impact that the choice for a particular model of regional government has on fiscal arrangements in a country. In the divided model (as in Canada), national and regional governments pursue their functions as independently as possible and directly access sources of revenue. In the shared model (as in Germany), the emphasis is on concurrent responsibility and shared sources of revenue. It is possible to explain the choice between these models by factors such as the approach to federation ("bottom up" versus "top down" approach to federation), the age of the constitutional framework (older versus recent federations) and the prevalence of ethnic cleavages (ethnically heterogeneous versus ethnically homogeneous federations). Nonetheless, economic considerations are to some extent reflected in both cases. For example, there is congruence with regard to the assignment of some expenditure functions with a national-scope (e.g. defence and foreign affairs). However, the extent of decentralisation is greater in Canada, on both the expenditure and revenue side. It is an interesting question whether, in general, divided models are associated with a higher degree of (expenditure and revenue) decentralisation than shared models. This issue deserves further research. 
Table 9: Models of Regional Government and their Fiscal Arrangements

\begin{tabular}{|c|c|c|}
\hline & Divided model: Comada & Shared model: Germany \\
\hline Fundamental principles & Diversity, dualism and competition. & $\begin{array}{l}\text { Uniformity, integration and co- } \\
\text { operation. }\end{array}$ \\
\hline \multirow[t]{3}{*}{ Expenditure assignment } & $\begin{array}{l}\text { According to policy areas (e.g. health, } \\
\text { education, defence). }\end{array}$ & $\begin{array}{l}\text { According to governmental functions } \\
\text { (regulation and implementation). }\end{array}$ \\
\hline & $\begin{array}{l}\text { Concurrency and joint responsibilities } \\
\text { minimised: Norms and standards de- } \\
\text { termined by level of government to } \\
\text { which policy area is assigned. Separate } \\
\text { federal and provincial administrations. }\end{array}$ & $\begin{array}{l}\text { Concurrency and joint responsibility } \\
\text { emphasised: Federal government sets } \\
\text { norms and standards in many areas, bu } \\
\text { depends on subnational administra- } \\
\text { tions. }\end{array}$ \\
\hline & $\begin{array}{l}\text { No meaningful provincial representa- } \\
\text { tion in national Parliament. }\end{array}$ & $\begin{array}{l}\text { Strong provincial representation in } \\
\text { national Pardiament. }\end{array}$ \\
\hline Revenue assignment & $\begin{array}{l}\text { Direct access to own revenue for levels } \\
\text { of government. }\end{array}$ & $\begin{array}{l}\text { Sharing of revenue sources between } \\
\text { levels of government. }\end{array}$ \\
\hline Equalisation & $\begin{array}{l}\text { Vertical: Equalisation the sole respon- } \\
\text { sibility of the federal govemment (pa- } \\
\text { ternal settlement). Regional disparities } \\
\text { and diversity accepted. }\end{array}$ & $\begin{array}{l}\text { Horizontal: Equalisation based on the } \\
\text { principle of interregional solidarity } \\
\text { (fratemal settlement). Goal to achieve } \\
\text { uniformity of living conditions. }\end{array}$ \\
\hline Borrowing & Separate responsibility. & Common rules. \\
\hline $\begin{array}{l}\text { Possible explanatory } \\
\text { variables }\end{array}$ & $\begin{array}{l}\text { Ethnically heterogeneous. Bottom up } \\
\text { approach to federation. Older consti- } \\
\text { tutional framework (1867). }\end{array}$ & $\begin{array}{l}\text { Ethnically homogeneous. Top down } \\
\text { approach to federation. More recent } \\
\text { constitutional framework (1949). }\end{array}$ \\
\hline
\end{tabular}




\section{CHAPTER 4:}

\section{FISCAL FEDERALISM IN SOUTH AFRICA}

This chapter outlines the design of fiscal federalism in South Africa. It draws mainly on the final Constitution and relevant legislation, budgetary data, as well as a discussion of suggested and actual practices. It also highlights key issues relating to the functioning of the structure of government in the country. Since South Africa's fiscal structures are still evolving, the following analysis is necessarily a snapshot. Nonetheless, it draws together some of the central trends that have emerged since the implementation of the new constitutional framework as from 1997.

In 1997, for the first time, the nine provinces that had been created in 1994 were responsible for drawing up their own bưdgets, within an overall resource envelope, rather than merely managing centrally determined allocations for each spending area. Prior to the 1997-8 financial year, provincial budgets were the sum of centrally determined allocations for various functions. Allocations for specific functions were consolidated in aggregate transfers from the budget vote of the national Department of Finance to each province, supplemented with specific project funds from other national departments or the Reconstruction and Development Programme (RDP) fund. ${ }^{64}$ This process involved a system of centrally steered function committees according to expenditure areas (Hartzenberg 1995).

The 1997-8 budget introduced a system of block grants distributed to the provinces by formula. Conditional grants were introduced in the following year, in conjunction with a more detailed formula for the distribution of funds between provinces. Local government was included in the new system of transfers and grants in 1998. Both local and provincial governments now receive a share of nationally collected revenue, in line with the provisions of the new Constitution. Fundamental adjustments have thus been affected over the past three years, while a number of details remain to be finalised.

\footnotetext{
${ }^{64}$ The RDP was the socio-economic policy framework published by the ANC in 1994 . The programme emphasised two aims: the alleviation of poverty and the reconstruction of the economy (see Lodge 1999: 27-39). The fund financed related projects across the provinces. The effectiveness of this spending has been subject to controversy. In KwaZulu-Natal, for example, a row erupted in October 1998 when it emerged that about R 28 million of RDP funds spent during the 1995-6 and 1996-7 financial years could not be fully accounted for (Business Day, 9 October 1998).
} 


\subsection{Expenditure Assignment}

The key to the division of functions is the classification provided in schedules 4 and 5 of the Constitution. Schedule 4 lists functional areas of concurrent national and provincial legislative competence. Schedule 5 lists functional areas of exclusive provincial legislative competence. Both schedules are divided into two parts, A and B. The former contain the executive functions of provincial governments, the latter the executive functions of local governments. Matters that are not listed in these schedules, the residual, fall under the legislative and executive authority of the national sphere. The following section discusses the division of legislative powers between the spheres, to gain a clear picture of which sphere is responsible for the formulation of policy across various expenditure areas, followed by an analysis of executive responsibilities.

Table 10: Constitutional Assignment of Legislative and Executive Powers in South Africa Schedule 4: Functional areas of concurrent Schedule 5: Functional areas of exclunational and provincial legislative competence sive provincial legislative competence

Part $A$ : Administration of indigenous forests, agriculture, Provincial provincial airports, animal control and diseases, executive casinos, consumer protection, cultural matters, functions disaster management, education excluding tertiary education, environment, health services, housing, indigenous and customary law, industrial promotion, language policy, provincial media services, provincial nature conservation, police, pollution control, population development, property transfer fees, provincial public enterprises, public transport, public works, regional planning and development, road traffic regulation, soil conservation, tourism, trade, traditional leadership, urban and rural development, vehicle licensing, welfare services.

Part B: Air pollution, building regulations, child care Local facilities, electricity and gas reticulation, fire executive fighting services, local tourism, municipal airports, functions municipal planning, municipal health services, municipal public transport, municipal public works, Pontoons, ferries, jetties, piers, harbours, stormwater management systems in built-up areas, trading regulations, water and sanitation services.

Abattoirs, ambulance services, provincial archives, provincial libraries, liquor licences, provincial museums, provincial planning, provincial cultural matters, provincial recreation and amenities, provincial sport, provincial roads and traffic, veteninary services excluding regulation of the profession.

Beaches and amusement facilities, billboards and advertisements in public places, cemeteries, funeral pardours and crematoria, cleansing, control of public nuisances, liquor outlets, facilities for animals, fencing and fences, licensing of dogs, food outlets, local amenities, local sport facilities, markets, municipal abattoirs, municipal parks and recreation, municipal roads, noise pollution, pounds, public places, refuse removal, refuse dumps and solid waste disposal, street trading, street lighting, traffic and parking.

Source. The Constitution of the Republic of South Africa, 1996 (Act 108 of 1996), schedules 4 and 5.

Note. Schedules 4 and 5 contain additional detail, which has been omitted here for the benefit of brevity.

Due to the summary of certain items, alphabetical order could not always be maintained. 


\subsubsection{Assignment of Legislative Powers}

\subsubsection{National, Provincial and Local Legislative Powers}

The national Parliament has the right to pass legislation in any matter, excluding, under normal circumstances, those relating to exclusive provincial competencies (section 44). A provincial legislature may pass a provincial Constitution, in accordance with the national Constitution, pass legislation in those areas that are listed in schedules 4 and 5 , and pertaining to matters that have been delegated to a province through national legislation. Furthermore, a province may delegate a legislative power to a municipal council and recommend legislation to the lower house of the national Parliament, the National Assembly (section 104). Legislating is not a main function of municipalities. A municipality is restricted to passing by-laws when this is necessary for the "effective administration" of its executive functions, i.e. those listed in parts $B$ of schedules 4 and 5 or delegated to it (section 156). A by-law that conflicts with national or provincial legislation is invalid.

Although provinces have substantial law-making powers, they have so far tended not to utilise their legislative "space" to the fullest. ${ }^{65}$ There are two explanations for this. First, many provincial legislatures struggle to legislate beyond the necessary annual appropriations. ${ }^{66}$ This may be due to the fact that the consideration of national legislation and the negotiating of mandates for provincial delegates to the national Parliament are timeconsuming (see section on the participation of provinces in the national law-making process). Hindering factors also include a lack of skilled staff to draft legislation, and the need for provinces to wait for national legislation to be passed so that their legislation would be compatible with it. Second, national norms and standards in the concurrent areas are rather detailed, leaving little to be regulated by provincial legislation (see section on

\footnotetext{
65 The provincial legislatures of Mpumalanga and the Northem Cape passed only two bills in 1997, while sitting for 33 and 36 days respectively. The Westem Cape legislature passed the most bills, 13 in 55 days, followed by KwaZulu-Natal, North West and Gauteng with 11 bills each. The Gauteng legislature sat for 34 days, while the KwaZulu-Natal and North West legislatures sat for 22 days each. The Eastem Cape legislature sat for the 60 days in 1997, the highest number across provinces, and passed nine bills. The Free State and Northern Province legislatures passed seven bills each, while sitting for 32 and 22 days respectively (Business Day, 24 March 1998). By now one may have expected consolidating legislation in areas of provincial competence, and more progress in repealing legislation inherited from the apartheid era. ${ }^{66}$ Some provinces still rely on the assistance of the national Department of Finance for drafting their budgets (Interview: Donian, 8 April 1999). The review of budgets often stretches the ability of provincial legislatures (e.g. Newham 1997). The lack of capacity in some provinces to conduct an efficient legislative process was highlighted when all provincial expenditure in the Eastem Cape from April to August 1998 turned out to have been illegal. The office of Premier Makhenkesi Stofile had omitted to publish the 19989 Appropriation Bill in the Govemment Gazette due to an "oversight" (Business Day, 30 September 1998).
} 
mandates). Welfare is a case in point. Since entitlements are determined at national level, no variation of entitlements can occur across provinces. Provinces are bound to comply administratively with these national requirements.

Only two provinces, in which the ANC did not obtain a majority in the 1994 elections, have so far drawn up their own Constitutions, the Western Cape and KwaZulu-Natal. The Constitutional Court ruled that the Constitution of the Western Cape required some technical adjustments to comply with the national Constitution, which were effected. ${ }^{67}$ Premier Hernus Kriel signed the Constitution of the Western Cape into law on 15 January 1998. Amongst other items, it marked the end of three years of compulsory powersharing between the NP and the ANC in the province (Business Day, 16 January 1998). The Constitution of KuaZulu-Natal was rejected by the Constitutional Court after being drafted in 1996. It was found to usurp powers not accruing to the province according to the national Constitution. ${ }^{68}$ After the 1999 elections, and the formation of a coalition government between the IFP and ANC in the province, the parties agreed to resume talks on the provincial Constitution (Business Day, 21 June 1999). ${ }^{69}$

\subsubsection{Conflict Between Legislation}

In case of conflict between national atıd provincial legislation falling within a concurrent area, national legislation prevails under certain conditions, for instance if it deals with a matter that cannot be regulated effectively at the provincial sphere or that requires uniformity across the nation. Such uniformity must be achieved by prescribing norms and standards, frameworks or national policies. National legislation relating to a concurrent matter also prevails if it is necessary for the maintenance of national security or economic unity, the protection of the common market, the promotion of economic activities across provincial boundaries, to promote equal opportunity or equal access to government services, or the protection of the environment (section 146(2)). National legislation further prevails if it is to prevent unreasonable action by a province that is prejudicial to another or the country as a whole or impedes the implementation of national economic policy (section 146(3)).

${ }^{67}$ Certification of the Constitution of the Western Cape, 1997, 1997 (4) SA 794 (CC) and 1997 (9) BCLR 1167 (CC).

${ }^{68}$ Certification of the Constitution of the Province of KwaZulu-Natah 1996, 1996 (11) BCLR 1419 (CC).

${ }^{69}$ Issues to be raised include the extension of the provincial cabinet, the role and powers of the Zulu monarchy, and traditional leaders. 
While national legislation in the concurrent areas is only to prevail if certain conditions are fulfilled, it is questionable how much legislative power these provisions leave to provinces. While the list of conditions in sections 146(2) and (3) is extensive, it suffices if only one of them is met in order for national legislation to prevail. Nonetheless, the Constitutional Court found that this did not presume in favour of national legislation, as these factors were "objectively justiciable" in a court (Centification Judgement II, para. 155).

The national Parliament may also intervene in exclusive provincial areas by passing legislation if this is required in order to: maintain national security, economic unity or essential national standards; establish minimum standards required for the rendering of services; or prevent unreasonable action by a province which is prejudicial to the interests of another province or to the country as a whole (section 44(2)). The Liquor Bill (1998) was an attempt by the national Department of Trade and Industry to regulate an area that is exclusively assigned to the provinces by the Constitution. This test case has been referred to the Constitutional Court for clarification (Business Day, 17 February 1999).

\subsubsection{Provincial Participation in the National Law-Making Process}

While the national Parliament has very broad legislative powers, the Constitution also provides for the participation of provinces in the national law-making process. The $\mathrm{Na}$ tional Council of Provinces (NCOP) represents the provinces to ensure that provincial interests are taken into account in the national sphere of government. It participates in the national legislative process and provides a forum for issues affecting the provinces (section 42(4)). The NCOP plays an important role in approving national legislation that affects the provinces (section 76). Although it does not have an absolute veto, the vote of the NCOP in case of section 76 legislation represents the composite result of a vote of each provincial legislature. To over-ride an NCOP decision on such legislation, the $\mathrm{Na}$ tional Assembly requires a two-thirds majority. Legislation deemed not to affect the provinces (section 75) and money bills (section 77$)^{70}$ require only a non-binding recommendation from the NCOP to the National Assembly (Wehner 1997b), as the assembly can choose to overrule the council's vote with a simple majority.

\footnotetext{
${ }^{70}$ A money bill is defined as a "bill that appropriates money or imposes taxes, levies or duties".
} 
The Constitution (section 78) provides for a mediation committee in case of conflict between the National Assembly and the NCOP with regard to section 76 legislation. This body is closely modelled on the German example. ${ }^{71}$ In contrast with the frequent use of the mediation committee in Germany, however, the South African conflict-resolution mechanism has not been utilised so far. This may be largely due to the fact that the same party, the ANC, enjoys a substantial majority in both houses. So far, the closest a situation has come to necessitating the use of the mediation committee was in November 1998. Changes to the Liquor Bill (1998) by the Select Committee on Trade and Industry were endorsed by the NCOP, across party lines, and to the dismay of the national Minister of Trade and Industry, Alec Erwin. The Portfolio Committee on Trade and Industry in the National Assembly subsequently voted to concur with the council's amendments, thus avoiding the possibility of mediation being needed to resolve differences over the bill between the two houses (Business Day, 6 November 1998).

The Constitution also envisages the participation, when necessary, of organised local government in the proceedings of the NCOP (sections 67 and 163). Up to ten part-time representatives designated by organised local government may participate, but not vote (Bhabha 1997). The South African Local Government Association (SALGA) has participated in discussions on matters affecting local government. ${ }^{72}$

The NCOP has only been in existence since 1997, and it has been a challenge to ensure the smooth running of its affairs (Murray and Simeon 1998, Sehurutshe and Newham 1998, Van Heerden 1997). The effective co-ordination of various role-players and communication processes had to be achieved (NCOP 1999a, b and c). Provinces had to respond to the demands of participating in the national Parliament, by attempting to reconcile the tension between their own legislative activities and the requirement to develop mandates for national legislation. The complexity of national bills often does not allow members of provincial legislatures to give their NCOP delegates a considered mandate (Friedman 1999: 46). Nonetheless, the NCOP passed 108 bills in 1997, 27 of which were bills affecting the provinces. The council amended nine section 75 bills and 12 section 76

\footnotetext{
71 The mediation committee consists of nine members of the National Assembly and one delegate from each of the nine provincial delegations in the NCOP. Agreement on a version of a bill is reached when at least five members of each set of represêntatives agree.

72 For instance in the negotiations leading up to the approval of the intervention by the govemment of the Eastem Cape in the municipality of Butterworth. This case is dealt with in detail in the section on monitoring and intervention.
} 
bills (NCOP 1998). The NCOP also used its right to initiate legislation with the Organised Local Government Bill (1997). It remains to be seen whether such initiatives will become more commonplace in the future.

Friedman (1999: 46) concludes that the NCOP "might become a dynamic part of our political process if parties would relax their internal discipline and allow delegates to vote according to their perceived provincial interests rather than the party line. They do not. So, instead of becoming a site for shifting alliances and bargaining between politicians with constituencies, the NCOP becomes another rubber stamp, as wasteful and irrelevant as the old Senate."

\subsubsection{Assignment of Executive Responsibilities}

\subsubsection{National, Provincial and Local Executive Responsibilities}

While the national Parliament has broad powers to set policy standards, the provinces have extensive executive responsibilities. They are not only the principle agents for implementing provincial legislation, but also national legislation within the concurrent areas. The administration of matters outside the functional areas listed in schedules 4 and 5 can be delegated to a province through national legislation (section 125). Any other functions fall under the responsibility of the national government. Municipalities are assigned to administer the local government matters listed in part $B$ of schedules 4 and 5 , as well as any matter delegated to them by national or provincial legislation (section 156). This section also stipulates that the national and provincial governments must assign to a municipality, by agreement and subject to any conditions, any of the functions listed in parts A of schedules 4 and 5 if local provision would enhance efficiency.

In practice the national government is mainly responsible for economic services (finance, trade and industry, labour), protection services (police, defence, justice, prisons), housing and general administration. The responsibilities of provinces include primary and secondary education, health and welfare services, as well as provincial roads and local economic development. Municipalities provide essential basic services, such as electricity, water and refuse removal. Even though there is a lack of complete data, available documentation indicates that the bulk of local authority expenditure is undertaken by the four 
metropolitan areas in Gauteng, greater Cape Town and Durban (Siebrits 1997: 36-40). While the focus of local government expenditure remains on the provision of basic services, overall expenditure reprioritisation has had a substantial impact on provincial expenditure patterns. The interaction between general expenditure trends and provincial expenditures is explored further in the following sections.

\subsubsection{General Expenditure Trends}

General government expenditure has been subject to reprioritisation since the democratic elections in 1994. These developments have been made more explicit with the introduction of the Medium Term Expenditure Framework (MTEF).$^{73}$ An overview of consolidated national and provincial expenditure during this decade reveals that defence spending has been subject to drastic cuts, offsetting increases for policing and prisons. The "icon of oppression" (Walker 1999: 8) during the apartheid years is projected to consume only 5.2 per cent of budgeted expenditure at the beginning of the new millennium, down from 11.3 per cent at the beginning of this decade. Declining defence expenditure is reflected in the national budget, since defence is the executive responsibility of the national government. Social expenditure - comprising education, health and welfare - will receive increasing shares of the budget. As provinces have administrative respunsibility in these areas, this trend highlights the important role of provinces in social development. The seeming dip in housing expenditure is misleading, as until 1997 the poorer provinces were not able to fully disburse the money allocated by the national department, which resulted in substantial rollovers of unspent funds. Expenditures on smaller functions are projected to decline over the next financial years. The most disturbing trend is that debt-servicing costs are projected to take up 21.4 per cent of the budget in the 2000-1 financial year, up from 12.5 per cent in 1990-1. The rising debt servicing costs are a constraint on social spending and developmental expenditures. At the same time, some expenditures cannot be reduced any further without threatening the viability of certain departments. This reduces the possibility for further reprioritisation by shifting funds between functions (Department of Finance (1999: 133):

\footnotetext{
${ }^{73}$ The MTEF brought about a system of three-year rolling budgets, in line with identified priorities and commitments. Under the new system, the broad spending intentions and the underlying economic and policy framework are outlined annually in the "Medium Term Budget Policy Statement", which was published for the first time in December 1997 (Department of Finance 1997b and 1998c). Three-year estimates for each department and summaries by function are now included in the budget, and the policy priorities and objectives of government are outlined for the next three years (Walker 1999).
} 
"Shifts in the distribution of spending will be more moderate over the next few years. Infrastructure and development programmes have gained considerable momentum and spending trends now closely match budgeted allocations. The emphasis in extending and improving service delivery will increasingly fall on better organisation and management within departments and gains through improved efficiency and more effective delivery of services. In taking forward the nation's economic and social development commitments, the emphasis is now on improved service delivery within the broad structure of spending priorities..."

Figure 2: Consolidated National and Provincial Expenditure Trends (1990-2000)

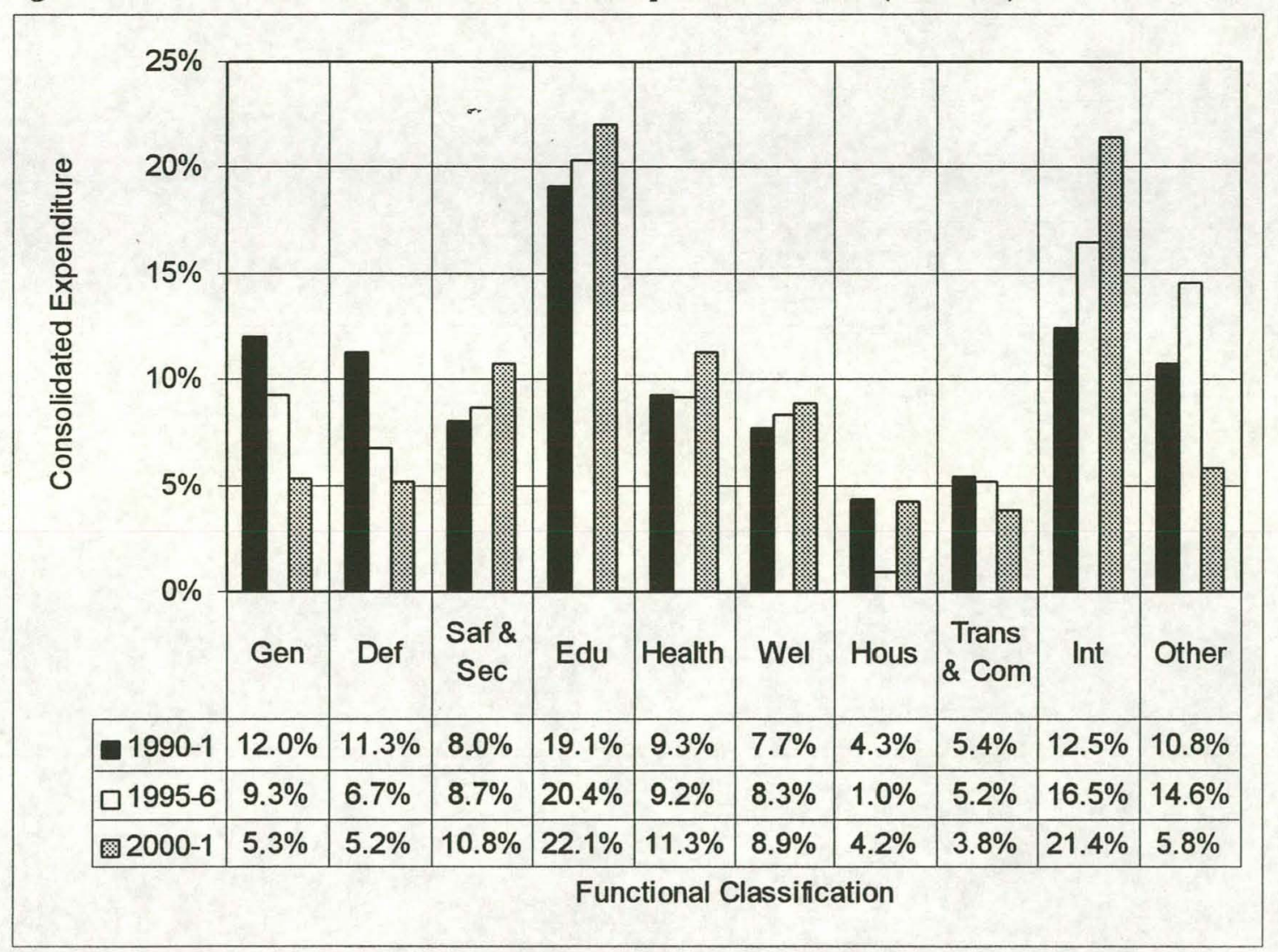

Sources: Department of Finance (1998a: Table 3.11 and 1999: Table 5.8).

Notes: Data for 1990-1 and 1995-6 is based on the Auditor-Generals reports for the national and provincial governments. Data for $2000-1$ is based on medium term expenditure estimates.

The following abbreviations are used: Gen $=$ General, Def $=$ Defence, Saf $\&$ Sec $=$ Safety and Security,

Edu $=$ Education, Wel $=$ Welfare, Hous $=$ Housing, Trans $\&$ Com $=$ Transport and Communications, Int $=$ Interest. 


\subsubsection{Provincial Expenditure Trends}

Provincial expenditure data reveals several trends. ${ }^{74}$ Most notably, budgeted provincial expenditure has been subject to a 2.9 per cent real decrease between 1996-7 and 1999-0. As the following sections will show, this is a result of decreasing shares transferred from the national revenue pool, and decreases in the collection of own revenue.

Table 11: Total Provincial Budgets 1996 Rands

\begin{tabular}{lccc}
\cline { 2 - 4 } & $\mathbf{1 9 9 6 - 7}$ & $\mathbf{1 9 9 9 - 0}$ & \% change \\
\hline Eastem Cape & 14208923 & 12939023 & $-8.9 \%$ \\
Free State & 5700379 & 5413871 & $-5.0 \%$ \\
Gauteng & 11982019 & 12765335 & $6.5 \%$ \\
KwaZulu-Natal & 15330797 & 15280652 & $-0.3 \%$ \\
Mpumalanga & 4769589 & 4869431 & $2.1 \%$ \\
Northem Cape & 1834298 & 1829724 & $-0.2 \%$ \\
Northern Province & 10052725 & 9734178 & $-3.2 \%$ \\
North West & 6906958 & 6383986 & $-7.6 \%$ \\
Western Cape & 8882160 & 8157878 & $-8.2 \%$ \\
Total & 79667848 & $\mathbf{7 7 3 7 4 0 7 8}$ & $-2.9 \%$ \\
\hline
\end{tabular}

Source. Data provided by the Idasa: Budget Information Service.

Note. The substantial increase in Gauteng is a result of conditional grants for academic hospitals.

The share of social expenditures (on health, education and welfare) in provincial budgets has risen steadily, and now makes up more than 80 per cent. According to an executive agreement reached in the Budget Council ${ }^{75}$ provinces pledge to spend 85 per cent of their budgets on social expenditures. Most provinces, however, have not reached this standard. The introduction of provincial finance reserves in order to budget for contingencies squeezes the resources that are left over for exclusive provincial concerns. Overall, little provincial expenditure is directed to areas where provinces have full control over how money is spent. Differences in the composition of spending across provinces indicate varying needs. For instance, the share of the welfare budget is lowest in Gauteng, the economic centre of the country, with a younger population than the rural provinces where recipients of welfare grants are concentrated. Differences in the composition of provincial spending may also arise from varying costs of providing a service, or differing levels of efficiency between or within provinces (Walker 1999: 11).

\footnotetext{
${ }^{74}$ For independent microanalyses of provincial budgets, please refer to the annual overviews published by the Budget Information Service at Idasa. The following are the overviews of the 1998-9 provincial budgets: Hopley (1998), Makhanya (1998), Msimango (1998), Steyn (1998), Van der Merwe and Van Rensburg (1998), Van Zyl (1998b,c and d), Walker (1998).

${ }^{75}$ This body is dealt with in the section on transfers and grants below.
} 
Figure 3: Consolidated Provincial Expenditure Trends (1995-2001)

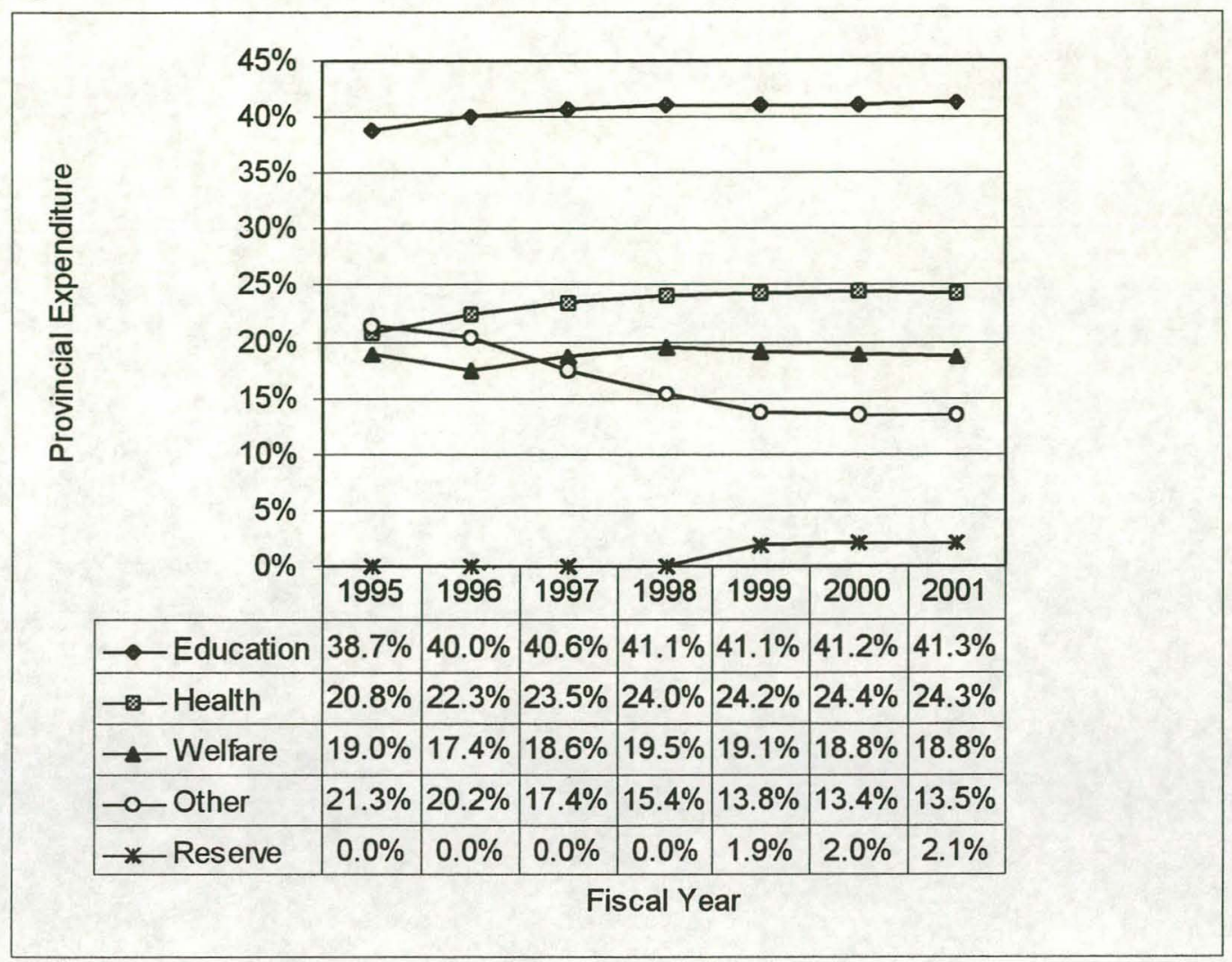

Source: Calculations based on data from the Department of Finance (1999: Table 4.1).

Figure 4: Social Spending in 1999-0 Provincial Budgets

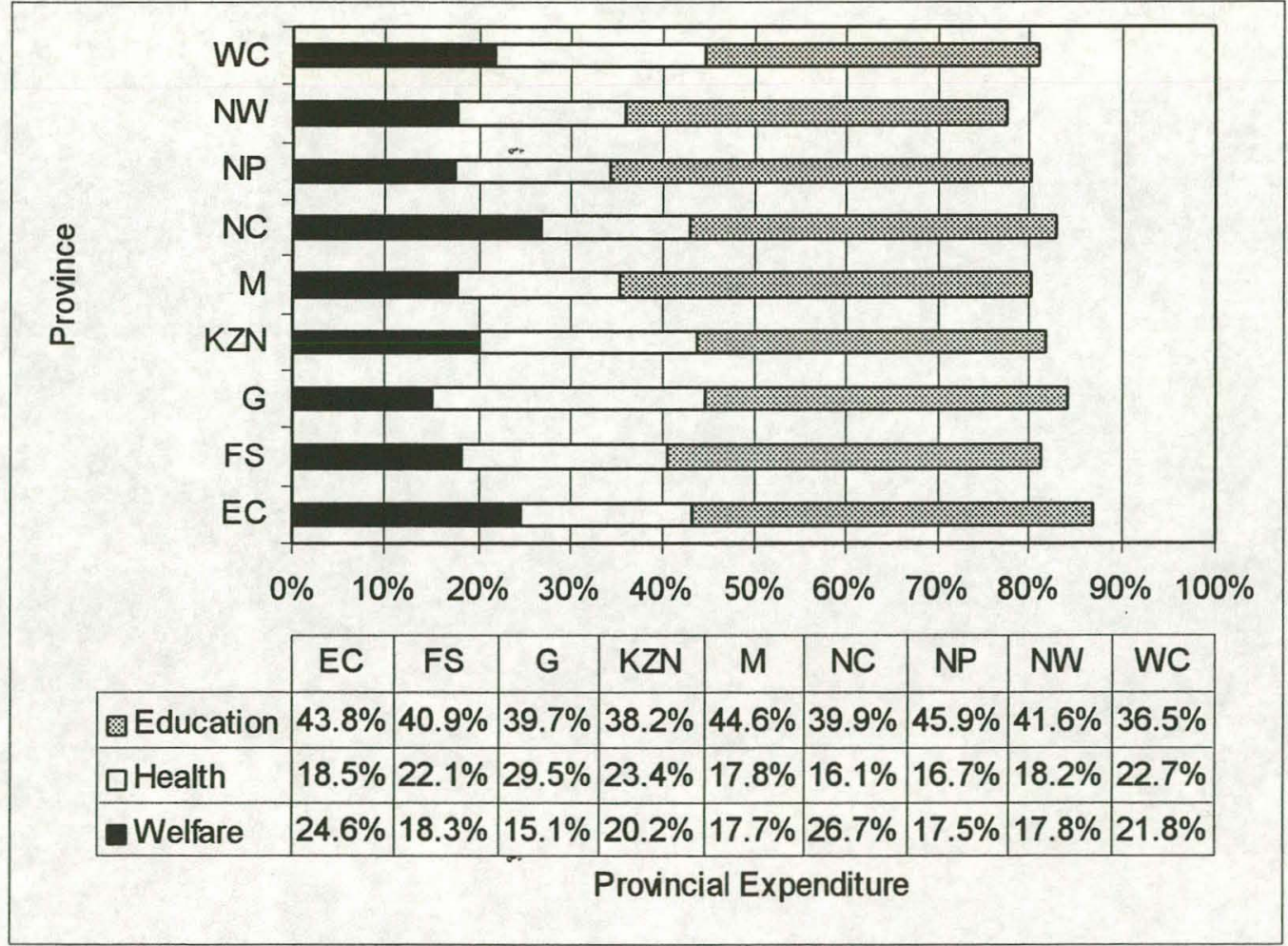

Source: Provincial budgets, compiled by the Idasa: Budget Information Service. 


\subsection{Mandates}

In the social expenditure areas, provincial discretion is limited through national norms and standards. In order for this system to work optimally, it is important that the national sphere takes into account the financial and administrative ability of the provinces to implement national legislation. The Ncholo Report pointed out (Ministry for the Public Service and Administration 1997: 14): "Many National departments create new policies without considering how they are to be implemented. The unwritten expectation is that the provinces will make the necessary financial and organisational arrangements. There appears to be an assumption at national level that policy will automatically become activity." Examples cited include free health care for nursing mothers and infants and the provision of abortion on demand. One provincial health administrator comments that these policies were implemented "overnight", and that a definite increase in the use of health care services has been recorded as a result (Interview: Abdullah, 17 June 1998). The exact impact of such legislation is, however, difficult to ascertain in most provinces due to the lack of adequate and consistent patient records.

The recent Public Finance Management Act (1999), as amended, contains a section dealing with "unfunded mandates" (section 35). The act prescribes that draft national legislation that assigns any obligation to a provincial government must project the financial implications for the province in an accompanying memorandum. This is the first time that unfunded mandates are given legal recognition (Wehner 1999b). The act does not require that the respective national department cover the cost imposed on provincial departments. Nonetheless, the provision should enhance the information available to the NCOP for its deliberations. In practice much will depend on the detail and accuracy of such costing. Other observers have noted that the NCOP has no access to independent bodies which could review such costing, and mediate in case of conflicting opinions (Interview: Donian, 8 April 1999). Unlike in some other countries (e.g. Gullo and Kelley 1998), Parliament in South Africa lacks research capacity in budgetary matters (Krafchik and Wehner 1998b). Although provinces raised the issue, a review of financial mandates contained in existing legislation is not foreseen by the act. ${ }^{76}$ The example of the health sector indicates that this would be a valuable area for further research. 


\subsection{Personnel Expenditure}

Apart from reprioritisation, increased social expenditure reflects rising personnel expenditure across the provinces. Provinces employ about 60 per cent of all civil servants. While personnel expenditure comprised 53 per cent of total provincial expenditure in 1995-6, budgeted expenditure for the 1999-0 financial year projects this share at almost 60 per cent. The ability of provinces to control their personnel expenditure, however, is limited: First, provincial wages are subject to decisions in the Central Bargaining Chamber. Second, it is the obligation of the national government to finalise an affordable retrenchment tool that would enable provinces to cut their number of civil servants.

Provinces have increasingly shown discontent with the delays in the formulation of a national policy on retrenchments. The former Premier of the Free State, Ivy MatsepeCasaburri, noted that the issue "is a big problem because we have to abide by national policy and there is no national policy" (Business Day, 18 September 1998). Skills audits in the provinces and national departments are hoped to ensure that service delivery will not be affected by any retrenchments (Business Day, 10 February 1999). A process involving voluntary severance packages proved costly and was characterised by a disproportionately high number of much needed experienced personnel, with private sector prospects, leaving the civil service (see also: MacGregor et al 1998).

A question mark has been over the number of excess civil servants. While in 1995 this figure had been put at 55000 (Business Day, 2 October 1998), the number of redundant public servants was estimated to total 35000 in May 1999 (Business Day, 13 May 1999). ${ }^{77}$ The then Director-General for the Public Service, Paseka Ncholo, reported that the overall size of the public service had decreased by 10 per cent since 1994 due to the voluntary severance packages scheme, natural attrition and resignations.

The example of the health sectorillustrates the personnel problems of provinces. About 90 per cent of provincial budgets for primary and secondary education are taken up by personnel expenditure (mainly on teachers' salaries). This leaves few resources to main-

\footnotetext{
76 The author observed the deliberations of the NCOP's Select Committee on Finance on the bill.

77 By 1999 audits had been completed in a number of provinces. These identified 8000 "supemumaries" in the Northem Province, 3000 in the North West, 22000 in the Eastem Cape, 12 in the Northem Cape and none in the Westem Cape. In the case of the Eastem Cape, the filling of about 8000 vacancies could reduce the total number to 14000 .
} 
tain schools, pay telephone and electricity bills, or purchase learning materials (Sunday Independent, 6 June 1998). The national Department of Education decided that "there were enough teachers but they were in the wrong places" (Van Niekerk and Ludman 1999: 64). The department prescribed student-teacher ratios (40-1 for primary schools and 35-1 for high schools) and in 1996 announced a "rightsizing" strategy. This required each province to compile a list of "excess" teachers and offer them either retrenchment packages or redeployment to other schools where there was a shortage. The department prescribed that hiring was to draw on this list of excess teachers. One of the many setbacks occurred when Grove Primary School in Cape Town successfully took the minister to court in 1997 over the requirement to hire teachers from the list. By the end of 1997 the department abandoned the exercise and announced that provinces would from now on work out their own ratios. A new redeployment process entailed provincial education departments dividing their personnel expenditure budgets by the average teacher salary to determine the number of teachers they could afford (Business Day, 18 November 1998). Redeployment has since proceeded at various speeds across the provinces. ${ }^{78}$

After several years of increasing shares of personnel expenditure in the provinces, a stabilisation at just below 60 per cent of consolidated provincial expenditure has been predicted for the following years (Department of Finance 1999: Table 4.1). To halt the existing trend, however, provinces require mechanisms to control their wage bills. An effective retrenchment tool may provide such action space, as may decentralised wage bargaining structures. Without empowering provinces to control their personnel expenditure the projected stabilisation of the wage bill may turn out to be over-optimistic.

\subsection{Capital Expenditure}

As a direct result of the need to finance rising personnel expenditure, the average budgeted capital expenditure share of provincial budgets has decreased by almost half since 1996. Decreasing capital expenditure, especially in health and education, represents a threat to strategies that aim to extend services to communities in historically disadvantaged areas and bring about a more equitable access to services (Interview: Abdullah, 17

\footnotetext{
${ }^{78}$ In KwaZulu-Natal, for example, the acher and student numbers changed as "ghost" teachers and leamers were discovered. Different interpretations of the process by department officials and schools also led to problems. Finally, it was detected late in the process that the provincial education department had
} 
June 1998). Thus, as Simkins (1997) remarks, the control of provincial service numbers and wage levels is central to ensuring more rapid growth in delivery.

Table 12: Budgeted Provincial Capital and Personnel Expenditure Per cent of total provincial budget

\begin{tabular}{lcccccccc} 
& \multicolumn{3}{c}{ Capital Expenditure } & \multicolumn{3}{c}{ Personnel Expenditure } \\
\cline { 2 - 8 } & $\mathbf{1 9 9 6 - 7}$ & $\mathbf{1 9 9 7 - 8}$ & $\mathbf{1 9 9 8 - 9}$ & $\mathbf{1 9 9 9 - 0}$ & $\mathbf{1 9 9 6 - 7}$ & $\mathbf{1 9 9 7 - 8}$ & $\mathbf{1 9 9 8 - 9}$ & $\mathbf{1 9 9 9 - 0}$ \\
\hline EC & $\mathbf{7 . 1} \%$ & $6.0 \%$ & $\mathbf{2 . 8} \%$ & $\mathbf{3 . 2} \%$ & $\mathbf{5 2 . 3} \%$ & $50.7 \%$ & $58.5 \%$ & $\mathbf{5 7 . 9} \%$ \\
FS & $\mathbf{8 . 2} \%$ & $9.6 \%$ & $\mathbf{5 . 7 \%}$ & $\mathbf{1 . 9} \%$ & $53.2 \%$ & $53.2 \%$ & $58.2 \%$ & $64.3 \%$ \\
G & $8.4 \%$ & $7.5 \%$ & $7.3 \%$ & $7.6 \%$ & $52.3 \%$ & $50.7 \%$ & $60.0 \%$ & $58.5 \%$ \\
KZN & $10.9 \%$ & $7.2 \%$ & $2.5 \%$ & $5.9 \%$ & $50.1 \%$ & $54.9 \%$ & $58.8 \%$ & $57.7 \%$ \\
M & $13.4 \%$ & $8.0 \%$ & $\mathbf{4 . 9} \%$ & $4.9 \%$ & $47.2 \%$ & $54.0 \%$ & $60.0 \%$ & $60.0 \%$ \\
NC & $8.0 \%$ & $4.9 \%$ & $5.5 \%$ & $3.6 \%$ & $45.4 \%$ & $46.0 \%$ & $\mathbf{4 9 . 8 \%}$ & $49.2 \%$ \\
NP & $7.9 \%$ & $8.7 \%$ & $4.4 \%$ & $3.1 \%$ & $55.6 \%$ & $60.0 \%$ & $\mathbf{6 5 . 4 \%}$ & $65.2 \%$ \\
NW & $9.1 \%$ & $10.7 \%$ & $6.0 \%$ & $5.2 \%$ & $43.3 \%$ & $52.6 \%$ & $58.2 \%$ & $60.6 \%$ \\
WC & $5.0 \%$ & $5.0 \%$ & $4.5 \%$ & $3.4 \%$ & $51.6 \%$ & $52.7 \%$ & $\mathbf{5 5 . 1} \%$ & $56.3 \%$ \\
Average & $\mathbf{8 . 7} \%$ & $\mathbf{7 . 5} \%$ & $\mathbf{4 . 9} \%$ & $\mathbf{4 . 7} \%$ & $\mathbf{5 0 . 1} \%$ & $\mathbf{5 2 . 8} \%$ & $\mathbf{5 7 . 4} \%$ & $\mathbf{5 8 . 3} \%$ \\
\hline So
\end{tabular}

Source. Provincial budgets.

Note. Data provided by the Idasa: Budget Information Service.

\subsubsection{Monitoring and Intervention}

\subsubsection{Ensuring the Fulfilment of an Executive Obligation}

The Constitution (section 125) stipulates that a province has executive authority only to the extent that it has the administrative capacity to assume effective responsibility. The national government is required to assist provinces to develop the necessary capacity. Any dispute concerning the administrative capacity must be referred to the NCOP for resolution within 30 days. When a province cannot or does not fulfil an executive obligation, the national executive may intervene "by taking any appropriate steps to ensure fulfilment of that obligation" (section 100). This may include issuing a directive, or assuming direct responsibility for the relevant obligation. The latter is only allowed to the extent that it is necessary to maintain or enforce national minimum standards, to maintain economic unity or national security, or to prevent unreasonable action by a province. In the case of direct intervention the NCOP must be notified and approve any such action. The council has the duty to review the intervention regularly and advise the national executive accordingly. 
The Constitution also allows a provincial executive to intervene in local government affairs should this be necessary to ensure the fulfilment of an executive obligation (section 139). The NCOP is required to approve and monitor such interventions, and to make recommendations to the relevant provincial executive. National legislation that may regulate the process established by these sections is still outstanding. The Department of Constitutional Development has been conducting research into this matter (Department of Constitutional Development 1999: 7).

\subsubsection{Intervention in Practice}

So far, only the national Department of Finance has utilised the provisions of section 100. When the Eastern Cape and KwaZulu-Natal recorded considerable budget overruns in the 1997-8 financial year, a R 1.5 billion "life-line" in form of an advance was granted under this section, which allowed conditions to be attached (Business Day, 2 April 1998, Department of Finance 1999: 94).$^{79}$ These conditions included a provincial undertaking to remain within budget, providing a detailed spending plan and supplying monthly progress reports. Early in 1999 the national Department of Finance invoked section 100 for a third time when it emerged that the Free State expected to run a deficit of about R 170 million for the 1998-9 financial year.

Section 139 enabled the Eastern Cape provincial government to take over the municipality of Butterworth in March 1998 by dispatching administrators to take charge of local authority functions (Business Day, 21 April 1998). Lessons still have to be drawn from this precedent. For instance, the process revealed the need for formalised procedures to regulate the consideration and approval of intervention by the NCOP (Franks 1998). The previous Chairperson of the NCOP, Patrick Lekota, subsequently announced that a new unit is to be set up within the council to oversee interventions, and to ensure their effectiveness (Business Day, 9 April 1999). ${ }^{80}$ Another question is whether intervention can ensure delivery. In the case of Butterworth, the municipality continues to be plagued by leadership battles similar to those that led to intervention (Cullinan 1999: 7-9). Mean-

\footnotetext{
79 While provincial expenditure overruns in the 1997-8 financial year occurred not only in these two provinces, KwaZulu-Natal and the Eastem Cape were the only ones that applied for additional funds from the national government.

${ }^{80}$ The likelihood of increased intervention in local government affairs due to the executive failure of a number of authorities was confirmed in interviews conducted by the author with the Heath Special Investigating Unit (Interview: Rich and Visagie, 29 March 1999) and the FFC (Interview: Donian, 8 April 1999).
} 
while, traffic lights are not working, refuse is not being removed, and local roads are in dire need of repair.

\subsubsection{Corruption}

The debate around intervention according to section 100 and 139 has been partially informed by reports on the work of the Heath Special Investigating Unit, an independent body investigating incidents of corruption ${ }^{81}$ in all spheres of government. Data provided by the unit may at first sight be interpreted as supporting a need for direct national intervention in the affairs of some authorities. A breakdown of the value of cases by province shows a concentration of incidents in the Eastern Cape and KwaZulu-Natal.

Table 13: Corruption Cases by Proviñce

\begin{tabular}{lcl} 
& Number of cases & \multicolumn{1}{c}{ Value } \\
\hline Eastem Cape & 7641 & R 727642932.58 \\
Free State & 26 & R 188033424.93 \\
Gauteng & 3 & R 14253702.00 \\
KwaZulu-Natal & 2042 & R 34970970.96 \\
Mpumalanga & 52 & R 423324642.11 \\
North West & 240 & R 106726744.91 \\
Northem Cape & 35 & R 199213977.23 \\
Northem Province & 19 & R 5155194888.00 \\
Westem Cape & 3 & R 81000.00 \\
National Government & 50 & R 1501958043.62 \\
Total & $\mathbf{1 0 1 1 1}$ & R 8351400326.34 \\
\hline
\end{tabular}

Source. Provided by the Heath Special Investigating Unit on 29 March 1999.

Note. The value of cases has been subject to a protracted dispute between the Heath Special Investigating Unit and the national Department of Finance. The department commissioned a report by the AuditorGeneral in April 1999 after the Minister of Finance, Trevor Manuel, disagreed with Judge Heath's claim that the unit had recovered about R 42 million in cash and assets and had prevented the loss of R 848 million. The report largely verified the unit's work (Business Doy, 1 July 1999).

However, this data should be interpreted with caution. Factors that need to be taken into consideration include the duration for which the Heath Unit has been functioning in the various provinces and the existence of internal anti-corruption units in some of the

\footnotetext{
${ }^{81}$ Section 2 of the Special Investigating Units and Special Tribunals Act (1996) allows the president to refer matters to the unit on grounds of any alleged serious maladministration in state institutions; improper or unlaw ful conduct by its employees; unlawful appropriation or expenditure of public money or property; unlaw ful, irregular or unapproved activities relating to state property; intentional or negligent loss of public money or damage to public property, corruption in state institutions; or unlawful or improper conduct by any person against the interests of the public. A case is investigated by the unit once this has been authorised by means of a presidential proclamation. Refer to Klitgaard (1998) for an introductory analysis of the nature of corruption. Klitgaard proposes that corruption equals monopoly plus discretion minus accountability $(C=M+D-A)$. Corruption has been identified as a major obstacle to development (Gray and Kaufmann 1998). For an introductory essay on political comption in South Africa, see Lodge (1999: 56-67).
} 
provinces. ${ }^{82}$ Judge Willem Heath has also noted the varying quality of the working relationships his unit has been able to establish with the provinces. For instance, he criticised the Western Cape for being "extremely slow" in referring corruption cases to his unit (Business Day, 12 January 1999). Indicating a will to uncover corruption, the North West province has installed a "Hotline on Fraud and Corruption", situated in the office of the Premier, Popo Molefe (Sowetan, 6-May 1998). These examples illustrate the different ways with which corruption is dealt with by individual provincial governments.

Due to such factors, the Heath Unit itself has rejected suggestions that the breakdown of cases is a reflection of the actual incidence of corruption. Instead, the unit points to the fact that its investigating teams for the different provinces are roughly of equal size, indicating that investigators consider corruption to be an omnipresent problem. When asked whether the unit considered corruption to be a greater problem at subnational than at national level, the representatives noted the link between corruption and procurement procedures. As procurement procedures are multiplied at subnational level, there are also more opportunities for corruption (Interview: Rich and Visagie, 29 March 1999).

In other provinces, such as Mpumalanga, the existence of provincial press agencies may contribute to a disproportionately high media coverage of corruption. Thus, the description as "Mamparalanga" (Mail \& Guardian, 16 October 1998), in recognition of a succession of scandals hitting the province, may be misleading if construed to imply that corruption is a more serious problem here than elsewhere.

Lodge (1999: 59) further suggests that by the 1980s corruption was wide-spread in the central government as well as the homeland administrations, and thus cannot be described as a new phenomenon: "From 1948 ethnic favouritism characterised all civil service recruitment and promotion. Government loans and resources were equally invoked by ethic and political considerations."

\footnotetext{
${ }^{82}$ For instance, the high number of corruption cases in the Eastem Cape reflect the fact that the unit was active in this province since 1995, before its mandate was extended to the national level. Many of the cases attributed to the Eastem Cape, therefore, were carried over from the unit's previous mandate.

${ }^{83}$ According to the Oxford Dictionary of South African English, a "mampara" or "mompara" describes "a fool, greenhom or incompetent: also a mode of address (abusive)".
} 


\subsubsection{Capacity}

Some commentators have expressed concerns about the capacity of some provinces to address basic needs (e.g. Rapoo 1995: 9-11, Walker and Van Zyl 1999). ${ }^{84}$

Table 14: Provincial Profiles According to the 1996 Census

\begin{tabular}{ccccccc}
$\begin{array}{c}\text { Popula- } \\
\text { tion (thou- } \\
\text { sands) }\end{array}$ & $\begin{array}{c}\% \text { of total } \\
\text { population }\end{array}$ & $\begin{array}{c}\% \text { living in } \\
\text { urban ar- } \\
\text { eas }\end{array}$ & $\begin{array}{c}\% \text { without } \\
\text { schooling }\end{array}$ & $\begin{array}{c}\% \text { unem } \\
\text { ployed }\end{array}$ & $\begin{array}{c}\% \text { of house- } \\
\text { holds with } \\
\text { tap inside } \\
\text { dwelling }\end{array}$ & $\begin{array}{c}\% \text { of house- } \\
\text { holds using } \\
\text { wood for } \\
\text { cooking }\end{array}$ \\
\hline 6303 & $15.5 \%$ & $36.6 \%$ & $20.9 \%$ & $48.5 \%$ & $24.7 \%$ & $38.0 \%$ \\
2634 & $6.5 \%$ & $-68.6 \%$ & $16.1 \%$ & $30.0 \%$ & $40.6 \%$ & $9.3 \%$ \\
7348 & $18.1 \%$ & $97.0 \%$ & $9.5 \%$ & $28.2 \%$ & $67.7 \%$ & $0.9 \%$ \\
8417 & $20.7 \%$ & $43.1 \%$ & $22.9 \%$ & $39.1 \%$ & $39.8 \%$ & $29.7 \%$ \\
2801 & $6.9 \%$ & $39.1 \%$ & $29.4 \%$ & $32.9 \%$ & $37.3 \%$ & $26.0 \%$ \\
840 & $2.1 \%$ & $70.1 \%$ & $21.7 \%$ & $28.5 \%$ & $50.0 \%$ & $18.5 \%$ \\
4929 & $12.1 \%$ & $11.0 \%$ & $36.9 \%$ & $46.0 \%$ & $17.8 \%$ & $63.6 \%$ \\
3355 & $8.3 \%$ & $34.9 \%$ & $22.7 \%$ & $37.9 \%$ & $30.6 \%$ & $20.7 \%$ \\
3957 & $9.7 \%$ & $88.9 \%$ & $6.7 \%$ & $17.9 \%$ & $76.4 \%$ & $4.5 \%$ \\
40584 & $\mathbf{1 0 0} \%$ & $\mathbf{5 3 . 7 \%}$ & $\mathbf{1 9 . 3} \%$ & $\mathbf{3 3 . 9} \%$ & $\mathbf{4 4 . 7 \%}$ & $\mathbf{2 3 . 0} \%$ \\
\hline
\end{tabular}

Source. Statistics South Africa (1998).

1994 saw the amalgamation of the various administrations inherited form the former South African government, self-governing territories and the "independent" homelands. As employers of roughly 60 per cent of civil servants, the newly created provinces bore the brunt of this challenge. The former homeland structures are unevenly distributed across the nine provinces, which has contributed to the polarisation of provincial administrative abilities. ${ }^{85}$ Wehner (1998b: 23) comments: "The absurdity of such demarcation lies in the fact that those provinces which are historically advantaged by apartheid's system of geographical resource allocation, especially the Western Cape and Gauteng, were spared large-scale incorporation of ailing homelands with a surplus of unskilled and often incompetent civil servants." As a result, underdeveloped and rural provinces not only display the greatest needs, but are also expected to operate within disproportionate capacity constraints due to their inherited personnel and administrative infrastructure. The Premier of the Northern Province, Ngoako Ramathodi (1998) summarises the challenges faced by his province:

\footnotetext{
${ }^{84}$ Stuart (1997) notes that available analytical tools to measure public sector efficiency in South Africa cannot be utilised yet, as the necessary public sector output data is not yet being generated. It is thus difficult to objectively assess the efficiency of certain departments and governments.

${ }^{85}$ The former Transkei and Ciskei are now part of the Eastern Cape; KwaZulu part of KwaZulu-Natal; Qwa Qwa and a part of Bophuthatswana incorporated in the Free State; Venda, Gazankulu and Lebowa part of the Northem Province; four blocs of Bophuthatswana incorporated in North West; KwaNdebele part of Gauteng, and Kangwane and a small section of Lebowa included in Mpumalanga (Welsh 1994).
} 
"We inherited three homelands and bits and pieces of a so-called "white province", which for all practical purposes could have been situated on four different planets. We have to merge four systems of bookkeeping, four sets of personnel records and four different standard operating procedures, and our critics expect of us to undo five decades of bad administration and disregard for the needs of the majority of the population within four years."

\subsubsection{Intervention and Co-operative Government}

Whether increased intervention or a determined exercise in capacity building is the answer to these challenges is open to debate. Comparative evidence suggests that intervention powers are not unique to South Africa, but that their use has often been accompanied by controversy. ${ }^{86}$ However, these powers must be considered in conjunction with other constitutional provisions. Most notably, chapter 3 binds all spheres of government to the "principles of co-operative government and intergovernmental relations" (section 41). Under these provisions, all spheres of government and their organs must: preserve the peace, national unity and the indivisibility of the republic; respect the constitutional status, institutions, powers and functions of the other spheres; not usurp powers or functions; not encruach on the geographical, functional or institutional integrity of government in another sphere; and co-operate with one another. They are even obliged to avoid legal proceedings against one another by exhausting all other possible avenues of conflict resolution before approaching a court. If a court is not satisfied that this requirement was fulfilled, it may refer a dispute back to the organs of state involved.

Placed early in the text, before the allocation of powers and functions to the different spheres is outlined, the provisions of chapter 3 represent a set of overarching guiding principles for the conduct of governmental activities. The Department of Constitutional Development (1999: 10) interprets these provisions "to place an obligation on the three

${ }^{86}$ The Constitution of the Federal Republic of Brazil (1988) contains an entire chapter dealing with intervention (chapter VI). Article 355 of the Constitution of India (1950) obliges the central govemment to protect the states against external aggression and "internal disturbance". The following article 356 outlines provisions in case of failure of the "constitutional machinery" in the states. The central govemment view has been that the Constitution allows it to act "according to its own perception of the situation", as noted in a recent speech by the Union Home Minister, L. K. Advani (Hindu, 23 January 1999). As intervention is a common but highly controversial feature in India, the states are in favour of incorporating more detailed advice as to 
spheres of government to put the national interest first and to co-operate with each other, to support each other and to avoid destructive competition over the political and economic resources of the country". ${ }^{87}$ This notion indicates that the Constitution envisages a collaborative partnership between the spheres, which limits the possibility of intervention in a manner that would not be conducive to restoring the capacity of authority in question to effectively comply with its executive obligations

\subsubsection{The Controversy Surrounding the Assignment of the Welfare Function}

The Welfare Laws Amendment Act (1997) provides the national Minister of Welfare with the exclusive power to set standards for welfare grants. As a result, provinces act as agents of the central government. While they have no real jurisdiction over the function, welfare grants are reflected in provincial budgets. The provinces spend more that 95 per cent of the total national and provincial expenditure on welfare, and more than 91 per cent of provincial welfare expenditure is used to provide social security (Fitschen 1999).

\subsubsection{Administrative Problems}

In January 1998 the Eastern Cape failed to pay social security grants to 632000 pensioners, leaving them and their dependants without money to buy food. The national government "rescued" the province with an advance of $\mathrm{R} 801$ million, to which stringent conditions were attached. It has been convincingly argued that the root cause for the Eastern Cape welfare crisis was that the allocation to the province was not sufficient to allow it to meet growing social security commitments ${ }^{88}$ - a nationally determined entitlement (Van Zyl 1998a). Nonetheless, the experience of the "Eastern Cape pensions crisis" has given rise to a debate around the assignment of the welfare function.

how the centre should determine when the government of a state could not function in accordance with the Constitution. Also refer to Wehner (1999a: 9-10).

87 The department has been working on a White Paper on Intergovemmental Relations for the past two years in order to flesh out the practical meaning of chapter 3 . This policy framework will have to avoid overly rigid requirements that may become a long-term straightjacket, but should create conditions that encourage and facilitate mutual trust and co-operation (Watts 1997: 28).

${ }^{88}$ For the previous fiscal year, when the welfare budget was still administered by the national department, the provincial department had submitted an estimate of $R 3,2$ billion based on the number of beneficiaries $(630000)$ at that stage. However, the department had received only $R 2,2$ billion, less than in the preceding year. The 1996-7 under-funding resulted in overspending by the national welfare department and not by the provincial govemment. The increase of 1.7 per cent in provincial spending on welfare in the 1997-8 
A related problem has hindered the effective planning and control of the function, as "ghost" beneficiaries have inflated provincial welfare expenditure. The "ghosts" are typically deceased pensioners whose relatives continue to draw their welfare benefits. ${ }^{89}$ At one stage, the then Minister of Welfare, Geraldine Fraser-Moleketi, estimated that about 20 per cent of the three million welfare beneficiaries were "associated with irregularities" (Business Day, 10 February 1998). Data irregularities are increasingly being detected by checking the names of beneficiaries against the population register of the Department of Home Affairs. Some provinces have attempted to reregister all pensioners and beneficiaries to eliminate fraud and irregularities. ${ }^{90}$

\subsubsection{Possible Solutions}

The Public Service Commission released its "Report on an Investigation into the Rendering of Social Security" in February 1998. The commission endorsed the status quo: a system in which the national department is responsible for developing norms and standards, while the provincial departments would be responsible for day-to-day administration. However, the report left open where the responsibility for budgeting should be located, with the national or provincial departments (Barberton 1998).

The former Minister for Provincial Affairs and Constitutional Development, Valli Moosa, favoured the centralisation of the welfare function. Welfare grants would be reflected in the national budget (Buisiness Day, 9 February 1999).

To the contrary, the FFC has argued that centralisation is only one of the available options. The commission (FFC 1998b: 15) recommends that provinces be responsible for all aspects of social security grants, which would result in the possibility of different rates or eligibility rules, in order to ensure fiscal autonomy and accountability.

\footnotetext{
provincial budget, an adjustment made by the province after welfare became its responsibility, was not sufficient to cover the existing gap between resource allocation and actual expenditure need.

${ }^{89}$ More than 70000 of these were eliminated from the social security grant system during the 1998-9 financial year alone, resulting in savings of close to $\mathrm{R} 282$ million (Business Day, 19 February 1999). Cases of teenage "pensioners" have also been reported (Mail \& Guardian, 19 February 1999). Other irregularities include the duplication of names and names with multiple identity numbers.

${ }^{0}$ The Westem Cape, for example, revived such a process in October 1998 after a similar initiative two years earlier had not been completed (Cape Argus, 12 October 1998). In the Northem Province, a number of lawsuits forced the provincial department to abandon an attempt to reregister recipients of pensions and disability grants (Mail é Guardian, 15 January 1999).
} 
A middle path has also been suggested (Barberton 1998). This would see the national department developing a welfare formula to determine each province's share of the total welfare budget according to cleaned-up beneficiary data. The resources would be taken out of the pool of nationally collected revenue before revenue-sharing, a practice referred to as "top-slicing". ${ }^{11}$ Provinces would then have access to the savings from efficiency gains, or pay for poor performance.

It would seem that the current disjuncture between policy-making and financial responsibility has caused inefficiency. Any changes should ensure that budgeted amounts are fully aligned with the expenditure requirements for welfare grants in each province, on the basis of cleaned-up beneficiary data.

\subsection{Revenue Assignment}

\subsubsection{National Revenue}

The main sources of tax revenue in 1998-9 were personal income tax (42 per cent of total), VAT (24 per cent) and company ${ }^{92}$ tax (11 per cent) (Department of Finance 1999: Table 6.15). As tax assignment in South Africa remains centralised, these constitute the main contributions to the national revenue pool.

\subsubsection{Provincial Revenue}

Although the Constitution allows provincial legislatures to impose taxes, levies and duties, this does not apply to incomé tax, VAT, general sales tax, rates on property or customs duties (section 228). The Constitution requires that provincial taxation powers be regulated in terms of national legislation, taking into account any recommendations by the FFC. This legislation is still outstanding.

The collection of provincial revenue, mainly derived from fees, has declined in recent years, from 5.6 per cent of total provincial revenue in 1995-6 to 3.8 per cent in 1999-0.

\footnotetext{
${ }^{91}$ This practice will be further discussed in the discussion of the vertical division of revenue.
} 
One reason for this decline is a lower collection rate for user fees in hospitals due to poor accounting and billing systems. Hospitals have limited incentive to improve the collection of user fees, as these funds accrue to the province rather than the contributing hospital. The national Department of Health and the Budget Council have initiated steps to improve provincial revenue collection (Department of Finance 1999: 93). Provincial initiatives have also been announced. For example, the KwaZulu-Natal Member of Executive Council (MEC) ${ }^{93}$ for Finance, Peter Miller, has appointed a team to bolster revenue collection in the province and outlined plans to provide an incentive for agencies to collect more revenue than was budgeted, by allowing them to keep any excess revenue (Business Day, 19 March 1999).

One possibility for provinces to increase their own revenue is to find new revenue bases. Despite the fact that the constitutionally required national framework legislation is still outstanding, two provinces have recently introduced new taxes. These initiatives may indicate frustration with the slow process of implementing the provincial revenue-raising powers contained in the Constitution. The Gauteng MEC for Finance, Jabu Moleketi, caused some controversy with the announcement, in his 1999-0 budget speech, of the introduction of a 5 per cent bed levy in the province in October 1999. The levy will be based on bed nights sold in the province (Business Day, 26 February 1999). Similarly, the North West MEC for Finance, Martin Kuscus, announced the introduction of a 5 per cent levy on the gross income of bookmakers and totalisators (Business Day, 25 February 1999). The possibility for additional revenue from gambling activities, however, has been hampered by irregularities in provincial casino licensing processes. ${ }^{94}$

The Constitution also allows for flat-rate provincial surcharges on the base of any tax, levy or duty imposed by national legislation, other than corporate income tax, VAT, rates on property or customs duties. This leaves the possibility of a provincial surcharge on the national personal income tax base. Necessary national enabling legislation is still out-

\footnotetext{
${ }^{22}$ Gold mines and other mines are taxed separately. While tax on gold and other mines constituted 8 per cent of tax revenue in 1984-5, this share shrank to less than one per cent by 1998-9. This is due to depressed commodity markets, as well as tax allowances in the system (Department of Finance 1999: 169). ${ }^{93}$ MECs are the provincial equivalents of ministers in the national cabinet.

${ }^{94}$ Corruption allegations against senior provincial politicians and relating to the licensing process were muted, amongst others, in Gauteng (Financial Mail, 19 February 1999) and the Westem Cape (Mail \&o Guardian, 12 March 1999). As a result, it has been speculated that the national Ministry for Trade and Industry has plans to exercise more central control over gambling due to "the perception that provincial gaming boards were too susceptible to political influence" (Business Day, 19 May 1999).
} 
standing. In 1998 the Katz Commission ${ }^{95}$ questioned the capacity of the South African Revenue Service (SARS) to administer a system of provincial surcharges on personal income tax. Instead, it favoured a provincial surcharge on the national fuel levy. The FFC (1998: 25-36), on the other hand, has been recommending the implementation of a surcharge on personal income tax to promote democratic and fiscally accountable government in the provinces. The provincial surcharge would be "piggy-backed" on the national personal income tax. The FFC suggests the creation of tax room ${ }^{96}$ by the national government in order to ensure that there is no increase in the overall tax burden, to be phased in over a period of six years, up to seven percentage points of the personal income tax base. Such a system would increase provincial own revenue while reducing the envelope of intergovernmental transfers and grants. Thus, there would be no decrease of revenue accruing to the national government. Contrary to the Katz Commission, the FFC was confident that sufficient collection capacity exists at the central level ${ }^{97}$ to successfully implement a surcharge. The introduction of the surcharge would reduce the existing imbalance between provincial expenditure and revenue assignment.

\subsubsection{Local Revenue}

The Constitution allows municipalities to levy rates on property and surcharges on fees for services (section 229). Service charges are the main sources of operating income for local governments, followed by property rates. Most authorities buy goods and services in bulk from public entities or private companies and derive income from reselling these goods and services to households: The Constitution further allows that, if authorised by national legislation, a municipality may impose other taxes, levies and duties that may be appropriate. This possibility is constrained by the prohibition of a local income tax, VAT, general sales tax or customs duty. However, the "establishment levy" of the former regional services councils, now a source of revenue for metropolitan and district councils, is in essence and despite its name a general sales tax based on the turnover (gross income generated by sales) of business enterprises. The constitutionality of this tax has yet to be tested (Gildenhuys 1997: 89).

\footnotetext{
${ }^{95}$ The official name of the commission is the "Commission of Inquiry into certain Aspects of the Tax Structure of South Africa".

${ }^{96}$ Creating tax room defines the process by which the national govemment reduces its share of a tax in order to make it available to subnational jurisdictions in the form of own revenues. It is an attempt to prevent an increase in the overall tax burdef while allowing subnational governments to increase own revenues.

${ }^{97}$ The FFC envisages the centralised collection of revenue derived from a provincial surcharge.
} 
Currently about 95 per cent of budgeted local operating expenditure is covered by own revenue. This average figure, which includes the metropolitan spending centres, hides enormous discrepancies. Many small rural councils have no viable tax base, for instance due to the absence of property tax revenue (Wehner 1998a: 6). The Katz Commission recommended framework legislation to enable local governments to impose property tax in a coherent fashion, wherever they may be situated (Business Day, 30 November 1998).

A Municipal Property Rating Bill is expected to be tabled in the near future.

An issue of continuous concern has been the revenue collection ability at local level. The "Masakhane" campaign was launched by President Nelson Mandela in 1995 with the goal of improving payment for services. ${ }^{98}$ To monitor payment levels, arrears and the effectiveness of credit control (collection) efforts on a continuous basis the Department of Constitutional Development launched "Project Viability" in the same year." Despite these initiatives, local government was owed R 12 billion by March 1999, a figure growing by between R 500 million and R 1 billion a month (Business Day, 18 March 1999). ${ }^{100}$

Redemarcation efforts have been initiated in line with the policy framework for local government (Ministry for Provincial Affairs and Constitutional Development 1997 and 1998). It is expected that the number of municipalities will be reduced substantially. This may even out disparities between the revenue bases of local authorities. ${ }^{101}$ The drive towards the creation of "megacities" in metropolitan areas, by unifying separate substructures into one central administration, is informed by such arguments. ${ }^{102}$ The evening out of revenue bases, however, cannot address the problem of non-payment.

\footnotetext{
${ }^{98} \mathrm{By}$ the end of apartheid, most municipalities in black areas were ungovernable and bankrupt. Since they were regarded as illegitimate structures by the people under their jurisdiction, a widespread boycott of payments for services prevailed: "While local authorities are now legitimate, they have to reverse the antagonistic rules engraved by decades of strugge" (Wehner 1998a: 4).

99 This information is derived from questionnaires that are sent out to the chief executive officers of municipalities. In 1997 responses were made compulsory. Nonetheless, there are still non-responding municipalities, most of them rural councils with limited capacity to respond to the questionnaires.

${ }^{100}$ Gauteng topped the list of debtors with R 6 billion, followed by the Westem Cape, KwaZulu-Natal, the Eastem Cape and the Northem Province, with R 1.9 billion, 1.1 billion, 1 billion and 109 million respectively

101 The existing local boundaries were in many instances the outcome of a highly politicised demarcation process. Cameron (1996), in his analysis of the Western Cape metropolitan area substructures, highlights how the current demarcation was driven by electoral concems rather than developmental considerations. 102 Some commentators have argued in favour of maintaining a two-tier structure for urban areas (Cape Metropolitan Council et al 1997, Ahmad 1996).
} 


\subsection{Intergovernmental Transfers and Grants}

Because the assignment of revenue sources remains centralised, the Constitution establishes an elaborate system of intergovernmental transfers and grants. Local government and each province are entitled to a share of revenue raised nationally to enable them to provide basic services and perform their functions (section 227). They may also receive grants from the national government, either conditionally or unconditionally. The Constitution prohibits the deduction of additional revenue raised by provinces or municipalities from their share. Equally, there is no obligation on the national government to compensate provinces or municipalities that do not fully utilise their revenue bases.

\subsubsection{The Concept of Equitable Shares}

Central to the South African revenue-sharing regime is the "equitable share" concept established in the Constitution (section 214). The Constitution requires that national legislation must determine the equitable division of revenue raised nationally among the national, provincial and local spheres of government. Such legislation must also determine each province's equitable share of the provincial share of that revenue; any other allocations to provinces, local government or municipalities from the national government's share of that revenue; and any conditions on which those allocations may be made. Section 214 goes further in that it demands that this legislation must take into account: the national interest; provisions for the national debt and other national obligations; the objective needs and interests of the national government; the need to ensure that subnational governments are able to provide basic services and perform their functions; the fiscal capacity and efficiency of subnational governments; their developmental and other needs; economic disparities within and among the provinces; obligations of subnational governments in terms of national legislation; the desirability of stable and predictable allocations of revenue shares; the need for flexibility in responding to emergencies or other temporary needs, and other factors based on similar objective criteria. The Constitution requires that this legislation may only be enacted after the nine provincial governments, organised local government and the FFC have been consulted. Any recommendations by the FFC have to be considered. 


\subsubsection{The Role of the Financial and Fiscal Commission}

These provisions envisage an important role for the $\mathrm{FFC}^{103}$, which reflects a desire to depoliticise the revenue-sharing process (Mokgoro 1994, Dollery 1998). The Constitution establishes the FFC to make recommendations envisaged in the Constitution or national legislation to Parliament, provincial legislatures and any other authorities determined by national legislation (section 220). The Commission is independent and subject only to the Constitution and the law, and must be impartial. The commissioners are appointed by the President, and include a chairperson and a deputy chairperson ${ }^{104}$ who are full-time members, nine persons nominated by the provinces, two persons nominated by organised local government and nine other persons (section 221). The FFC must report regularly to Parliament and the provincial legislatures (section 222). The Financial and Fiscal Commission Act (1997) supplements these provisions. It regulates the affairs and day-today running of the commission. Amongst others, the act (section 27) guarantees the FFC free access, upon request, to any information it requires for the performance of its functions and which is available to an organ of state or related institutions.

In some instances, the Department of Finance (e.g. 1998b) has criticised the commissions "fairly high level of abstraction", and has tended to describe its own approach as characterised "by a keener concern for the practical implications". It is true that the FFC's documents are not easily accessible to the broader public, which has been subject to criticism (e.g. Wehner 1997c). However, the theoretical grounding of the commission can be attributed to its concern with developing impartial standards.

\subsubsection{The Role of the National Council of Provinces}

The division of revenue between and within the spheres is dealt with annually in the Division of Revenue Bill. This bill is classified as a bill affecting the provinces subject to section 76 of the Constitution, which reserves a potentially important role for the NCOP (Murray 1998). However, in practice, the role of the NCOP in the budgetary process has been limited. A lack of research capacity, limited time, and insufficient access to expenditure information constrain its ability to engage with the budget (Krafchik and Wehner $1998 \mathrm{a}$ and 1998b). Other observers have noted that the Division of Revenue Bill is tabled

${ }^{103}$ The Australian Commonwealth Grants Commission (Craig 1997: 184-185) and the Indian Finance Commissions (Hemming et al 1997: 531-532) fulfil similar functions. 
too late in the process to afford a proactive role to the council, as it has by then been subject to extensive executive negotiations (Ajam 1998).

\subsubsection{The Role of the Budget Council}

Instead, the Budget Council has emerged as perhaps the major new player in the provincial budget process (Ajam 1997). ${ }_{\text {. }}^{105}$ This body is not set up in terms of the Constitution, but was formalised with the Intergovernmental Fiscal Relations Act (1997). The Budget Council meets regularly throughout the year to discuss provincial financial matters. It brings together the Minister of Finance, who chairs the council, as well as the nine provincial MECs for Finance. The same act also establishes the Budget Forum, which consists of the Minister of Finance, the nine MECs for Finance, five representatives from the national local government body, as well as one representative nominated by each provincial local government organisation. The Budget Forum deliberates on matters pertaining to local government finance. Any decisions taken by these bodies with regard to the division of revenue has to be approved by the cabinet. The Intergovernmental Fiscal Relations Act stipulates that a Division of Revenue Bill must be accompanied by a memorandum, explaining the extent to which account was taken of any recommendations by the FFC. ${ }^{106}$

\subsubsection{The Recommendations by the Financial and Fiscal Commission}

The allocation of transfers from the pool of nationally collected revenues entails, first, a vertical division of resources between the spheres of government and, second, a horizontal division amongst different governments within the same sphere. ${ }^{107}$

\subsubsection{Vertical Division}

The FFC's initial recommendations related to the 1997-8 financial year, before local government was included into this revenue-sharing process (FFC 1996). The FFC recommended that provincial allocations be increased gradually as provinces assume their con-

\footnotetext{
104 This position is currently vacant.

105 South Africa has seen a proliferation of executive and administrative intergovernmental bodies (De Villiers 1997b), indicating an emphasis on "executive federalism" (Watts 1990).

106 This memorandum is included in annexure $\mathrm{E}$ of the "Budget Review", which is tabled together with the national budget each year.
} 
stitutionally designated functions, and as security and defence spending at national level decreases and thus frees up extra resources. The FFC (1996: 2) also argued that provincial expenditure required more growth than national expenditure as it was more sensitive to population growth, due to the administrative responsibility of provinces for social services such as health and education.

Table 15: Recommended Vertical Division of Nationally Collected Revenues, plus Provincial Revenues from a Surcharge on the Personal Income Tax Base, Phased in from 1 per cent to 7 per cent Share per sphere in per cent

\begin{tabular}{|c|c|c|c|c|c|c|c|}
\hline & 1996-7* & $1997-8$ & $1998-9$ & $1999-0$ & $2000-1$ & $2001-2$ & $2002-3$ \\
\hline Provincial & 51.85 & 52.35 & 52.85 & 53.35 & 53.85 & 54.35 & 54.85 \\
\hline National & 48.15 & 47.65 & 47.15 & 46.65 & 46.15 & 45.65 & 45.15 \\
\hline Total & 100 & 100 & 100 & 100 & 100 & 100 & 100 \\
\hline
\end{tabular}

Source: Financial and Fiscal Commission (1996: Table 1C).

Notes. Improvements in conditions of service are included in the national share.

* The base year figures derived from budgeted expenditures presented to Parliament on 13 March 1996.

Table 16: Recommended Vertical Division of Nationally Collected Revenues, plus Provincial Revenues from a Surcharge on the Personal Income Tax Base, Phased in from 1 per cent to 7 per cent

Share per sphere in $1996 \mathrm{R}$ millions

\begin{tabular}{lccccccc} 
& $\mathbf{1 9 9 6 - \mathbf { 7 } ^ { * }}$ & $\mathbf{1 9 9 7 - 8}$ & $\mathbf{1 9 9 8 - 9}$ & $\mathbf{1 9 9 9 - 0}$ & $\mathbf{2 0 0 0 - 1}$ & $\mathbf{2 0 0 1 - 2}$ & $\mathbf{2 0 0 2 - 3}$ \\
\hline Provincial & $\mathbf{7 5 2 2 9}$ & $\mathbf{7 8 3 0 6}$ & 81425 & $\mathbf{8 4 6 6 1}$ & $\mathbf{8 8 0 1 9}$ & $\mathbf{9 1 5 0 1}$ & 95113 \\
National & 69919 & 71269 & 72636 & 74022 & 75426 & 76847 & 78285 \\
Total & 145218 & $\mathbf{1 4 9 5 7 5}$ & 154062 & 158684 & 163444 & 168347 & $\mathbf{1 7 3 3 9 8}$ \\
\hline
\end{tabular}

Soume: Financial and Fiscal Commission (1996: Table 1D).

Notes. Improvements in conditions of service are included in the national share.

* The base year figures derived from budgeted expenditures presented to Parliament on 13 March 1996.

The FFC recommended that total annual transfers to local governments be kept equal to their historical volume. The commission proposed the identification of a time period in which backlogs would be addressed, and that the implications of increasing the transfers to local government in order to eliminate backlogs be considered (FFC 1997).

\subsubsection{Provincial Equitable Share and Conditional Grants}

The FFC proposed a formula for the horizontal division of resources among the nine provinces, as it considered a formula more objective and less prone to manipulation by politicians and civil servants. A formula would enable provinces to predict revenues with greater certainty, which in turn would allow them to plan ahead. In order to address historical funding imbalances, the proposed formula aimed to achieve equity in public ex-

${ }^{107}$ In the following analysis, the descriptions of formulas and their components mirror closely those found in the indicated source documents. Due to the technical nature of the content, rephrasing might have distorted the meaning of these descriptions in some instances. 
penditure, in per capita terms, over a period of five years. This would allow all provinces to adjust to the new funding arrangements. Provinces with a shrinking resource envelope would have the necessary time to reprioritise, while those with expanding allocations would have a period in which to build their capacity to handle resources efficiently. Previously over-funded provinces like the Western Cape and Northern Cape would experience a real decrease in funding, i.e. after inflation is taken into account. Other provinces would experience real increases, especially the Northem Province, North West and Mpumalanga. For the 1997-8 fiscal year, provinces would receive unconditional sums which they could allocate as they saw fit. The FFC recommended a review of the formula after three years (Abedian et al 1997: 44-51, FFC 1996). The recommended formula consisted of five components, making up the total allocation to a particular province $(\mathrm{P})$ :

$\mathrm{P}=\mathrm{S}+\mathrm{m}+\mathrm{T}+\mathrm{I}+\mathrm{B}$

The national standards grant $(\mathrm{S})$ aiméd to supply provinces with sufficient funds to provide a minimum standard of services in primary and secondary education and primary and district-level health care. A province's allocation would be dependent on the size of its population eligible for these services and the average cost of providing them at the minimum standard (for instance, in education, the amount of school-aged children and the cost of teaching with a target pupil-teacher ratio of 1:38).

The spillover component $(\mathrm{m})$ was intended to finance those services which are subject to inter-provincial spillover effects. It would be allocated to those provinces with academic hospitals to compensate for the costs of medical training and the provision of specialised health services such as heart transplants, services which benefit other jurisdictions.

The fiscal capacity equalisation grant $(\mathrm{T})$ was based on the notion that each province must be accountable for any spending which would require raising additional revenue. The $T$ grant would complement provincial taxation powers to equalise for varying fiscal capacities (i.e. tax bases). In the absence of the necessary enabling legislation for provincial taxation, a transitionally assigned surcharge (TAS) would act as a proxy for own revenue equal to the tax room created. 
The institutional grant (I) was to cover the cost of running a basic administration in each of the provinces, such as a legislature and provincial executives.

Finally, the basic grant (B) would allow provinces to establish and maintain the institutions necessary to fulfil their constitutional obligations according to their own priorities. Provincial shares were calculated on the basis of the weighted population figures for each province. People living in rural areas were given a weight of 1.25. "Ruralness" was chosen as a proxy for differences in wealth and as an indicator of deprivation with few datarelated problems.

Table 17: Recommended Total Allocation per Province $\mathrm{R}$ millions

\begin{tabular}{lccccccc} 
& $\begin{array}{c}\text { 1996-7 Budget } \\
\text { (Base Year) }\end{array}$ & $\mathbf{1 9 9 7 - 8}$ & $\mathbf{1 9 9 8 - 9}$ & $\mathbf{1 9 9 9 - 0}$ & $\mathbf{2 0 0 0 - 1}$ & $\mathbf{2 0 0 1 - 2}$ & $\mathbf{2 0 0 2 - 3}$ \\
\hline Westem Cape & 8378 & 8753 & 9163 & 9605 & 10078 & 10441 & 10830 \\
Eastem Cape & 13901 & 15162 & 16584 & 18184 & 19981 & 21847 & 23952 \\
Northem Cape & 1769 & 1847 & 1930 & 2017 & 2108 & 2178 & 2249 \\
KwaZulu-Natal & 14546 & 16239 & 18158 & 20360 & 22883 & 25563 & 28644 \\
Free State & 5195 & 5680 & 6233 & 6860 & 7573 & 8307 & 9144 \\
North West & 6450 & 7151 & 7950 & 8863 & 9904 & 11009 & 12273 \\
Gauteng & 11108 & 12284 & 13671 & 15302 & 17218 & 19143 & 21422 \\
Mpumalanga & 4610 & 5124 & 5714 & 6393 & 7173 & 7992 & 8936 \\
Northem Province & 9324 & 10439 & 11711 & 13163 & 14820 & 16607 & 18651 \\
& & & & & & & \\
Provincial govt. & 75292 & 82678 & 91114 & 100747 & 111737 & 123086 & 136101 \\
National govt. & 69919 & 77150 & 85120 & 93902 & 103578 & 114329 & 125981 \\
\hline
\end{tabular}

Soure. FFC (1996: Table 8-7a).

Table 18: Recommended Total Formula Allocation per Province Per cent of total

\begin{tabular}{lccccccc}
\cline { 2 - 8 } & $\begin{array}{c}1996-7 \\
\text { Budget } \\
\text { (Base Year) }\end{array}$ & $1997-8$ & $\mathbf{1 9 9 8 - 9}$ & $\mathbf{1 9 9 9 - 0}$ & $\mathbf{2 0 0 0 - 1}$ & $\mathbf{2 0 0 1 - 2}$ & $\begin{array}{c}\mathbf{2 0 0 2 - 3} \\
\text { Target }\end{array}$ \\
\hline Westem Cape & 11.13 & 10.58 & 10.03 & 9.48 & 8.92 & 8.31 & 7.69 \\
Eastern Cape & 18.46 & 18.38 & 18.30 & 18.22 & 18.15 & 18.16 & 18.18 \\
Northem Cape & 2.35 & 2.23 & 2.12 & 2.00 & 1.88 & 1.76 & 1.64 \\
KwaZulu-Natal & 19.34 & 19.67 & 20.00 & 20.33 & 20.66 & 21.04 & 21.42 \\
Free State & 6.90 & 6.86 & 6.82 & 6.78 & 6.74 & 6.71 & 6.68 \\
North West & 8.57 & 8.63 & 8.70 & 8.77 & 8.84 & 8.94 & 9.06 \\
Gauteng & 14.75 & 14.79 & 14.81 & 14.84 & 14.85 & 14.68 & 14.49 \\
Mpumalanga & 6.12 & 6.19 & 6.25 & 6.31 & 6.38 & 6.44 & 6.50 \\
Northem Province & 12.38 & 12.68 & 12.98 & 13.28 & 13.58 & 13.96 & 14.35 \\
Total & 100.00 & 100.00 & 100.00 & 100.00 & $\mathbf{1 0 0 . 0 0}$ & $\mathbf{1 0 0 . 0 0}$ & $\mathbf{1 0 0 . 0 0}$ \\
\hline Source. FFC (1996: Table 19C). & - & & & & & &
\end{tabular}


Table 19: Recommended Total Grants per Province per Capita $R$ per capita

\begin{tabular}{lccccccc}
\cline { 2 - 7 } & $\begin{array}{c}\text { 1996-7 Budget } \\
\text { (Base Year) }\end{array}$ & $\mathbf{1 9 9 7 - 8}$ & $\mathbf{1 9 9 8 - 9}$ & $\mathbf{1 9 9 9 - 0}$ & $\mathbf{2 0 0 0 - 1}$ & $\mathbf{2 0 0 1 - 2}$ & $\begin{array}{c}\mathbf{2 0 0 2 - 3} \\
\text { Target }\end{array}$ \\
\hline Westem Cape & 2145 & 2196 & 2252 & 2314 & 2379 & 2415 & $\mathbf{2 4 5 5}$ \\
Eastem Cape & 1905 & 2034 & 2177 & 2337 & 2513 & 2690 & 2886 \\
Northem Cape & 2221 & 2289 & 2362 & 2438 & 2515 & 2566 & 2616 \\
KwaZulu-Natal & 1572 & 1718 & 1882 & 2069 & 2279 & 2494 & 2739 \\
Free State & 1718 & 1833 & 1963 & 2109 & 2272 & 2433 & 2613 \\
North West & 1692 & 1830 & 1986 & 2160 & 2355 & 2554 & 2779 \\
Gauteng & 1337 & 1432 & 1542 & 1671 & 1820 & 1959 & 2122 \\
Mpumalanga & 1559 & 1697 & 1854 & 2031 & 2232 & 2436 & 2668 \\
Northern Province & 1679 & 1847 & 2036 & 2249 & 2488 & 2740 & 3023 \\
& & & & & & & \\
Provincial govt. & 1676 & 1799 & 1938 & 2094 & 2269 & 2443 & 2640 \\
National govt. & 1557 & 1679 & 1810 & 1952 & 2104 & 2267 & 2444 \\
\hline
\end{tabular}

Source. FFC (1996: Table 8-7b).

\subsubsection{Local Government Equitable Share and Conditional Grants}

In a separate document, entitled "Local Government in a System of Intergovernmental Fiscal Relations in South Africa", the FFC presented its initial thinking on how to include local government in the revenue-sharing process (FFC 1997, Wehner 1997c). In an attempt to ensure revenue stability and objectivity, the FFC proposed a formula for the horizontal division of the transfers to local government amongst the metropolitan and district councils. The formula intended to address basic needs, by eliminating backlogs and by enabling the poor to purchase the minimum quantities of certain essential services. Three components made up the Intergovernmental Transfer (IGT):

$\mathrm{IGT}=\mathrm{G}+\mathrm{RS}+\mathrm{T}$

A conditional capital grant $(\mathrm{G})$, stemming from the national government's share of revenue raised nationally, would address infrastructural backlogs in line with national development objectives. The allocation to a municipality would be based on the cost to establish access to basic services. The extent of backlog would be indicated by the relative nonprovision of water and sanitation compared to other local units. These indicators were chosen in the absence of other adequate data. The costs for providing the needed infrastructure thus calculated would be spread out over a number of years.

An unconditional operating transfer (RS), stemming from local government's share of revenue raised nationally, was intended to subsidise access to basic services for those who cannot afford to pay for these services. It was based on the cost to the qualifying consumer (i.e. 
household below the poverty line) of a minimum annual water supply and a basic level of sanitation.

A tax capacity (equalisation).component $(\mathrm{T})$ considered the relative ability of the municipal or district council to subsidise the poor under its jurisdiction. If the aggregate wealth of a jurisdiction is equal or more than its aggregate need, it was expected to provide for its own needs.

\subsubsection{Actual Developments}

The recommendations by the FFC are not legally binding. The national government decided not to adopt the commission's recommendations without adjustments.

\subsubsection{Vertical Division}

The Budget Council decided to "top-slice" (subtract) a number of items from the total available government revenue before the vertical split. These amounts are made up of the interest on government debt, projected improvements in the conditions of service (wage increases for civil servants), and carry-through costs for social pensions etc. In 1997-8 the Budget Council recommended that the remainder be divided between the national and provincial spheres in the same ratio as applied in the 1996-7 budget (Abedian et al 1997: 52). As from 1999-0 the top slice also includes an amount set aside as a contingency reserve for the national government.

The analysis of the vertical division is obscured by the fact that the Department of Finance often uses expenditure data when elaborating on the vertical division, rather than nationally collected revenue. The practice of top-slicing further blurs the picture. Since the overwhelming share of government debt was incurred at the national level, this raises the question why debt should be top-sliced, rather than serviced directly from the national government share of revenue. ${ }^{108}$ The following figure shows that the provincial share of nationally collected revenue has been substantially decreased, from 57.6 per cent in 1996-

\footnotetext{
${ }^{108}$ A process of incorporating a debt of $R 14.8$ billion incurred by the former TBVC states and selfgoveming territories into the national government's debt portfolio has largely been completed. $R 13.9$ billion of debt of the former regional authorities also reverted to the national government in 1994, and a further R 5.3 billion are yet to be incorporated (Department of Finance 1999: 78). However, these amounts are relatively small compared with the total govemment debt, which stood at $R 377.4$ billion in 1999 .
} 
$7^{109}$ to 49.7 in 1999-0. By comparison, the FFC had suggested that provinces should receive 53.35 per cent of nationally collected revenue by $1999-0 .{ }^{110}$ Why this "downward shift" in revenue was not implemented is not clear. An official from the national Department of Finance acknowledges that "judgement and political discretion will always play a role in the budget process" (Interview: Momoniat, 10 June 1998). The Department of Finance (1999: 258) elaborates: "The shares allocated to each sphere are a political judgement made by Cabinet. A consultative process generates the information on which this judgement is made."111

In addition, SALGA has questioned the adequacy of the total share allocated to local governments. The association criticises that the Budget Forum is precluded from meaningful participation in this debate, much of which takes place in the Budget Council, and that it remains unclear who was consulted during the consultative process. It describes the local government equitable share as "simply a more rational way of distributing funds which have historically gone to local government. This approach fails to respect local governments' constitutional status as a sphere of government, and fails to facilitate meaningful interaction on government priorities across the functions allocated to different spheres" (SALGA 1998: 3). As local government functions have been extended to include "developmental duties" according to section 153 of the Constitution (Ismail and Mphaisha 1997: 16-17), it is indeed questionable whether historical resource flows are sufficient for the local sphere. Comparative evidence may also suggest that local governments, especially in developing countries, require a substantial volume of transfers and grants for effective redistribution to be achieved (Wehner 1998a: 22). However, any increase of the local government share of nationally collected revenues would require equivalent decreases elsewhere. This, in turn, raises the question from where to take additional funds for local government, the national or provincial equitable share.

${ }_{109}$ The FFC used a base share of 51.85 per cent for the 1996-7 financial year, which was derived from budgeted figures presented to Parliament. The 57.6 per cent share used here was calculated on the basis of actual expenditure and revenue data for that year, indicating substantial expenditure overruns.

${ }^{110}$ Although some adjustments where made during this period, which affected this division, they cannot account for the overall trend of declining provincial shares. For instance, the 1998-9 budget introduced a share for local government from the national revenue pool. This share cannot, however, account for the total decrease of provincial transfers: the volume of the local government share represents a mere 0.6 and 0.9 per cent of the national revenue pool in 1998-9 and 1999-0 respectively. Adjustments to provincial allocations for a lower contribution to pension funds (see below) reduced provincial expenditure needs with regard to personnel ( $R 605.5$ million in $1998-9$ or 0.3 per cent of the revenue pool).

111 The department explains that this process took into account the assignment of functions and revenue sources, national priorities, the recommendations and analyses of key sectors by MTEF review teams, an analysis of baseline implications, as well as the delivery implications of altemative levels of funding and policy options. No detailed documentation of this process is available to the public. 
Figure 5: Provincial Allocations from Nationally Collected Revenue (1995-1999)

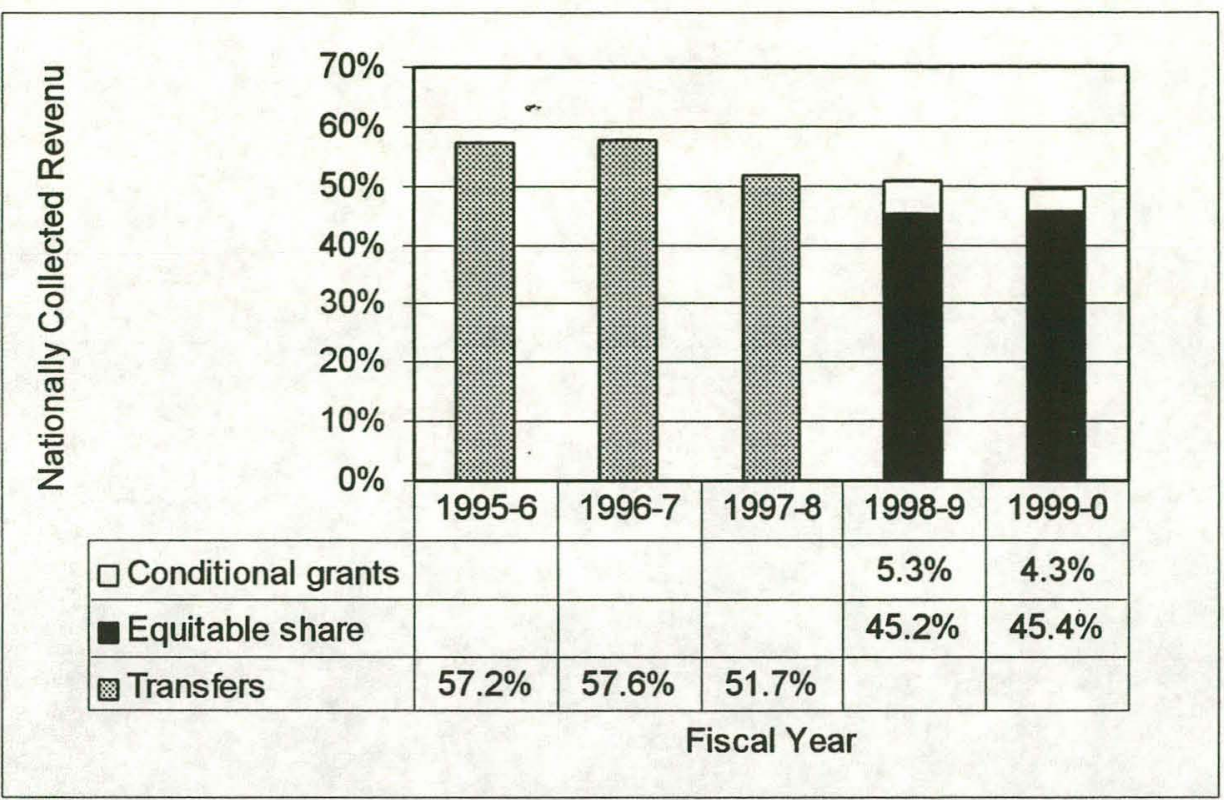

Source: Department of Finance (1999: Annexure B and Table 4.7).

Note: Calculations based on total ordinary national revenue and expenditure data. Total ordinary revenue figures reflect final outcome (1995-6 and 1996-7), preliminary outcome (1997-8), revised estimate (1998-9) and budget estimates after tax proposals (1999-0). Expenditure data represent audited expenditure (1995-6 and 1996-7), preliminary expenditure estimate (1997-8), projected total expenditure after adjustments for the lower 15 per cent employer's contribution to pension funds (1998-9), and budget estimate plus projected improvements in conditions of service (1999-0). Grants to provinces for local government from the Department of Constitutional Development were excluded for the calculation of the share of conditional grants from national departments to provinces.

Table 20: Actual Vertical Division of Resources

\begin{tabular}{|c|c|c|c|c|c|c|c|c|}
\hline & \multicolumn{2}{|c|}{ 1998-9* } & \multicolumn{2}{|c|}{$1999-0$} & \multicolumn{2}{|c|}{$2000-1$} & \multicolumn{2}{|c|}{$2001-2$} \\
\hline & $\begin{array}{l}\mathrm{R} \text { mil- } \\
\text { lion }\end{array}$ & $\begin{array}{l}\% \text { of } \\
\text { total }\end{array}$ & $\begin{array}{l}\mathrm{R} \text { mil- } \\
\text { lion }\end{array}$ & $\begin{array}{l}\% \text { of } \\
\text { total }\end{array}$ & $\begin{array}{l}\mathrm{R} \text { mil- } \\
\text { lion }\end{array}$ & $\begin{array}{l}\% \text { of } \\
\text { total }\end{array}$ & $\begin{array}{l}\mathrm{R} \text { mil- } \\
\text { lion }\end{array}$ & $\begin{array}{l}\% \text { of } \\
\text { total }\end{array}$ \\
\hline Total budget expenditure & 204293 & $100 \%$ & 216780 & $100 \%$ & 230722 & $100 \%$ & 247250 & $100 \%$ \\
\hline \multicolumn{9}{|l|}{ Less 'top-sliced' amounts. } \\
\hline Debt service costs & 43413 & $21.3 \%$ & 48222 & $22.2 \%$ & 49820 & $21.6 \%$ & 52609 & $21.3 \%$ \\
\hline Contingency reserve & - & - & 1100 & $0.5 \%$ & 3500 & $1.5 \%$ & 8000 & $3.2 \%$ \\
\hline Skills development lery grant scheme & $\sigma^{-}$ & - & - & - & 1000 & $0.4 \%$ & 2000 & $0.8 \%$ \\
\hline Donor-financed spending & 651 & $0.3 \%$ & 750 & $0.3 \%$ & 750 & $0.3 \%$ & 750 & $0.3 \%$ \\
\hline Resources to be divided & 160228 & $78.4 \%$ & 166708 & $76.9 \%$ & 175652 & $76.1 \%$ & 183891 & $74.4 \%$ \\
\hline National equitable share & 78273 & $38.3 \%$ & 78733 & $36.3 \%$ & 81100 & $35.2 \%$ & 84489 & $34.2 \%$ \\
\hline \multicolumn{9}{|l|}{ Of which: } \\
\hline National departments & 67573 & $33.1 \%$ & 69972 & $32.3 \%$ & 72739 & $31.5 \%$ & 76232 & $30.8 \%$ \\
\hline $\begin{array}{r}\text { Conditional grants to subnational govern- } \\
\text { ments }\end{array}$ & 10700 & $5.2 \%$ & 8761 & $4.0 \%$ & 8361 & $3.6 \%$ & 8257 & $3.3 \%$ \\
\hline Provincial equitable share & 80931 & $39.6 \%$ & 86302 & $39.8 \%$ & 92071 & $39.9 \%$ & 96822 & $39.2 \%$ \\
\hline Incl. conditional grants & 90499 & $44.3 \%$ & 94420 & $43.6 \%$ & 100432 & $43.5 \%$ & 105079 & $42.5 \%$ \\
\hline Local government equitable share & 1024 & $0.5 \%$ & 1673 & $0.8 \%$ & 2480 & $1.1 \%$ & 2580 & $1.0 \%$ \\
\hline Incl. conditional grants & 2156 & $1.1 \%$ & 2316 & $1.1 \%$ & 2480 & $1.1 \%$ & 2580 & $1.0 \%$ \\
\hline
\end{tabular}

Source: Data from Department of Finance (1999: Table 4.2).

Notes. Equitable shares include estimates of improvements in conditions of service.

* The national and provincial shares of expenditure in 1998-9 are adjusted for the reduction in the employers' contribution to pension funds from 17 per cent to 15 per cent. 
A quantification of the cost of mandates assigned to the different spheres of government may be of value to ascertain the adequacy of the current vertical division. To what extent. such an assessment is feasible remains an issue for further debate.

\subsubsection{Provincial Equitable Share and Conditional Grants}

To split up the provincial pool of revenues among the nine provinces for 1997-8, the Budget Council used a percentage distribution calculated by the FFC (1996: Table 20C). This basic allocation, provincial shares of the "top-sliced" amounts and other adjustments for shifts in functions comprised the total provincial allocation in 1997-8. For the 1998-9 fiscal year the Department of Finance introduced a formula for the horizontal division of revenue.

Table 21: Budgeted Transfers to Provinces for 1996-7 and 1997-8

$R$ million unless otherwise indicated

\begin{tabular}{lcccccccc}
\multicolumn{2}{c}{$1996-7$} & \multicolumn{7}{c}{$1997-8$} \\
\hline & Budget & $\%$ of total & $\begin{array}{c}\text { Basic share } \\
\text { of revenue }\end{array}$ & $\begin{array}{c}\text { Function } \\
\text { shifts }\end{array}$ & $\begin{array}{c}\text { Carry } \\
\text { through costs }\end{array}$ & $\begin{array}{c}\text { Increases in } \\
\text { social grants }\end{array}$ & Budget & $\%$ of total \\
\hline EC & 14001 & $18.5 \%$ & 12173 & 17 & 1389 & 191 & 13770 & $17.0 \%$ \\
FS & 5196 & $6.9 \%$ & 4767 & 71 & 650 & 57 & 5545 & $6.9 \%$ \\
G & 11108 & $14.7 \%$ & 10959 & 141 & 1700 & 111 & 12911 & $16.0 \%$ \\
KZN & 14664 & $19.4 \%$ & 13560 & 7 & 1711 & 214 & 15492 & $19.2 \%$ \\
M & 4610 & $6.1 \%$ & 4192 & 113 & 449 & 48 & 4802 & $5.9 \%$ \\
NC & 1769 & $2.3 \%$ & 1529 & 219 & 194 & 32 & 1974 & $2.4 \%$ \\
NP & 9324 & $12.3 \%$ & 8669 & 6 & 1598 & 96 & 10369 & $12.8 \%$ \\
NW & 6450 & $8.5 \%$ & 5956 & 145 & 615 & 68 & 6784 & $8.4 \%$ \\
WC & 8378 & $11.1 \%$ & 7375 & 92 & 1170 & 120 & 8757 & $10.8 \%$ \\
Supple- & - & - & - & - & - & - & 402 & $0.5 \%$ \\
mentary & & & & & & & & \\
Total & 75499 & $100.0 \%$ & 69180 & 811 & 9476 & 937 & 80806 & $100.0 \%$ \\
\hline
\end{tabular}

Soure. Department of Finance (1997a: 6.5).

Table 22: Provincial Population Shares

\begin{tabular}{|c|c|c|c|c|c|c|}
\hline & \multicolumn{2}{|c|}{$\begin{array}{l}\text { Demographic Infor- } \\
\text { mation Bureau data } \\
\text { (used in 1997-8) }\end{array}$} & \multicolumn{2}{|c|}{$\begin{array}{c}\text { Preliminary } 1996 \text { Cen- } \\
\text { sus results (used in } \\
1998-9 \text { ) }\end{array}$} & \multicolumn{2}{|c|}{$\begin{array}{l}\text { Final } 1996 \text { Census re- } \\
\text { sults (used for } 1999-0 \\
\text { and beyond) }\end{array}$} \\
\hline & Thousands & $\%$ of total & Thousands & $\%$ of total & Thousands & $\%$ of total \\
\hline Eastem Cape & 7454 & $16.2 \%$ & 5865 & $15.5 \%$ & 6303 & $15.5 \%$ \\
\hline Free State & 3098 & $6.7 \%$ & 2470 & $6.5 \%$ & 2634 & $6.5 \%$ \\
\hline Gauteng & 8580 & $18.7 \%$ & 7171 & $18.9 \%$ & 7348 & $18.1 \%$ \\
\hline KwaZulu-Natal & 9453 & $20.6 \%$ & 7672 & $20.3 \%$ & 8417 & $20.7 \%$ \\
\hline Mpumalanga & 3019 & $6.6 \%$ & 2646 & $7.0 \%$ & 2801 & $6.9 \%$ \\
\hline Northem Cape & 807 & $1.8 \%$ & 746 & $2.0 \%$ & 840 & $2.1 \%$ \\
\hline Northem Province & 5652 & $12.3 \%$ & 4128 & $10.9 \%$ & 4929 & $12.1 \%$ \\
\hline North West & 3907 & $8.5 \%$ & 3043 & $8.0 \%$ & 3355 & $8.3 \%$ \\
\hline Westem Cape & 3987 & $8.7 \%$ & 4118 & $10.9 \%$ & 3957 & $9.7 \%$ \\
\hline Total & 45957 & $100 \%$ & 37859 & $100 \%$ & 40584 & $100 \%$ \\
\hline
\end{tabular}

Sources. Financial and Fiscal Commission (1996: Table 7.2) and Department of Finance (1999: Table 4.5). 
Table 23: Actual Formula for the Distribution of the Provincial Equitable Share Component share per province in per cent

\begin{tabular}{|c|c|c|c|c|c|c|c|c|c|c|c|c|c|c|c|c|}
\hline \multirow{2}{*}{ Year } & \multicolumn{2}{|c|}{ Education } & \multicolumn{2}{|c|}{ Health } & \multicolumn{2}{|c|}{ Welfare } & \multicolumn{2}{|c|}{$\begin{array}{l}\text { Basic } \\
\text { share }\end{array}$} & \multicolumn{2}{|c|}{$\begin{array}{c}\text { Economic } \\
\text { activity }\end{array}$} & \multicolumn{2}{|c|}{$\begin{array}{c}\text { Institu- } \\
\text { tional }\end{array}$} & \multicolumn{2}{|c|}{ Backlogs } & \multicolumn{2}{|c|}{$\begin{array}{l}\text { Target } \\
\text { shares }\end{array}$} \\
\hline & 80 & 999 & 1998 & & 1998 & & 1998 & 1999 & 1998 & 1999 & 1998 & 1999 & 200 & & 1998 & 199 \\
\hline Weight & 39.0 & 0.0 & 18.0 & 8.0 & 16.0 & 17.0 & 5.0 & 9.0 & 8. & 8.0 & 4.0 & 5. & & 3.0 & 100.0 & 100.0 \\
\hline 7 & 18.5 & 5 & 17.3 & 0 & 18.7 & 1 & 6.6 & 15.5 & 7. & 9 & 1.1 & 11 & & .7 & 16.9 & 16 \\
\hline & 6 & & 6.7 & & 6.6 & & & 6.5 & 6 & 5.1 & 1.1 & 11 & & & .0 & 6.6 \\
\hline & 3. & & 15.6 & & 3.3 & & 5.8 & 18.1 & .7 & & 1.1 & & & & 6.2 & 157 \\
\hline & 1.3 & 1 & 21.1 & & 21.0 & 1 & 21.2 & 20.7 & 14.9 & 18.9 & 11.1 & 11 & & 23.0 & 20.3 & 20.7 \\
\hline & & & 7.0 & 7 & 7.2 & & 7.5 & 6 & 8.1 & 7 & 11.1 & 11. & & .5 & 7.6 & 7.1 \\
\hline & & & 2.0 & & 2.0 & & 1.8 & 2.1 & 2 & & 11.1 & 1 & & 1.0 & 2.3 & 2.4 \\
\hline & 4.3 & 15.7 & 11.8 & 3 & 13.2 & & 12.8 & 12.1 & 3 & 1.7 & 11.1 & 11 & & 22.9 & 12.5 & 13.5 \\
\hline JW & & & 83 & 8. & 8 & & 8 & 8.3 & 5.6 & & 11.1 & 11 & & 9.5 & 8.2 & 8.2 \\
\hline VC & 3.5 & 7.9 & 10.3 & 8.9 & 9.1 & 8.8 & 9.3 & 9.7 & 14.1 & 13.7 & 11.1 & 11.1 & - & 3.6 & 9.6 & 8.9 \\
\hline otal & 00. & 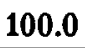 & 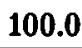 & 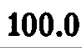 & 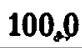 & O & 0 & 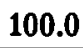 & 100 & 100.0 & 100. & 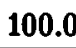 & - & an & 100 & 100 \\
\hline
\end{tabular}

Source. Department of Finance (1998b: E23 and 1999: 263).

Note. Totals may not add due to rounding.

For 1999-0 the weightings of the different component were adjusted "to reflect actual expenditure trends in the provinces" (Department of Finance 1999: 101). ${ }^{112}$ The incorporation of the final 1996 Census figures in 1999-0 also impacted on provincial allocations, given the formula's sensitivity to demographic factors (Donian and Rip-Botha 1997). The final population figures show a different distribution than the preliminary estimates, which were used to calculate equitable share allocations in the 1998 budget. ${ }^{113}$ Provinces such as the Northern Province and KwaZulu-Natal gained from the revised census data. The most notable loser of the adjusted census figures, compared with the preliminary results, is the Western Cape. It is the only province whose population figure was decreased in the adjustment process, and its target share has been subject to the biggest decrease compared with the other provinces. ${ }^{114}$

To enable provinces to adjust to increases or decreases as a result of the new process, the formula will be phased in over a period of five years. Based on the final equitable share allocations for 1998-9, provincial allocations will be subject to five equal moves towards

\footnotetext{
112 The weightings attached to the education, welfare and institutional components were increased. The previous basic component was split into a basic share and a backlog component. The combined weighting of these components was reduced from 15 to 12 per cent to accommodate increases elsewhere. These changes are discussed in detail below.

${ }^{113}$ However, the available documentation does not isolate the impact of the final census data from that of the formula changes. The impact of the new data alone would be made explicit by the distribution outcome of the new formula, but calculated with the population data used in the previous year. The difference between this calculation and the current share for each province would equal the effect of data changes. 114 The provincial government of the Westem Cape has questioned the credibility of the adjusted figures (Business Day, 22 October 1998). It commissioned a report from independent consultants, which disputed the census data (Business Day, 10 December 1998).
} 
the target share. The further development of the formula has to be carefully balanced with the benefits of a predictable revenue allocation process. Walker (1999: 7) comments: "Continual changes introduce instability and uncertainty into the system, making it more difficult for provinces to plan their expenditures and manage adjustments required."

The formula is currently made up of seven components, which are not intended to indicate how provinces should allocate their resources. Rather, they represent estimates of the distribution of demands for services (Department of Finance 1999: 262-268):

The education component targets primary and secondary schooling, which accounts for roughly 90 per cent of provincial education spending. Both the school-age population and the numbers of pupils enrolled are relevant to funding needs. The distribution of children of school-going age does not reflect repeater rates and the numbers of under or over-age pupils in the system. But using the number of enrolled pupils only would create perverse incentives. ${ }^{115}$ For $1998-9$ a simple average of the two was used. From 1999-0 the education component double weights the school-age cohort, as an incentive for provinces to reduce the number of over and under-age learners.

The health component addresses the need for provinces to deliver primary and secondary health services. As all citizens are eligible for health services, the provincial shares of the total population form the basis for the health share. A distinction is made between those with access to medical insurance and those without. Contrary to 1998-9, people with private medical insurance were not removed from the base population in 1999-0, to reflect that they are eligible to use public health facilities should they choose so. However, people without medical aid are weighted four times higher, assuming that the uninsured account for 95 per cent of public health facilities usage. ${ }^{116}$

The welfare component captures the responsibility of provinces to provide social security grants. The target populations of social security payments are weighted by the historical distribution of each type of grant. The base populations for the old age and childcare sub-components are those proportions of the population that are eligible for grants: males over age sixty-five, females over sixty and children under six. The base population

115 Such a funding system would provide no incentive for provincial departments to improve passing rates, but reward poor performance by not penalising high repeater rates. 
for the disability sub-component is the total population, based on an assumed symmetrical distribution of the disabled across the provinces. An income factor is incorporated to capture the impact of the means test for old age and child support grants, considering the provincial share of the population that falls in the lowest two quintiles of the income distribution. The final welfare share is a combination of the income factor, weighted twenty-five per cent, and the weighted average of grant populations.

The basic component was in 1998-9 weighted in favour of the rural population as a proxy for poverty. The newly introduced backlog component now incorporates the rural weighting, while the basic component is distributed by percentage share of the total population.

The economic activity component, in the absence of effective provincial taxation powers, acts as a proxy for provincial tax revenue. It directs a proportion of nationally collected revenues back to source. It also reflects the costs associated with economic activity, such as the maintenance of provincial roads. ${ }^{117}$

The institutional component is targeted at covering the costs associated with running a basic structure for government. It is evenly distributed between provinces in an attempt to take into account certain fixed costs that all provinces must incur, irrespective of their size or state of development.

The backlog component was introduced in 1999-0 to address criticisms that the formula had failed to take into account the developmental backlogs in some provinces. Its three subcomponents recognise the need for capital spending on rural infrastructure and facilities in the health and education sectors. The health and education sub-components are weighted as in the main formula, according to aggregate provincial spending on these functions, 18 and 40 per cent respectively. The health and education distributions are based on the distribution of capital needs identified in the audit of hospital facilities and schools register of needs. Provincial shares of the rural population inform the distribution of the remaining 42 per cent.

\footnotetext{
116 The proportions of the population with and without access to medical aid were taken from the 1995 October Household Survey and applied to the census figures.

117 Gross Geographical Product (GGP) figures for 1994 were used in 1998-9 to estimate the distribution of economic activity across the provinces. Because updated GGP figures are unavailable, they were replaced in 1999-0 by the distribution of remuneration of employees. Remuneration data are the largest component of provincial GGP.
} 
Two personnel related deductions from the provincial equitable shares, as calculated by the formula explained above, were made in 1999-0. The estimated distribution of improvements in conditions of service was removed from the equitable share, to be allocated as a conditional grant once wage negotiations have been concluded. Second, the employers' contribution to the Government Employees Pension Fund was reduced from 17 per cent to 15 per cent. The adjustment was distributed to reflect lower expenditure commitments rather than a reduction in services. ${ }^{118}$

In addition to the equitable share, which is unconditional, a number of conditional grants were introduced with the 1998 budget, which are channelled through various national departments (Department of Finance 1999: 103-106). The largest conditional grants are found on the vote of the national Department of Health and relate mainly to specialised health services that are not provided by all the provinces (Van den Heever 1998). The conditional grant for education seeks to improve the quality of education and support various initiatives. The conditional grant from the Department of Finance was introduced in response to financial difficulties in certain provinces in 1997-8. Provinces also receive conditional grants for local government (see following section). In 1999-0, conditional grants comprise about 10 per cent of the total volume of transfers and grants to provinces, with the equitable share making up the remainder.

\footnotetext{
118 In 1998-9 the savings of lower pension fund contributions were deducted from total expenditure, rather than allocated to provincial and national departments.
} 
Table 24: Conditional Grants to Provinces* $\mathrm{R}$ millions

\begin{tabular}{|c|c|c|c|c|}
\hline$\cdots$ & $1998-9^{* *}$ & $1999-0$ & $2000-1$ & $2001-2$ \\
\hline \multicolumn{5}{|l|}{ Health } \\
\hline Central hospitals & 3021 & 3075 & 3112 & 3221 \\
\hline Training and research & 1060 & 1118 & 1174 & 1215 \\
\hline Redistribution of specialised services & 53 & 112 & 176 & 182 \\
\hline Hospital rehabilitation programme & - & 200 & 400 & 500 \\
\hline Durban Academic Hospital & 200 & 247 & 273 & 103 \\
\hline Umtata Regional Hospital & 100 & 64 & - & - \\
\hline Primary school nutrition programme & 526 & 555 & 582 & 603 \\
\hline \multicolumn{5}{|l|}{ Finance } \\
\hline Supplementary grant & 2800 & 2500 & 2212 & 2000 \\
\hline \multicolumn{5}{|l|}{ Education } \\
\hline Financial management and quality enhancement & 200 & 111 & 272 & 283 \\
\hline Classroom backlogs & 50 & - & - & - \\
\hline KwaZulu-Natal peace initiative & 81 & - & - & - \\
\hline \multicolumn{5}{|l|}{ Housing } \\
\hline $\begin{array}{l}\text { Capacity building } \\
\text { State Expenditure }\end{array}$ & 10 & 10 & 10 & 10 \\
\hline \multicolumn{5}{|l|}{ Welfare } \\
\hline \multicolumn{5}{|l|}{ Labour } \\
\hline Training centres in former Bophuthatswana & 52 & 56 & - & - \\
\hline Other conditional grants & 15 & - & - & - \\
\hline Sub-total & 9568 & 8118 & 8361 & 8257 \\
\hline \multicolumn{5}{|l|}{$\begin{array}{l}\text { Department of Constitutional Development } \\
\text { Grants to provinces for local government }\end{array}$} \\
\hline R293 staff & 951 & 463 & - & - \\
\hline R293 transfer cost assistance grant & - & 40 & - & - \\
\hline Local govemment support grant ${ }^{* * * *}$ & 181 & 140 & - & - \\
\hline Sub-total & 1132 & 643 & - & - \\
\hline Total & 10700 & 8761 & 8361 & 8257 \\
\hline
\end{tabular}

Source: Department of Finance (1999: Table 4.7).

Notes.

* Improvements in condition of service are appropriated as a conditional grant in 1998-9 and 1999-0 but will become part of the equitable share in 2000-1. The amounts to provinces for 1998-9 and 1999-0 are $R$ 2419 million and $R 2100$ respectively.

** Some conditional grants had not yet been allocated to provinces.

*** This grant was called the local govemment transition grant in 1998-9.

\subsubsection{Local Government Equitable Share and Conditional Grants}

The formula used by the Department of Finance for the distribution of the local government share differs from that recommended by the FFC. Most notably, it consists of only two components (Department of Finance 1998b and 1999: 113-115):

A municipal basic services transfer aims to enable poor residents in all local government jurisdictions to access basic municipal services. The basic approach involves estimating the 
number of people in poverty (household income less than R 800 per month in 1998 prices) and the current annual cost of providing basic services for each person.

A municipal institutions transfer is earmarked for those jurisdictions currently lacking the administrative capacity to raise their own revenue or lacking the basic infrastructure necessary to function as local authorities. This transfer pays for a minimum level of resources to provide and maintain basic facilities for the operation of local government (such as a community centre and an office for elected officials).

A number of historically privileged municipalities will receive lower subsidies in the future. A once-off transitional grant of R 181 million was introduced in 1998-9 to assist in this adjustment. For the 1999-0 fiscal year, the equitable share also includes R 447 million, which will be given directly to former so-called R293 towns ${ }^{119}$ for functions that were previously paid for by provinces. It is expected that these funds will be fully incorporated into the local government equitable share from 2000-1.

In addition to the local government equitable share, local governments also receive conditional grants and agency payments from national and provincial governments for both capital and recurrent expenditure. Grants for recurrent expenditure cover R293 staff and assist in the transfer process and in rationalising local administrations. The main capital transfer to local government is the Consolidated Municipal Infrastructure Programme. This is a medium to long-term capital grant programme administered by the Department of Constitutional Development. Municipalities are requested to forward business plans to the department for the funds to be released.

\subsubsection{Review of Recommendations and Practices}

Current practice diverts substantially in some important aspects from the original recommendations made by the FFC. Most notably, there has been a decrease in the provincial share of nationally collected revenues instead of the increase recommended by the

\footnotetext{
119 R293 towns are largely local authorities which were operated by the former homeland authorities. Allocations for services and staff in R293 towns have been channelled through the provinces in previous years, but it was planned to incorporate these funds into the equitable share during 1999-0. This was dependent on the progress with transferring staff from the provinces to these local authorities. Due to this process being slower than expected, service subsidies in 1999-0 are going directly to these towns through the equitable share, while a conditional grant covers staff costs until provinces are able to transfer the staff.
} 
FFC. The Department of Finance describes the vertical division as a "political judgement made by Cabinet". This description stands in stark contrast to the process and roleplayers outlined in the Constitution, which awards a substantial role to the FFC and requires the consultation of provincial governments and organised local government.

The FFC has argued for the implementation of provincial taxation powers, in conjunction with an equalisation component in the formula, to introduce accountability on the revenue side. The Department of Finance has been reluctant to follow this approach.

Several adjustments were made to the provincial formula for the 1999-0 financial year to accommodate a backlog component. However, in the light of decreasing budgets in real terms and dwindling capital expenditures, it is doubtful that provinces "should be able to include amounts in their budgets to address these backlogs over the medium term" (Department of Finance 1999: 101). The FFC has argued that backlogs should rather be addressed through ad hoc grants from the national government (FFC 1996: 3). In addition, as noted in chapter 2 (see section on borrowing arrangements), effective borrowing powers for provinces are likely to be required to finance developmental expenditure. ${ }^{120}$

The formula used by the Department of Finance for the horizontal distribution of the local government share also excludes the tax capacity (equalisation) component suggested by the commission, which would be an incentive to improve revenue collection.

The local government formula also excludes the capital grant suggested by the FFC. Whereas the FFC proposed an automatic grant system, the current arrangement under the auspices of the Department of Constitutional Development is application-driven.

The FFC is presently working on "Project 2001". The objectives of the project are "to test the original and subsequent recommendation of the FFC against current practice and to prepare comprehensive recommendations for 2001-2 and subsequent fiscal years" (FFC 1999: 1). Such a review will be a valuable resource, as definitional inconsistencies

${ }^{120}$ The backlog component is also the smallest component of the formula, accounting for the distribution of merely 3 per cent of the provincial equitable share. The basic component was previously weighted in favour of the rural population as a proxy for poverty. With the introduction of the backlog component, the rural weighting was removed, and the basic share is being distributed according to provincial percentage shares of the total population. Therefore, the redistributing effect of the basic component was weakened, which to some extent neutralised the actual impact of the backlog component. The backlog component has accordingly been described as "notional" (Interview: Donian, 8 April 1999). 
and a range of continuous adjustments currently obscure a definite quantitative assessment of the discrepancies outlined above. The prevailing perception inside the FFC is that the commission has been sidelined, most likely because its recommendations are regarded as too much in favour of decentralisation (Interview: Donian, 8 April 1999). The commission hopes to improve its impact by working more closely with Parliament through a liaison office to be established in Cape Town. Otherwise, the demoralisation and exodus of qualified staff may well leave the commission as a constitutional ruin. In a system where revenues are almost totally centralised, the sidelining of the FFC is a threat to the impartiality of the revenue-sharing process.

\subsection{Borrowing Arrangements}

While the Constitution does not limit the borrowing activities of the national sphere, it prescribes that provincial and local governments may raise loans for capital or current expenditure in accordance with reasonable conditions determined by national legislation (section 230). Loans for current expenditure may only be raised for bridging purposes during a fiscal year, and must be repaid within twelve months. ${ }^{121}$

\subsubsection{Provincial Borrowing}

The Borrowing Powers of Provincial Governments Act (1996) allows for the Budget Council to function as a Loan Co-ordinating Committee (LCC). The act requires the committee to co-ordinate the annual borrowing requirements of the provinces, considering the aggregate demand for capital market funds. The LCC would consider overall debt levels in the provinces, their contingent liabilities and ability to service their debt. The committee is required to report to the FFC on these matters. However, these provisions have never been fully functional since, at a Budget Council meeting on 5 January 1997, the majority of provinces agreed not to borrow. The first requests were submitted to the LCC only towards the end of the 1998-9 fiscal year (Interview: Donian, 8 April 1999).

121 These restrictions must be seen against the experience with borrowing in the former homelands. Commitments of $\mathrm{R} 14,8$ billion due to the indebtedness of the former TBVC states and self-governing ternitories had to be converted to national debe after the dismantling of apartheid (Department of Finance 1999: 78). 
Most provinces have instead resorted to drawing down deposits and utilising overdraft facilities with banks to finance unanticipated expenditure needs. The provinces' combined bank overdrafts stood at R 2.8 and 1.6 billion in December 1997 and 1998 respectively (Business Day, 15 February 1999). Other means of implicit borrowing include rolling over debtors' accounts, withholding payments to the receiver, withholding employer contributions from the pension fand and withholding pay progression for public servants despite wage agreements (Fölscher 1999: 2). ${ }^{122}$

The Public Finance Management Act (1999) further prohibits provinces from entering commitments in foreign currency (section 67). This follows a scandal revolving around secret funding deals with state assets by the Mpumalanga Parks Board, which issued six illegal promissory notes valued at about R 1.3 billion without cabinet or Reserve Bank approval. The promissory notes used the assets of the board as collateral for international loans (Business Day, 25 September 1998). The Department of Finance is currently working towards a new and consolidated framework for provincial borrowing (Fölscher 1999).

\subsubsection{Local Borrowing}

Separate legislation pertaining to local financial management is expected in the near future. A general constraint on local borrowing is the fact that a mere 150 out of $843 \mathrm{mu}$ nicipalities in the country are estimated to be credit-worthy. The largest of these can be found in the well-developed urban areas (Business Day, 14 September 1998). Adjustments to the existing municipal boundaries and amalgamations may facilitate a more even access to the borrowing market. However, it is also possible that the ratings of municipalities with high credit-ratings could drop if they were to merge with other local authorities burdened by debt. These ratings could rise again as a result of savings due to economies of scale and the elimination of duplication (Business Day, 5 June 1998).

122 For example, after signing the 1996 wage agreement at national level, the Eastem Cape government failed to put the relevant personnel onto the new salary system which would have ensured various promotions, affecting about 60 per cent of public servants in the province (Business Day, 11 May 1999). 


\subsection{Chapter Conclusion}

This chapter provided an in-depth analysis of intergovernmental fiscal relations in South Africa. The Constitution sets out a pattem that gives the national Parliament broad legislative powers, while relying heavily on the provinces for the implementation of national policy, especially with regard to the social expenditure areas. Provinces currently do not have effective taxation powers, and rely almost totally on transfers and grants from the national pool of revenue. The degree of provincial fiscal dependency requires a wellbalanced and sizeable system of transfers and grants to address both vertical as well as horizontal imbalances. The design of such a system has been one of the foremost challenges that came with the new constitutional order. Local governments, on the other hand, have been expected to cover the overwhelming share of expenditure with own revenues. However, varied collection abilities and revenue bases make for a substantial asymmetry within the local sphere. Subnational Expenditure and Revenue data is summarised in the following tables. 
Table 25: Consolidated Provincial Revenue and Expenditure

$R$ billion

\begin{tabular}{|c|c|c|c|c|c|c|c|}
\hline & \multicolumn{3}{|c|}{ Actual } & \multirow{2}{*}{$\begin{array}{c}\text { Preliminary } \\
\text { estimate } \\
1998-9 \\
\end{array}$} & \multicolumn{3}{|c|}{ Medium term estimates } \\
\hline & 1995-6 & $1996-7$ & $1997-8$ & & $1999-0$ & $2000-1$ & $2001-2$ \\
\hline Transfers* & 72.9 & 84.7 & 86 & 91.7 & 94.3 & 99.4 & 104 \\
\hline Own revenue & 4.3 & 4.2 & 3.5 & 3.3 & 3.7 & 4 & 4.2 \\
\hline Total revenue & 772 & 88.9 & 89.4 & 95 & 98.1 & 103.5 & 108.2 \\
\hline per cent increase & - & $15.1 \%$ & $0.6 \%$ & $6.2 \%$ & $3.3 \%$ & $5.5 \%$ & $4.6 \%$ \\
\hline Education & 29.4 & 36.6 & 38.7 & 38.8 & 40.3 & 42.6 & 44.7 \\
\hline Health & 15.8 & 20.4 & 22.4 & 22.7 & 23.7 & 25.3 & 26.3 \\
\hline Welfare & 14.4 & 15.9 & 17.7 & 18.4 & 18.7 & 19.5 & 20.3 \\
\hline Other & 16.2 & 18.5 & 16.6 & 14.5 & 13.5 & 13.9 & 14.6 \\
\hline Finance reserve & & & & & 1.9 & 2.1 & 2.3 \\
\hline Total expenditure & 75.9 & 91.4 & 95.3 & 94.4 & 98.1 & 103.5 & 108.2 \\
\hline per cent increase & - & $20.4 \%$ & $4.3 \%$ & $-1.0 \%$ & $3.9 \%$ & $5.5 \%$ & $4.6 \%$ \\
\hline Personnel spending & 40.3 & 49.2 & 54.5 & 55.9 & 58.3 & 61.2 & 63.9 \\
\hline Surplus / deficit & 1.3 & -2.5 & -5.9 & 0.6 & - & - & - \\
\hline per cent of $G D P$ & $0.3 \%$ & $-0.5 \%$ & $-1.0 \%$ & $0.1 \%$ & - & - & - \\
\hline
\end{tabular}

Source. Department of Finance (1999: Table 4.1).

Notes: Totals may not add due to rounding.

* From nationally collected revenue, excluding conditional grants.

Table 26: Composition of Consolidated Provincial Revenue and Expenditure

Per cent of total

\begin{tabular}{|c|c|c|c|c|c|c|c|}
\hline & \multicolumn{3}{|c|}{ Actual } & \multirow{2}{*}{$\begin{array}{c}\begin{array}{c}\text { Preliminary } \\
\text { estimate }\end{array} \\
1998-9\end{array}$} & \multicolumn{3}{|c|}{ Medium term estimates } \\
\hline & $1995-6$ & $1996-7$ & $1997-8$ & & $1999-0$ & $2000-1$ & $2001-2$ \\
\hline Transfers* & $94.4 \%$ & $95.3 \%$ & $96.2 \%$ & $96.5 \%$ & $96.1 \%$ & $96.0 \%$ & $96.1 \%$ \\
\hline Own revenue & $5.6 \%$ & $4.7 \%$ & $3.9 \%$ & $3.5 \%$ & $3.8 \%$ & $3.9 \%$ & $3.9 \%$ \\
\hline Total revenue & $100.0 \%$ & $100.0 \%$ & $100.0 \%$ & $100.0 \%$ & $100.0 \%$ & $100.0 \%$ & $100.0 \%$ \\
\hline Education & $38.7 \%$ & $40.0 \%$ & $40.6 \%$ & $41.1 \%$ & $41.1 \%$ & $41.2 \%$ & $41.3 \%$ \\
\hline Health & $20.8 \%$ & $22.3 \%$ & $23.5 \%$ & $24.0 \%$ & $24.2 \%$ & $24.4 \%$ & $24.3 \%$ \\
\hline Welfare & $19.0 \%$ & $17.4 \%$ & $18.6 \%$ & $19.5 \%$ & $19.1 \%$ & $18.8 \%$ & $18.8 \%$ \\
\hline Other & $21.3 \%$ & $20.2 \%$ & $17.4 \%$ & $15.4 \%$ & $13.8 \%$ & $13.4 \%$ & $13.5 \%$ \\
\hline Finance reserve & - & - & - & - & $1.9 \%$ & $2.0 \%$ & $2.1 \%$ \\
\hline Total expenditure & $100.0 \%$ & $100.0 \%$ & $100.0 \%$ & $100.0 \%$ & $100.0 \%$ & $100.0 \%$ & $100.0 \%$ \\
\hline Personnel spending & $53.1 \%$ & $53.8 \%$ & $57.2 \%$ & $59.2 \%$ & $59.4 \%$ & $59.1 \%$ & $59.1 \%$ \\
\hline
\end{tabular}

Source. Own calculations based on data in Department of Finance (1999: Table 4.1).

Notes: Totals may not add due to rounding.

* From nationally collected revenue, excluding conditional grants. 
Table 27: Local Government Revenue and Expenditure

$\mathrm{R}$ million

\begin{tabular}{|c|c|c|c|c|c|c|c|}
\hline & \multirow{2}{*}{\multicolumn{3}{|c|}{ Estimated }} & \multirow{2}{*}{\multicolumn{4}{|c|}{ Projected }} \\
\hline & & & & & & & \\
\hline & 1995-6 & 1996-7 & $1997-8$ & 1998-9 & $1999-0$ & $2000-1$ & $2001-2$ \\
\hline Tax revenue & 6701 & 7508 & 8264 & 9142 & 9707 & 11054 & 11924 \\
\hline Non-tax revenue & 9385 & 10136 & 9394 & 9954 & 10891 & 12092 & 12961 \\
\hline Capital revenue & 625 & 384 & $\cdot 434$ & 450 & 499 & 539 & 583 \\
\hline Total grants & 4089 & 6067 & 6350 & 5324 & 6077 & 6377 & 6931 \\
\hline of which equitable share & - & - & - & 1024 & 1673 & 2480 & 2580 \\
\hline Revenue & 20800 & 24095 & 24442 & 24870 & 27174 & $29062 *$ & 32399 \\
\hline \multicolumn{8}{|l|}{ Current } \\
\hline Goods and services & 14124 & 17502 & 17563 & 16885 & 17982 & 18763 & 20538 \\
\hline Interest & 1704 & 1030 & 1245 & 1382 & 1477 & 1598 & 1728 \\
\hline \multicolumn{8}{|l|}{ Capital } \\
\hline Acquisition of fixed assets & 4105 & 4547 & 4742 & 5197 & 5934 & 6467 & 7043 \\
\hline Capital transfers & 492 & 498 & 454 & 778 & 900 & 1000 & 1150 \\
\hline Net lending & 590 & 649 & 714 & 694 & 795 & 860 & 930 \\
\hline Expenditure & 21329 & 24862 & 25233 & 25376 & 27488 & 29088 & 31839 \\
\hline Surplus / deficit & -529 & -767 & -791 & -506 & -314 & -26 & 560 \\
\hline
\end{tabular}

Source. Department of Finance (1999: Table 4.10).

Notes: The estimates reflect South African Reserve Bank data, based on a sample survey by Statistics South Africa covering 60 local authorities. The Department of Finance prepared the projections beginning with 1998-9.

* Total reflects inconsistencies in the Department of Finance data.

Table 28: Composition of Local Govermment Revenue and Expenditure

Per cent of total

\begin{tabular}{|c|c|c|c|c|c|c|c|}
\hline & \multirow{2}{*}{\multicolumn{3}{|c|}{ Estimated }} & \multirow{2}{*}{\multicolumn{4}{|c|}{ Projected }} \\
\hline & & & & & & & \\
\hline & 1995-6 & 1996-7 & $1997-8$ & $1998-9$ & 1999-0 & $2000-1$ & $2001-2$ \\
\hline Tax revenue & $32.2 \%$ & $31.2 \%$ & $33.8 \%$ & $36.8 \%$ & $35.7 \%$ & $38.0 \%$ & $36.8 \%$ \\
\hline Non-tax revenue & $45.1 \%$ & $42.1 \%$ & $38.4 \%$ & $40.0 \%$ & $40.1 \%$ & $41.6 \%$ & $40.0 \%$ \\
\hline Capital revenue & $3.0 \%$ & $1.6 \%$ & $1.8 \%$ & $1.8 \%$ & $1.8 \%$ & $1.9 \%$ & $1.8 \%$ \\
\hline Total grants & $19.7 \%$ & $25.2 \%$ & $26.0 \%$ & $21.4 \%$ & $22.4 \%$ & $21.9 \%$ & $21.4 \%$ \\
\hline of which equitable share & - & - & - & $4.1 \%$ & $6.2 \%$ & $8.5 \%$ & $8.0 \%$ \\
\hline Revenue & $100.0 \%$ & $100.0 \%$ & $100.0 \%$ & $100.0 \%$ & $100.0 \%$ & $103.4 \% *$ & $100.0 \%$ \\
\hline Current & & & & & & & \\
\hline Goods and services & $66.2 \%$ & $70.4 \%$ & $69.6 \%$ & $66.5 \%$ & $65.4 \%$ & $64.5 \%$ & $64.5 \%$ \\
\hline Interest & $8.0 \%$ & $4.1 \%$ & $4.9 \%$ & $5.4 \%$ & $5.4 \%$ & $5.5 \%$ & $5.4 \%$ \\
\hline $\begin{array}{c}\text { Subsidies and transfers } \\
\text { Capital }\end{array}$ & $1.5 \%$ & $2.6 \%$ & $2.0 \%$ & $1.7 \%$ & $1.5 \%$ & $1.4 \%$ & $1.4 \%$ \\
\hline Acquisition of fixed assets & $19.2 \%$ & $18.3 \%$ & $18.8 \%$ & $20.5 \%$ & $21.6 \%$ & $22.2 \%$ & $22.1 \%$ \\
\hline Capital transfers & $2.3 \%$ & $2.0 \%$ & $1.8 \%$ & $3.1 \%$ & $3.3 \%$ & $3.4 \%$ & $3.6 \%$ \\
\hline Net lending & $2.8 \%$ & $2.6 \%$ & $2.8 \%$ & $2.7 \%$ & $2.9 \%$ & $3.0 \%$ & $2.9 \%$ \\
\hline Expenditure & $100.0 \%$ & $100.0 \%$ & $100.0 \%$ & $100.0 \%$ & $100.0 \%$ & $100.0 \%$ & $100.0 \%$ \\
\hline
\end{tabular}

Source. Own calculations based on data in Department of Finance (1999: Table 4.10).

Notes. Estimates based on Reserve Bank figures, projections by the Department of Finance.

* Total reflects inconsistencies in the Department of Finance data. 


\section{CHAPTER 5: CONCLUSION}

This thesis set out to capture the assignment of functions and resources to the different spheres of government in South Africa and to provide an assessment of the functionality of this assignment. The purposes of this chapter are to summarise the main findings and to come to an assessment of the functionality of the South African system. Based on this assessment, the necessity of adjusting the current assignment of functions and resources for the sake of greater efficiency will be investigated.

The second chapter reviewed considerations in the design of fiscal federalism. The discussion generated economic reference frameworks for the assignment of expenditure responsibilities, sources of revenue, and the design of a system of intergovernmental transfers and grants. The analysis also indicated that constitutions can impose limits on fiscal design. The implication is that any policy recommendations concerning the assignment of functions and revenues cannot ignore an existing constitutional framework.

The third chapter demonstrated the impact of constitutional models for regional government on fiscal arrangements in a country. In the divided model (as in Canada), national and regional governments pursue their functions as independently as possible and directly access sources of revenue. In the shared model (as in Germany), the emphasis is on concurrent responsibility and shared sources of revenue. An issue for further research is whether, in general, divided models are associated with a higher degree of (expenditure and revenue) decentralisation than shared models.

The fourth chapter provided an in-depth analysis of the South African system. It shows that the new Constitution sets out a pattern that gives the national Parliament broad legislative powers, while relying heavily on the provinces for the implementation of national policy. In return, provinces have a potentially powerful say in the national policy-making process. Provinces do not yet have effective taxation powers, and receive the overwhelming share of their income from intergovernmental transfers and grants. Local governments, however, are expected to cover most of their expenditure with own revenues. 
South Africa's constitutional design resembles the shared model of government. The following are strong parallels between the German and South African systems: the emphasis on concurrent functions, regional representation in the national law-making process, the reliance on subnational administrations for the implementation of national policies, the sharing of main revenue sources, and the evening out of disparities through a redistributing system of intergovernmental transfers and grants.

An assessment of the functionality of the fiscal federalism in South Africa is possible by comparing the design of the system with the economic reference frameworks for the assignment of expenditure responsibilities, sources of revenue, and the design of a system of intergovernmental transfers and grants.

Expenditure assignment in South Africa is largely congruent with the theoretical framework recommendations. Several differences occur, however, reflecting a more centralised approach in South Africa.

Table 29: Expenditure Assignment in Theory and in South Africa

\begin{tabular}{|c|c|c|c|c|}
\hline & \multicolumn{2}{|c|}{ Theoretical framework } & \multicolumn{2}{|c|}{ South Africa } \\
\hline Expenditure category & Regulation & Administration & Regulation & Administration \\
\hline Defence & $\mathrm{N}$ & $\mathrm{N}$ & $\mathrm{N}$ & $\mathrm{N}$ \\
\hline Foreign affairs & $\mathrm{N}$ & $\mathrm{N}$ & $\mathrm{N}$ & $N$ \\
\hline Intemational trade & $N$ & $N$ & $\mathrm{~N}$ & $N$ \\
\hline Currency and banking & $\mathrm{N}$ & $N$ & $\mathrm{~N}$ & $\mathrm{~N}$ \\
\hline Immigration & $\mathbf{N}$ & $N$ & $N$ & $N$ \\
\hline Unemployment insurance & $\mathrm{N}$ & $N$ & $\mathrm{~N}$ & $N$ \\
\hline Airlines and railways & $N$ & $N$ & $N$ & $\mathrm{~N}$ \\
\hline Natural resources & $\mathrm{N}$ & $N, R, L$ & $\mathbf{N}$ & $\mathrm{N}$ \\
\hline Environment & $N, R, L$ & $\mathrm{R}, \mathrm{L}$ & $N, R$ & $\mathrm{R}$ \\
\hline Industry & $N, R, L$ & $\mathrm{R}, \mathrm{L}$ & $N, R$ & $N, R$ \\
\hline Agriculture & $N, R, L$ & $\mathrm{R}, \mathrm{L}$ & $N, R$ & $\mathrm{R}$ \\
\hline Education & $N, R, I_{.}$ & $\mathrm{R}, \mathrm{L}$ & $N, R$ & $N, R$ \\
\hline Health & $N, R, L$ & $\mathrm{R}, \mathrm{L}$ & $N, R, L$ & $N, R, L$ \\
\hline Social welfare & $N, R, L$ & $\mathrm{R}, \mathrm{L}$ & $\mathrm{N}, \mathrm{R}$ & $\mathrm{R}$ \\
\hline Highways and roads & $N, R, L$ & $R, L$ & $N, R, L$ & $N, R, L$ \\
\hline Police & $\mathrm{R}, \mathrm{L}$ & $\mathrm{R}, \mathrm{L}$ & $\mathrm{N}, \mathrm{R}^{*}$ & $N, R, L^{*}$ \\
\hline Fire protection & $\mathbf{L}$ & $\mathrm{L}$ & $\mathrm{L}$ & $\mathbf{L}$ \\
\hline Water, refuse, sewerage & $\mathbf{L}$ & $\mathrm{L}$ & $\mathrm{L}$ & $\mathrm{L}$ \\
\hline
\end{tabular}

With regard to education, the framework recommends regional and local govemments as administrators. The South African Constitution assigns the executive responsibility for primary and secondary education to provinces, while the national government is admin- 
istratively responsible for tertiary institutions. This divergence is understandable from a historical perspective. The development of the former white universities was ensured by their historical funding privileges and the wealth of the constituency for which they were reserved. Many institutions in the former homelands, to the contrary, were creatures of apartheid and its notion of separate development. Many of the latter suffer from student debts, which are crippling administrations. There is also a distortion in the distribution of tertiary institutions across the country. The Northern Cape, for instance, has no university of its own (Van Niekerk and Ludman 1999: 67-68). In recognition of these circumstances, tertiary education has to be regarded as a national, rather than a regional, asset. This does not preclude the possibility of devolving authority at some later stage once the landscape of tertiary education has been reformed. As local structures have been subject to a challenging restructuring process over the past years, and many have a long way to go before they fulfil their role as providers of essential services, it is not advisable to burden them with responsibility for primary education at this stage.

Perhaps the most notable divergence between the framework and South African practice is in the area of policing. Although schedule 4 of the Constitution lists policing as a concurrent matter, the activity of provinces is de facto limited largely to an oversight role in other parts of the document (sections 205-208). Municipal policing, subject to section 206(7) of the Constitution, awaits comprehensive development (Committee Appointed by the Minister for Safety and Security 1997). In favour of continued centralisation is the task of transforming the South African Police Service (SAPS). The policy service served to sustain a system of oppression during apartheid. Dealing with the post-1994 challenge of fighting crime and lawlessness, however, requires an efficient and transformed police service that is trusted by all communities (Van Niekerk and Ludman 1999: 273-276). It can be argued that such a challenge demands central guidance.

With regard to welfare the comparison does not generate an answer as to where the budgeting function for social entitlements should be located. This analysis noted three possible developments: reflecting welfare grants in the budget vote of the national department, "top-slicing" the cost for such entitlements before revenue-sharing, or giving provinces greater autonomy in determining welfare entitlements. Whichever option is chosen, it is recommended that budgeted amounts be fully aligned with expenditure requirements according to cleaned-up beneficiary data. 
It is on the revenue side that the most fundamental difference must be noted, as tax assignment remains centralised. The political accountability of provincial governments is hampered in the current situation. The provinces cannot finance their own priorities through additional taxation, for which a provincial authority would be accountable to its electorate. Rapoo (1995: 13-14) points out that an arrangement without effective provincial taxation powers "creates a situation not unlike that in the former 'homelands' system in which, because allocations are decided by the centre, provinces are not responsible to their electorates for spending - shortfalls can simply be blamed on central government."

Table 30: Revenue Assignment in Theory and in South Africa

\begin{tabular}{lcccccc} 
& \multicolumn{3}{c}{ Theoretical framework } & \multicolumn{3}{c}{ South Africa } \\
\hline & \multicolumn{2}{c}{ Determination of } & \multicolumn{2}{c}{ Determination of } \\
\hline Revenue source & Base & Rate & $\begin{array}{c}\text { Collection and } \\
\text { administration }\end{array}$ & Base & Rate & $\begin{array}{c}\text { Collection and } \\
\text { administration }\end{array}$ \\
\hline Customs & $\mathrm{N}$ & $\mathrm{N}$ & $\mathrm{N}$ & $\mathrm{N}$ & $\mathrm{N}$ & $\mathrm{N}$ \\
Corporate income & $\mathrm{N}$ & $\mathrm{N}$ & $\mathrm{N}$ & $\mathrm{N}$ & $\mathrm{N}$ & $\mathrm{N}$ \\
Natural resources & $\mathrm{N}$ & $\mathrm{N}$ & $\mathrm{N}$ & $\mathrm{N}$ & $\mathrm{N}$ & $\mathrm{N}$ \\
VAT & $\mathrm{N}$ & $\mathrm{N}$ & $\mathrm{N}$ & $\mathrm{N}$ & $\mathrm{N}$ & $\mathrm{N}$ \\
Personal income & $\mathrm{N}$ & $\mathrm{N}, \mathrm{R}$ & $\mathrm{N}$ & $\mathrm{N}$ & $\mathrm{N}, \mathrm{R}^{*}$ & $\mathrm{~N}$ \\
Retail sales & $\mathrm{R}$ & $\mathrm{R}, \mathrm{L}$ & $\mathrm{R}, \mathrm{L}$ & $\mathrm{N}$ & $\mathrm{N}$ & $\mathrm{N}$ \\
or & $\mathrm{N}$ & $\mathrm{R}$ & $\mathrm{N}$ & & & \\
Property & $\mathrm{R}$ & $\mathrm{L}$ & $\mathrm{L}$ & $\mathrm{N}, \mathrm{L}$ & $\mathrm{L}$ & $\mathrm{L}$ \\
Fees, user charges & $\mathrm{N}, \mathrm{R}, \mathrm{L}$ & $\mathrm{N}, \mathrm{R}, \mathrm{L}$ & $\mathrm{N}, \mathrm{R}, \mathrm{L}$ & $\mathrm{N}, \mathrm{R}, \mathrm{L}$ & $\mathrm{N}, \mathrm{R}, \mathrm{L}$ & $\mathrm{N}, \mathrm{R}, \mathrm{L}$ \\
Excises & $\mathrm{R}, \mathrm{L}$ & $\mathrm{R}, \mathrm{L}$ & $\mathrm{R}, \mathrm{L}$ & $\mathrm{N}$ & $\mathrm{N}$ & $\mathrm{N}$ \\
\hline Sounces
\end{tabular}

Souree. Theoretical framework adapted from Shah (1994a: Table 1.4 and 1994b: Table 6). South African data according to the Constitution of the Republic of South Africa (1996), sections 228 and 229.

Notes. $\mathrm{N}=$ national government, $\mathrm{R}=$ regional government, $\mathrm{L}=$ local government.

* Provincial taxation powers are not effective yet, as national regulatory legislation is required (section $228(2)(b))$. This legislation is still outstanding at the time of writing.

The importance of intergovermmental transfers and grants for provinces and poor and smaller local authorities is substantial. An assessment of the South African system, based on the theoretical criteria that were outlined, is somewhat more subjective than the questions of assignment discussed above. Adequacy, predictability and incentive are the problem areas that were identified in this analysis. Whether the system provides adequate income to the spheres is difficult to assess, since the rationale behind the vertical division of revenue is not obvious and there is a lack of information as to how it was calculated. However, provincial allocations have been decreasing, while local government allocations reflect historical resource flows despite a broadening of mandates. This issue deserves further research. Predictability has been hampered by successive changes to the criteria guiding the horizontal distribution of the provincial equitable share. Incentives for sound financial management at the provincial and local levels will remain weak as long as the respective 
formulas for the horizontal distribution do not emphasise revenue criteria, which discourages efforts to increase own revenues and hampers accountability.

Table 31: Proposed Rating of Intergovernmental Transfers and Grants in South Africa

\begin{tabular}{|c|c|c|}
\hline Criteria & $\begin{array}{l}\text { South African } \\
\text { Rating }\end{array}$ & Comments \\
\hline Autonomy & Medium. & $\begin{array}{l}\text { Provincial equitable share to provinces is unconditional, but de- } \\
\text { tailed norms and standards are imposed by national legislation. }\end{array}$ \\
\hline Revenue Adequacy & Low. & $\begin{array}{l}\text { Rationale behind the vertical division of revenue is not obvious. } \\
\text { Provincial allocations have been decreasing, while local govem- } \\
\text { ment allocations reflect historical resource flows. }\end{array}$ \\
\hline Equity & High. & $\begin{array}{l}\text { Formulas for the horizontal distribution of the provincial and } \\
\text { local government shares are needs-driven and favour poor areas. }\end{array}$ \\
\hline Predictability & $\begin{array}{l}\text { Potentially high, } \\
\text { but so far low in } \\
\text { practice. }\end{array}$ & $\begin{array}{l}\text { Formula-approach for horizontal distributions is more predict- } \\
\text { able than ad hoc allocations. Successive changes to the criteria } \\
\text { guiding the horizontal distribution of the provincial equitable } \\
\text { share have been partially due to the incorporation of new data. }\end{array}$ \\
\hline Efficiency & Medium. & $\begin{array}{l}\text { Allocations are overwhelmingly unconditional, which enables } \\
\text { spending pattems to reflect varying needs. However, very de- } \\
\text { tailed national norms and standards limit room for provincial } \\
\text { expenditure prionitisation. }\end{array}$ \\
\hline Simplicity & Medium to high. & $\begin{array}{l}\text { New component in provincial horizontal formula and related } \\
\text { adjustments make formula more complex. }\end{array}$ \\
\hline Incentive & Low. & $\begin{array}{l}\text { Formulas do not emphasise revenue criteria, which discourages } \\
\text { efforts to increase own revenues and hampers accountability. }\end{array}$ \\
\hline $\begin{array}{l}\text { Safeguard of gran- } \\
\text { tor's objectives }\end{array}$ & $\begin{array}{l}\text { Medium to } \\
\text { strong. }\end{array}$ & $\begin{array}{l}\text { Detailed norms and standards imposed on provinces through } \\
\text { national legislation. }\end{array}$ \\
\hline
\end{tabular}

Soume. Criteria in column one according to Shah (1994a: 33-34).

While economic theory may not be useful to determine a specific design for regulating subnational borrowing activities, it nonetheless indicates that subnational borrowing is recommended to finance capital expenditure. 'The South African Constitution applies the so-called "golden rule" by restricting provincial and local borrowing to amounts necessary to finance capital projects (apart from bridging purposes). The borrowing powers of provinces, however, have not been functional so far. Effective provincial borrowing is necessary to boost dwindling capital expenditure at this level, in order to address backlogs and extend service provision to all communities. While local governments in South Africa engage in borrowing activities, it can be hoped that redemarcation will be able to facilitate a more even access to the capital market. 
In summary, on the expenditure side, there is substantial congruence between what is theoretically desirable and what the Constitution permits. In the medium to long-term, once transitional challenges have been overcome, there are arguments in favour of greater provincial and local responsibility in areas that have primarily local benefits. Revenue assignment, on the other hand, remains centralised although the theoretical framework indicates a number of sources that are suitable for provincial governments. The provincial taxation powers contained in the Constitution should be implemented to establish the link between expenditure and revenue that forms the basis of public finance. The current system of intergovernmental transfers and grants has achieved substantial equity. Further developments should be concerned with ensuring revenue adequacy for all spheres and providing incentives for sound financial management, while maximising the predictability inherent in the formula approach by avoiding year-on-year adaptations. The borrowing powers of provinces contained in the Constitution need to be activated to enable a greater focus on developmental expenditures.

This analysis indicates that the constitutional assignment of functions and resources as such cannot be blamed for a lack of governmental efficacy that has been experienced, and should be fully implemented. However, the analysis of the South African system pointed out several areas that have impeded the smooth running of the governmental system. It remains to be discussed how these problems can be addressed.

Corruption. Corruption is partially linked to procurement procedures, which are multiplied at subnational level. It has also been described as an overhang from the previous dispensation, indicating that it is not inherently related to decentralisation. Clear procurement procedures and vigorous prosecution seem best suited to address this problem.

Capacity. The rural and underdeveloped provinces in some instances had to amalgamate several formerly separate administrations into one new provincial administration. Similarly, many newly created local authorities could not rely on an established service structure. However, even if services were centralised, administration would rely on the same public servants and their bureaucratic infrastructure. Rather, a drastic lack of capacity in some instance might be resolved by a temporary asymmetrical approach, in line with the Constitution (sections 41(1), 100, 125(3), 139 and 155(6)). As the Presidential Review Commission (1998: 44) recommended: "Serious consideration should be given to the asymmetrical 
devolution of functions [emphasis in the original] (i.e. the devolution of some of the functions to provinces and municipalities where there is capacity to undertake services rather than delaying such devolution until there is capacity overall) as has been proposed by the Department of Housing. This could go some way to redress problems of capacity violating the provisions of the Constitution." However, the notion of co-operative government as a partnership between the spheres requires that any short-term interventions are ultimately aimed at restoring the capacity of the authority in question to effectively comply with its executive obligations.

Mandates. The Ncholo Report noted that national departments tended to assume that their policy would automatically become activity. More careful planning and the costing of mandates would strengthen the ability of the provinces to implement national standards. The NCOP is well-placed to consider the administrative and financial impact on provinces of mandates contained in national legislation. This role should be developed, for instance by enhancing the research capacity of the council. Rather than reducing provinces to "conveyor belts for the centre" (Friedman 1999: 46), a greater degree of flexibility through less detailed norms and standards could also enable provinces to set individually suitable and realistic targets.

Personnel Expenditure. Rising personnel expenditure ratios across provinces threaten to undermine their developmental ability by squeezing out developmental expenditure. The ability of provinces to control their personnel expenditure, however, is highly limited due to the centralised wage bargaining process and the continued absence of an affordable retrenchment tool. Provinces require a national policy on retrenchments, or they need to be empowered to design their own. Consideration should also be given to the possibility of decentralising the wage bargaining process for public servants.

None of these problem areas are systemic; they are not inherently connected to the design of intergovernmental fiscal relations, and there is no evidence to suggest that they could be addressed by adjustments to the assignment of functions and resources.

In conclusion, economic theory indicates that the constitutional assignment of responsibilities and resources to the different spheres in South Africa should not be adjusted for the sake of greater efficiency. However, the challenge remains to implement the system 
fully and properly, identify areas of concern, and to manage teething problems and transitional difficulties proactively. Decentralisation includes a learning process, and newly created structures and institutions need to be developed and strengthened before they can be expected to deliver the full benefits of decentralised government. 


\section{BIBLIOGRAPHY}

\section{a) Literature}

Abedian, Iraj, Tania Ajam and Laura Walker 1997: Promises, Plans, Prionities. South Africa's Emerging Fiscal Structures, Cape Town (Idasa: Budget Information Service).

African National Congress 1994: The Reconstruction and Development Programme, Johannesburg (Umanyano Publications).

Ahmad, Ehtisham and Jon Craig 1997: Intergovernmental Transfers; in: Teresa TerMinassian (ed.): Fiscal Federalism in Theory and Practice, Washington (International Monetary Fund): 73-107.

Ahmad, Ehtisham, Daniel Hewitt and Edgardo Ruggiero 1997: Assigning Expenditure Responsibilities; in: Teresa Ter-Minassian (ed.): Fiscal Federalism in Theory and Practice, Washington (International Monetary Fund): 25-48.

Ahmad, Junaid 1996: The Structure of Urban Governance in South African Cities, International Tax and Public Finance Vol. 3: 193-213.

Ajam, Tania 1997: Study on the National and Provincial Budget Processes (prepared for the Presidential Review Commission on Public Sector Reform, 22 October).

Ajam, Tania 1998: NCOP challenged to make bigger impact on Budget; in: Budget Watch Vol. 4 Issue 2 (June): 2.

Banting, Keith G. and Richard Simeon (eds) 1985: Redesigning the State: The Politics of Constitutional Change, Toronto (University of Toronto Press).

Barberton, Conrad 1998: PSC's vision of social security short-sighted; in: Budget Watch Vol. 4 Issue 2 (June): 4. 
Besdziek, Dirk 1998: Provincial Government, in: Albert Venter (ed.): Government and Politics in the New South Africa, Pretoria (J. L. van Schaik): 147-192.

Bhabha, Mohammed 1997: The Role of Local Government in the National Council of Provinces (paper presented at Idasa, Cape Town, 22 July).

Biehl, Dieter 1994: Intergovernmental Fiscal Relations and Macroeconomic Management - Possible Lessons from a Federal Case: Germany; in: S. P. Gupta et al (eds): Intergovernmental Fiscal Relations and Macroeconomic Management in Large Countries, New Delhi etc. (Allied Publishers): 68-115.

Bird, Richard M. 1993: Threading the Fiscal Labyrinth: Some Issues in Fiscal Decentralization; in: National Tax Journal Vol. XLVI No. 2 (June): 207-227.

Bird, Richard M. and Duan-jie Chen 1998: Federal finance and fiscal federalism: the two worlds of Canadian public finance; in: Canadian Public Administration Vol. 41 No. 1: 51-74.

Bramley, Glen 1990: Equalization Grants and Local Expenditure Needs. The Price of Equality, Aldershot etc. (Avebury).

Brosio, Giorgio and Sanjeev Gupta 1997: Ethiopia; in: Teresa Ter-Minassian (ed.): Fiscal Federalism in Theory and Practice, Washington (International Monetary Fund): 504-526.

Bulpitt, Jim 1996: Federalism; in: Iain McLean (ed.): Oxford Concise Dictionary of Politics, Oxford (Oxford University Press): 179-180.

Bundesministerium der Finanzen 1996: Das Hausbaltssystem der Bundesnepublik Deutschland, Bonn.

Bundesministerium der Finanzen 1997: Finanzpolitik für die Deutsche Einbeit. Fakten, Bonn.

Bundesministerium der Finanzen 1998: Die Finanzverteilung in der Bundesrepublik Deutschland, Bonn. 
Burgess, Michael and Alain-G. Gagnon 1993 (eds): Comparative Federalism and Federation. Competing Traditions and Future Directions, New York etc. (Harvester Wheatsheaf).

Burgess, Michael and Franz Gress 1993: The Quest for a Federal Future: German Unity and European Union; in: Michael Burgess and Alain-G. Gagnon (eds): Comparative Federalism and Federation. Competing Traditions and Future Directions, New York etc. (Harvester Wheatsheaf): 168-186.

Cameron, Robert 1996: Local Government Boundary Demarcation: The Case of the Western Cape Metropolitan Area Substructures; in: Politikon Vol. 23 No. 1: 21-42.

Campbell, Tim et al 1991: Decentralization to Local Government in LAC: National Strategies and Local Response in Planning, Spending and Management, Washington D.C. (World Bank).

Cape Metropolitan Council et al 1997: Towards Effective Metropolitan Governance for the Cape Metropolitan Area (submission from local government in the Cape metropolitan area at public hearings in Parliament on metropolitan government and the Green Paper, 3 November, Cape Town).

Cashin, Paul and Ratna Sahay 1995: Internal Migration, Center-State Grants and Economic Growth in the States of India, IMF Working Paper 95/58 (August).

Chelliah, Raja J. 1994: Intergovernmental Fiscal Relations and Macroeconomic Management in India; in: S. P. Gupta et al (eds): Intergovernmental Fiscal Relations and Macroeconomic Management in Large Countries, New Delhi etc. (Allied Publishers): 188-212.

Cherry, Janet 1994: Development, Conflict and the Politics of Ethnicity in South Africa's Transition to Democracy; in: Third World Quarterly Vol. 15 No. 4: 613-631.

Chothia, Farouk 1998: Now is the time to be nice to your rivals; in: Business Day, 29 April.

Christopher, A. J. 1994: The Atlas of Apartheid, Johannesburg (Witwatersrand University Press). 
Commission of Inquiry into certain Aspects of the Tax Structure of South Africa 1998: Seventh Interim Report of the Commission of Inquiry into certain Aspects of the Tax Structure of South Africa. Synthesis of Policy Recommendations with regard to Provincial Taxation, 14 July, Johannesburg.

Committee Appointed by the Minister for Safety and Security 1997: Report of the Committee Appointed by the Minister for Safety and Security on Decentralisation of Policing Functions, Devolution of Political Authority, Municipal and Metropolitan Policing, and Civilian / Political Oversight, 31 May.

Constitutional Assembly (Theme_Committee 3: Relationship between levels of government) 1995: Memorandum on Federalism (Revised Version by D. M. Davis), 27 March.

Cotler, Irwin 1996: Can the Center Hold? Federalism and Rights in Canada; in: Ellis Katz and G. Alan Tarr (eds): Federalism and Rights, London (Rowman \& Littlefield Publishers): 173-191.

Craig, Jon 1997: Australia; in: Teresa Ter-Minassian (ed.): Fiscal Federalism in Theory and Practice, Washington (International Monetary Fund): 175-200.

Craig, Jon, John Norregaard and George Tsibouris 1997: Russian Federation; in: Teresa Ter-Minassian (ed.): Fiscal Federalism in Theory and Practice, Washington (International Monetary Fund): 680-701.

Cullinan, Kerry 1999: A Tale of Two Towns; in: Siyaya! Issue 4 (Autumn), Idasa (Cape Town): 4-9.

De Villiers, Bertus (ed.) 1994a: Birth of a Constitution, Kenwyn (Juta).

De Villiers, Bertus 1994b: Intergovernmental Relations: A Constitutional Framework; in: Bertus de Villiers (ed.): Birth of a Constitution, Kenwyn (Juta): 256- 280.

De Villiers, Bertus 1997a: Local-Provincial Relations: A Comparative Perspective, Konrad Adenauer Foundation Occasional Paper (May), Johannesburg (Konrad Adenauer Foundation). 
De Villiers, Bertus 1997b: Intergovernmental Relations in South Africa; in: South African Public Law Vol. 12: 197-213.

Department of Constitutional Dévelopment (various issues): Project Viability Report, Pretoria.

Department of Constitutional Development 1999: Strategic Issues and Options for Poligy on Co-operative Government and Intergovernmental Relations (second draft of a discussion document prepared for the Conference on Intergovernmental Relations and Provincial Government: Fostering Mutual Co-operation, 29 and 30 March, Gallagher Estate, Midrand).

Department of Finance 1997a: Budget Review 1997, Pretoria.

Department of Finance 1997b: Medium Term Budget Policy Statement, 2 December, Pretoria.

Department of Finance 1998a: Budget Review 1998, Pretoria.

Department of Finance 1998b: The Introduction of an Equitable Share of Nationally Raised Revenue for Local Government, 21 April, Pretoria.

Department of Finance 1998c: Medium Term Budget Policy Statement, 2 November, Pretoria.

Department of Finance 1999: Budget Review 1999, 17 February, Pretoria.

Department of Provincial Affairs and Constitutional Development and Department of Finance 1997: The present state of municipal finance, and actions taken by government to address the situation (memorandum, $18 \mathrm{March}$ ).

Deutsches Institut für Wirtschaftsforschung 1996: Sind die Finanzprobleme in Ostdeutschland durch die Neuordung des Finanzausgleichs gelöst?, DIW Wochenbericht Vol. 69 No. 17. 
Dollery, Brian 1998: An Initial Evaluation of Revenue-Sharing Arrangements in the New South African Fiscal Federalism; in: Publius Vol. 28 No. 2: 129-153.

Donian, Colin and Colleen Rip-Botha 1997: Census results impact on policy and budgeting, in: Budget Watch Vol. 3 Issue 3 (September): 5.

Elazar, Daniel J. 1991 (ed.): Federal Systems of the World: A Handbook of Federal, Confederal, and Autonomy Arrangements, Harlow (Longman Current Affairs).

Elazar, Daniel J. 1995: Federalism : An Overview, Federalism Theory and Application Vol. 1, Pretoria (Human Sciences Research Council).

Financial and Fiscal Commission 1995: Framework Document for Intergovernmental Fiscal Relations in South Africa, May, Midrand.

Financial and Fiscal Commission 1996: The Financial and Fiscal Commission's Recommendations for the Allocation of Financial Resources to the National and Provincial Governments for the 1997/98 Financial Year, May, Midrand.

Financial and Fiscal Commission 1997: Local Government in a System of Intengovernmental Fiscal Relations in South Africa. A Discussion Document, 25 July, Midrand.

Financial and Fiscal Commission 1998a: Recommendations \&o Comments - The Allocation of Financial Resources to National, Provincial and Local Governments for the 1998/99 Fiscal Year, Submitted in Terms of Section 9 of the Intergovernmental Fiscal Relations Act, 1997, 9 January, Midrand.

Financial and Fiscal Commission 1998b: Should social security grants be the jurisdiction of the national or provincial government? (draft report, 9 December).

Financial and Fiscal Commission 1999: Terms of Reference for Project 2001. FFC Formula Development for the 2001/02 and Subsequent Fiscal Years (draft, 7 April). 
Fitschen, Amanda 1999: What's good for provincial welfare?; in: Mail \& Guardian, 5 March.

Fölscher, Alta 1999: Provincial borrowing framework under review; in: Budget Watch (June): 2-3.

Franks, Darwin 1998: $A$ Report to the NCOP (case study of the intervention by the Eastern Cape Provincial Government in Butterworth Municipality, presented to the National Council of Provinces on 27 September).

Friedman, Steven 1999: Power to the Provinces!; in: Siyaya! Issue 4 (Autumn), Idasa (Cape Town): 44-46.

Führ, Christoph 1997: The German Education System since 1945. Outlines and Problems, Bonn (Inter Nationes).

Gildenhuys, J. S. H. 1997: Introduction to Local Government Finance. A South African Perspective, Pretoria (J. L. van Schaik).

Government of Canada 1999: A Framework to Improve the Social Union for Canadians (agreement between the Government of Canada and the Governments of the Provinces and Territories, 4 February).

Gray, Cheryl W. and Daniel Kaufmann 1998: Corruption and Development; in: Finance and Development Vol. 35 No. 1 (March).

Gray, Gwen and Rodney F. White 1989: Federalism and the Evolution of Public Hospital and Medical Coverage; in: Hodgins, Bruce W. et al (eds): Federalism in Canada and Australia. Historical Perspectives 1920-88, Peterborough / Canada (Frost Centre for Canadian Heritage and Development Studies): 279-300.

Griggs, Richard 1997: Voting makes a lot more sense; in: Mail \& Guardian, 25 July. 
Gullo, Theresa A. and Janet M. Kelley 1998, Federal Unfunded Mandate Reform: A First-Year Retrospective; in: Public Administration Review Vol. 58 No. 5: 379-387.

Gupta, S. P. et al (eds) 1994: Intergovernmental Fiscal Relations and Macroeconomic Management in Large Countries, New Delhi etc. (Allied Publishers).

Hartzenberg, Trudi 1995: Clarity needed for function committees; in: Budget Watch Vol. 1 Issue 5 (December): 4.

Hemming, Richard, Neven Mates and Barry Potter 1997: India; in: Teresa Ter-Minassian (ed.): Fiscal Federalism in Theory and Practice, Washington (International Monetary Fund): 527-539.

Hesse, Joachim Jens and Thomas Ellwein 1992: Das Regierungssystem der Bundesrepublik Deutschland ( $7^{\text {th }}$ edition), Opladen (Westdeutscher Verlag).

Hesse, Joachim Jens and Thomas Ellwein 1997: Das Regierungssystem der Bundesrepublik Deutschland ( $8^{\text {th }}$ edition), Opladen (Westdeutscher Verlag).

Hesse, Konrad 1962: Der unitarische Bundesstaat, Karlsruhe (C.F. Müller).

Heyns, J. v. d. S. 1995: Equity and Redistribution in South Africa. Some Fiscal Federalism Perspectives; in: South African Journal of Economics Vol. 63 No. 2: 150-172.

Hobson, Paul A. R. and France St-Hilaire 1993: Towards sustainable federalism: reforming federal-provincial fiscal arrangements, Montreal (Institute for Research on Public Policy).

Hodgins, Bruce W. et al (eds) 1989: Federalism in Canada and Australia. Historical Perspectives 1920-88, Peterborough / Canada (Frost Centre for Canadian Heritage and Development Studies).

Hopley, Henry 1998: An Overview of the 1998/99 Northern Cape Provincial Budget, Cape Town (Idasa: Budget Information Service). 
Horowitz, D. L. 1991: A Democratic South Africa? Constitutional Engineering in a Divided Society, Berkeley (University of California Press).

Inkatha Freedom Party et al 1993: Joint submission of the Inkatha Freedom Party, the kwaZulu government, the Afrikaner Volksunie, the Conservative Party, the Bophuthatswana government and the Ciskei government to the Technical Committee on Constitutional Matters and to the Negotiating Council on a process of transformation capable of establishing, amongst others, federalism, 28 June.

Inkatha Freedom Party 1998: Amendments to the Constitution of the Republic of South Africa Proposed by the Inkatha Freedom Party.

International Monetary Fund (annually): Government Finance Statistics Yearbook, Washington D.C. (Intemational Monetary Fund).

Isensee, Josef 1968: Subsidiaritätsprinzip und Verfassungsrecht. Eine Studie über das Regulativ des Verbältnisses von Staat und Gesellschaft (Schriften zum Öffentlichen Recht, Band 80), Berlin (Duncker \& Humblot).

Ismail, Nazeem and Chisepo J. J. Mphaisha 1997: The Final Constitution of South Africa: Local Government Provisions and their Implications, Konrad Adenauer Foundation Occasional Paper (January), Johannesburg (Konrad Adenauer Foundation).

Kendle, John 1997: Federal Britain. A History, London (Routledge).

Klitgaard, Robert 1998: International Cooperation Against Corruption; in: Finance and Development Vol. 35 No. 1 (March).

Krafchik, Warren and Joachim Wehner 1998a: Confusion over NCOP's role in process; in: Budget Watch Vol. 4 Issue 2 (June): 3.

Krafchik, Warren and Joachim Whehner 1998b: The Role of Parliament in the Budgetary Process; in: South African Journal of Economics Vol. 66 No. 4: 512-541. 
Krelove, Russel, Janet G. Stotsky and Charles L. Vehorn 1997: Canada; in: Teresa TerMinassian (ed.): Fiscal Federalism in Theory and Practice, Washington (International Monetary Fund): 201-225.

Kriek, Dan J. 1994: The new form of state in South Africa: a true federation?; in: Politeia Vol. 13 No. 1: 118-120.

Kriek, Dan J. 1996: Unie of federasie?; in: Politeia Vol. 15 No. 2: 62-64.

Ladd, Helen F. and John Yinger 1994: The Case for Equaliszing Aid; in: National Tax Journal Vol. XLVII No. 1: 211-224.

Laufer, Heinz and Ursula Münch 1997: Das foderative System der Budesrepublik Deutschland, Bonn (Bundeszentrale für politische Bildung).

Leslie, Peter M. 1988: National Citizenship and Provincial Communities: A Review of Canadian Fiscal Federalism, Research Paper No. 23, Kingston / Ontario (Queen's University: Institute of Intergovernmental Relations).

Lodge, Tom 1995: The South African General Election, April 1994: Results, Analysis and Implications; in: African Affairs Vol. 94: 471-500.

Lodge, Tom 1999: South African Politics Since 1994, Cape Town (David Philip Publishers).

MacGregor, John, Stephen Peterson and Claudio Schuftan 1998: Downsizing the civil service in developing countries: the golden handshake option revisited; in: Public Administration and Development Vol. 18 No. 1: 61-76.

Makhanya, Mosila David 1998: An Overvien of the 1998/99 Free State Provincial Budget, Cape Town (Idasa: Budget Information Service).

Mashabela, Harry 1990: Mekbukbu. Urban African Cities of the Future, Johannesburg (South African Institute of Race Relations). 
Mattes, Robert 1995: The Election Book. Judgement and Choice in South Africa's 1994 Election, Cape Town (Idasa: Public Opinion Service).

Mbeki, Thabo 1999: Keynote Address (paper presented at the Conference on Intergovernmental Relations and Provincial Government: Fostering Mutual Co-operation, 29 March, Gallagher Estate, Midrand).

McCarthy, Jeff 1993: Factual Context to Political Competition; in: Development and Democracy: The Regional Question, 5 July, Johannesburg (Urban Foundation): 39-49.

McLure, Charles E. Jr. 1994: Intergovernmental Fiscal Relations in South Africa: The Assignment of Expenditure Functions and Revenue Sources and the Design of Intergovernmental Grants and Transfers, June 20 (World Bank discussion document).

Milne, David 1993: Whither Canadian Federalism? Alternative Constitutional Futures; in: Michael Burgess and Alain-G. Gagnon (eds): Comparative Federalism and Federation. Competing Traditions and Future Directions, New York etc. (Harvester Wheatsheaf): 203-226.

Ministry for Provincial Affairs and Constitutional Development 1997: Green Paper on Local Government, October, Pretoria.

Ministry for Provincial Affairs and Constitutional Development 1998a: White Paper on Local Government, March, Pretoria.

Ministry for the Public Service and Administration 1997: The Provincial Review Report, Pretoria.

Mokgoro, Job 1994: Interprovincial Fiscal Equalization: The Role of the Financial and Fiscal Commission; in: Bertus de Villiers (ed.): Birth of a Constitution, Kenwyn (Juta): 281 293.

Msimango, Luvuyo 1998: An Overview of the 1998/99 Eastern Cape Provincial Budget, Cape Town (Idasa: Budget Information Service). 
Murray, Christina 1998: NCOP offers provinces role in Budget process; in: Budget Watch Vol. 4 Issue 2 (June): 1.

Murray, Christina and Richard Simeon 1998: From paper to practice: the National Council of Provinces after its first year (unpublished paper).

Musgrave, R. A. 1959: The Theory of Public Finance. A Study in Public Economy, New York (McGraw-Hill).

Nathan, Richard P. and Margarita M. Balmaceda: Comparing Federal Systems of Government; in: Robert J. Bennett (ed.): Decentralization, Local Governments, and Markets. Towards a Post-Welfare Agenda, Oxford (Clarendon Press): 59-77.

National Council of Provinces 1998: NCOP News. Newsletter of the National Council of Provinces (March), Cape Town.

National Council of Provinces 1999a: National Council of Provinces 1996-1999 in Review, Cape Town.

National Council of Provinces 1999b: The Imperative of Co-operative Governance. Report of the National Council of Provinces. National Conference of 8-9 May 1998, Cape Town.

National Council of Provinces 1999c: Provincial Comparative Study. Report of the National Council of Provinces, Cape Town.

Newham, Gareth 1997: Legislature battles the budget; in: Provincial Whip, 11 August: 2-3.

Newton, Michael T. 1997: Institutions of Moder Spain. A Political and Economic Guide, Cambridge (Cambridge University Press).

Norregaard, John 1997: Tax Assignment; in: Teresa Ter-Minassian (ed.): Fiscal Federalism in Theory and Practice, Washington _Intemational Monetary Fund): 49-72. 
O'Malley, Kierin 1994: The interim constitution: a figleaf for federalism?; in: Politeia Vol. 13 No. 1: 121-123.

Oates, Wallace E. 1993 (first published in 1972): Fiscal Federalism, Aldershot (Gregg Revivals).

Oates, Wallace E. 1994: Federalism and Government Finance; in: John M. Quigley and Eugene Smolensky (eds): Modern Public Finance, Cambridge, Massachusetts (Harvard University Press): 126-151.

Oliveira, João do Carmo and Raul Velloso 1994: Intergovernmental Fiscal Relations in Brazil. Trends and Issues; in: S. P. Gupta et al (eds): Intengovernmental Fiscal Relations and Macroeconomic Management in Large Countries, New Delhi etc. (Allied Publishers): 122-187.

Pablos, Nicolas Pineda 1997: Fisçal Decentralization in Brazil; in: Policymaking in a Redemocratized Brazil, Policy Research Report No. 119, Austin (University of Texas: Lyndon B. Johnson School of Public Affairs).

Presidential Review Commission 1998: Developing a Culture of Good Governance. Report of the Presidential Review Commission on the Reform and Transformation of the Public Service in South Africa. Presented to the President of South Africa, Mr. N. R. Mandela, 27 February, Pretoria.

Prud'homme, Rémy 1995: The Dangers of Decentralization; in: World Bank Research Observer Vol. 10 No. 2 (August): 201-220.

Ramathodi, Ngoako 1998: Fresh look at levels of government needed; in: Business Day, 11 May.

Randall, Duncan J. 1998: The 1996 Municipal Elections in KwaZulu-Natal: An Eyewitness Account; in: Politikon Vol. 25 No. 1: 103-128.

Rao, M. Govinda and Francois Vaillancourt 1994: Interstate Tax Disharmony in India: A Comparative Perspective; in: Publius Vol. 24 No. 4: 99-114. 
Rapoo, Thabo 1995: A System in Dispute: Provincial Government in Practice, Policy: Issues and Actors Vol. 8 No. 10 (September), Johannesburg (Centre for Policy Studies).

Reddy, P.S. (ed.) 1996: Readings in Local Government Management and Development. A Soutberm African Perspective, Kenwyn (Juta).

Rudzio, Wolfgang 1991: Das Politische System der Bundesrepublik Deutschland, Opladen (Leske und Budrich).

Saunders, Cheryl 1995: Constitutional Arrangements in Federal Systems; in: Publius Vol. 25 No. 2: 61-79.

Scharpf, Fritz W. 1988: The Joint-Decision Trap: Lessons from German Federalism and European Integration; in: Public Administration Vol. 66 (Autumn): 239-278.

Schultze, Rainer-Olaf 1996: Föderalismus; in: Dieter Nohlen (ed.): Wörterbuch Staat und Politik, Bonn (Bundeszentrale für politische Bildung): 155-164.

Sehurutshe, "Scrooge" Otsile Wa Ga and Gerrick Newham 1998: The National Council of Provinces: Realising the potential; in: Provincial Whip, 22 January: 4-5.

Shah, Anwar 1994a: Perspectives on the Design of Intergovernmental Fiscal Relations in Developing Transition Economies; in: S. P. Gupta et al (eds): Intergovernmental Fiscal Relations and Macroeconomic Management in Lange Countries, New Delhi etc. (Allied Publishers): 168.

Shah, Anwar 1994b: The Reform of Intergovernmental Fiscal Relations in Developing and Emerging Market Economies, Policy and Research Series No. 23, Washington (World Bank).

Siebrits, F. K. 1997: The South African Government: Financial Relations, Expenditure and Employment, Report No. 239, Pretoria (Bureau of Market Research). 
Simeon, Richard 1972: Federal-prozincial diplomacy: the making of recent policy in Canada, Toronto (University of Toronto Press).

Simeon, Richard 1998: Considerations on the design of federations: the South African constitution in comparative perspective; in: South African Public Law Vol. 13: 42-71.

Simeon, Richard and Ian Robinson 1990: State, Society, and the Development of Canadian Federalism, Toronto (University of Toronto Press).

Simkins, Charles 1997: Reconciling Equity and Diversity. Provincial Budgets in Perspective; in: Budget Watch Vol. 3 No. 2 (June): 1.

Simon, David 1996: Restructuring the Local State in Post-Apartheid Cities: Namibian Experience and Lessons for South Africa; in: African Affairs Vol. 95 No. 379: 51-84.

Sindane, Jabu 1997: Discussion Paper on the Future of South African Politics; in: Hennie Kotzé (ed.): A Future South Africa? Prospects for 1999 and Beyond, Stellenbosch (University of Stellenbosch: Centre for International and Comparative Politics): 219-222.

Smith, Graham (ed.) 1995: Federalism: The Multiethnic Challenge, New York (Longman Publishing).

Solomon, David 1998: Local Government in South Africa: Challenges and Solutions, Cape Town (Idasa: Budget Information Service).

South African Local Government Association (Finance Working Group) 1998: Workshop on the equitable share of nationally raised revenue for local government, 17 August (summary document).

Southall, Roger 1994: The South African Elections of 1994: the Remaking of a Dominant-Party State; in: Journal of Modern African Studies Vol. 32 No. 4: 629-655. 
Spahn, Paul Bernard 1995: Local Taxation: Principles and Scope; in: J. Roy (ed.): Macroeconomic Management and Fiscal Decentralisation, EDI Seminar Series, Washington (World Bank).

Spahn, Paul Bernard and Wolfgang Föttinger 1997: Germany; in: Teresa Ter-Minassian (ed.): Fiscal Federalism in Theory and Practice, Washington (International Monetary Fund): 226-248.

Sparks, Allister 1994: Tomorrow is Another Country. The Inside Story of South Africa's Negotiated Revolution, Sandton (Struik Book Distributors).

Statistics South Africa 1998: The People of South Africa Population Census, 1996. Census in Brief, Report No. 03-01-11 (1996), Pretoria.

Steyn, Glen 1998: An Overview of the 1998/99 Northern Province Provincial Budget, Cape Town (Idasa: Budget Information Serviče).

Stotsky, Janet G. and Emil M. Sunley 1997: United States; in: Teresa Ter-Minassian (ed.): Fiscal Federalism in Theory and Practice, Washington (International Monetary Fund): 359. 383.

Stuart, John 1997: Efficiency in the South African Public Sector: Fundamental Issues and Lessons, Discussion Paper No. 17 (October), Cape Town (University of Cape Town: Budget Project).

Tanzi, Vito 1996: Fiscal Federalism and Decentralization: A Review of Some Efficiency and Macroeconomic Aspects; in: Michael Bruno and Boris Pleskovic (eds): Annual World Bank Conference on Development Economics 1995, Washington D.C. (World Bank): 295-316.

Tapscott, Chris 1996: The Institutionalisation of Rural Local Government in PostApartheid South Africa; in: Konrad Adenauer Foundation Occasional Paper (November), Johannesburg (Konrad Adenauer Foundation): 13-22. 
Tapscott, Chris 1998: Intergovernmental Relations in South Africa - A Comparative Analysis; in: Department of Constitutional Development and Provincial Affairs (ed.): Intergovernmental Relations. An International Comparative Study, Pretoria: 9-28.

Ter-Minassian, Teresa (ed.) 1997a: Fiscal Federalism in Theory and Practice, Washington (International Monetary Fund).

Ter-Minassian, Teresa 1997b: Brazil; in: Teresa Ter-Minassian (ed.): Fiscal Federalism in Theory and Practice, Washington (International Monetary Fund): 438-457.

Ter-Minassian, Teresa and Jon Craig 1997: Control of Sub-National Government Borrowing; in: Teresa Ter-Minassian (ed.): Fiscal Federalism in Theory and Practice, Washington (International Monetary Fund): 156-172.

Urban Foundation (Development Strategy and Policy Unit) 1993: Development and Democracy: The Regional Question, 5 July, Johannesburg (Urban Foundation).

Van den Heever, Alex 1998: Conditional Grants for Health: With a Special Emphasis on the Central Hospital and Teaching and Research Grants (draft report submitted to the Financial and Fiscal Commission).

Van der Merwe, Fanus and Larette Jansen van Rensburg 1998: An Overview of the 1998/99 Northwest Province Budget, Cape Town (Idasa: Budget Information Service).

Van Heerden, Reinett 1997: Lack of skills hampers NCOP; in: Privincial Whip, 11 August: 2.

Van Niekerk, Phillip and Barbara Ludman (eds) 1999: Mail \& Guardian A-Z of South African Politics 1999. The Essential Handbook, Sandton (Penguin Books).

Van Zyl, Albert 1998a: Eastern Cape lessons. Can provinces stick to budgets?; in: Budget Watch Vol. 4 Issue 1 (May): 3. 
Van Zyl, Albert 1998b: An Overview of the 1998/99 Western Cape Provincial Budget, Cape Town (Idasa: Budget Information Service).

Van Zyl, Albert 1998c: An Overview of the 1998/99 Gauteng Provincial Budget, Cape Town (Idasa: Budget Information Service).

Van Zyl, Albert 1998d: An Overview of the 1998/99 Mpumalanga Provincial Budget, Cape Town (Idasa: Budget Information Service).

Verney, Douglas V. 1995: Federalism, Federative Systems, and Federations: The United States, Canada, and India; in: Publius Vol. 25 No. 2: 81-97.

Walker, Laura 1998: An Overview of the 1998/99 KwaZulu-Natal Provincial Budget, Cape Town (Idasa: Budget Information Service).

Walker, Laura 1999: Spend \& Deliver: Review of the Budget 1998/99 - 2001/02, Cape Town (Idasa: Budget Information Service).

Walker, Laura and Albert van Zyl 1999: Juggling central control and provincial fiscal autonomy in South Africa; in: Development Southerm Africa Vol. 16 No 2: 239-258.

Watts, Ronald L. 1990: Executive Federalism: A Comparative Analysis, Research Paper No. 26, Kingston / Ontario (Queen's University: Institute of Intergovernmental Relations).

Watts, Ronald L. 1997: Co-operative Government and Intergovernmental Relations: A Comparative Perspective (notes for a presentation at the special meeting of intergovernmental coordinators, 22 May, Cape Town).

Wehner, Joachim 1997a: Resolving the uneven distribution of wealth among provinces; in: Budget Watch Vol. 3 Issue 3 (September): 4-5.

Wehner, Joachim 1997b: Is NCOP just a rubber stamp?; in: Parliamentary Whip, 5 November: 6 . 
Wehner, Joachim 1997c: Finance proposals must be made accessible; in: Local Government Chronicle (SA), 21 November: 9.

Wehner, Joachim 1998a: Financing Local Government - A Comparative Perspective: Can South Africa Benefit from International Experience?, Discussion Paper No. 24 (February), Cape Town (University of Cape Town: Budget Project).

Wehner, Joachim 1998b: What is the Future of South Africa's Provinces?, Discussion Paper No. 29 (August), Cape Town (University of Cape Town: Applied Fiscal Research Centre).

Wehner, Joachim 1999a: Asymmetrical Devolution: An Outline, Discussion Paper No. 34 (March), Cape Town (University of Cape Town: Applied Fiscal Research Centre).

Wehner, Joachim 1999b: Parliament helps to redraft financial management framework; in: Budget Watch (June): 11.

Welsh, David 1994: The Provincial Boundary Demarcation Process; in: Bertus de Villiers (ed.): Birth of a Constitution, Kenwyn (Juta): 223-229.

Wheare, Kenneth C. 1946 (reissued edition, 1964): Federal Govermment, Oxford (Oxford University Press).

Williams, Colin H. 1995: A Requiem for Canada?; in: Graham Smith (ed.): Federalism: The Multiethnic Challenge, New York (Longman Publishing): 31-72.

Wiltshire, Kenneth 1989: Federal State / Provincial Financial Relations; in: Bruce W. Hodgins et al (eds): Federalism in Canada and Australia. Historical Perppectives 1920-88, Peterborough / Canada (Frost Centre for Canadian Heritage and Development Studies): 181199.

Wise, Charles 1998: Judicial Federalism: The Resurgence of the Supreme Court's Role in the Protection of State Sovereignty; in: Public Administration Review Vol. 58 No. 2: 95-98. 
Wolman, Harold 1990: Decentralization: What It Is and Why We Should Care; in: Robert J. Bennett (ed.): Decentralization, Local Govermments, and Markets. Towards a Post-Welfare Agenda, Oxford (Clarendon Press): 29-41.

\section{b) South African Legislation}

Borrowing Powvers of Provincial Governments Act, 1996 (Act 48 of 1996).

Constitution of the Republic of South Africa, 1996 [Final Constitution] (Act 108 of 1996).

Constitution of the Republic of South Africa, 1993 [nterim Constitution] (Act 200 of 1993).

Division of Revenue Act, 1998 (Act 28 of 1998).

Financial and Fiscal Commission Act, 1997 (Act 99 of 1997).

Intengovernmental Fiscal Relations Act, 1997 (Act 97 of 1997).

Public Finance Management Act, 1999 (Act 1 of 1999).

\section{c) Judgements of the Constitutional Court of South Africa}

Certification of the Constitution of the Republic of South Africa, 1996 [Certification Judgement $]$, 1996 (4) SA 744 (CC).

Certification of the Amended Text of the Constitution of the Republic of South Africa, 1996 [Certification Judgement II], 1997 (1) BCLR 1 (CC).

Certification of the Constitution of the Province of KwaZulu-Natal, 1996, 1996 (11) BCLR 1419 (CC). 
Certification of the Constitution of the Western Cape, 1997, 1997 (4) SA 794 (CC); 1997 (9) BCLR 1167 (CC).

\section{d) Referenced Constitutions of Other Countries}

Brazil: Constitution of the Federal Republic of Brazil, 1988.

Canada: Constitution Act, 1982.

Germany: Basic Law for the Federal Republic of Germany, 1949.

India: Constitution of India, 1950.

\section{e) Referenced Newspapers and Magazines}

Business Day (South Africa).

Cape Argus (South Africa).

Daily Telegraph (United Kingdom).

Der Spiegel (Germany).

Economic Times (India).

Economist (United Kingdom).

Financial Mail (South Africa).

Hindu (India).

Mail \&o Guardian (South Africa). 
Sowetan (South Africa).

Sunday Independent (South Africa).

\section{f) Interviews and Discussions}

Abdullah, Dr. Fareed (Department of Health, Westem Cape, Chief Director: Health Care), 17 June 1998.

Donian, Colin (Financial and Fiscal Commission, Research Co-ordinator), 8 April 1999.

Engela, Ronette (Department of Constitutional Affairs, Acting Director: Provincial Affairs), 9 April 1999.

Essop, Tasneem (Member of the Western Cape Provincial Legislature, African National Congress Spokesperson on Finance), 18 May 1998.

Friedman, Joel (Department of Finance, Senior Manager: Provincial Budget Analysis), 9 June 1998.

Momoniat, Ismail (Department of Finance, Chief Director: Intergovernmental Finance), 10 June 1998.

Neumann, Ron (Department of Finance, Manitoba, Canada, Director: Intergovernmental Finance), 9 April 1999.

Rich, Guy (Heath Special Investigaating Unit, Personal Assistant to Judge Willem Heath) and Gerhard Visagie (Heath Special Investigating Unit, Executive Manager: Legal Services), 29 March 1999.

Van Niekerk, Adriaan (Member of Parliament, National Council of Provinces, National Party Delegate for the Northern Cape), 8 October 1997. 
Woods, Dr. Gavin (Member of Parliament, National Assembly, Inkatha Freedom Party Spokesperson on Finance), 9 June 1998.

\section{g) Useful Internet Resources}

African National Congress (ANC): http://www.anc.org.za

Business Day: http://www.bday.co.za

Department of Finance: http://www. finance.gov.za

Heath Special Investigating Unit: http://www.heathsiu.co.za

Institute for Democracy in South Africa (Idasa): http://www.idasa.org.za

Library of Congress: http://www.loc.gov

Mail \& Guardian: http://www.mg.co.za

South African Constitutional Assembly: http://www.constitution.org.za

South African Government: http://www.polity.org.za

Statistics South Africa. http://www.statssa.gov.za 